\title{
5. SITE 306: SHATSKY RISE
}

\author{
The Shipboard Scientific Party ${ }^{1}$
}

\section{SITE DATA}

Date Occupied: 3 September 1973 (2315)

Date Departed: 8 September 1973 (0902)

Time on Site: 105 hours

Position: $31^{\circ} 52.02^{\prime} \mathrm{N}, 157^{\circ} 28.71^{\prime} \mathrm{E}$

Water Depth: 3399 corrected meters (echo sounding)

Bottom Felt With Drill Pipe At: 3416 meters

Penetration: 475 meters below rig floor

Number of Holes: 1

Number of Cores: 42

Total Length of Cored Section: 380.5 meters

Total Core Recovered: 27.3 meters

\section{BACKGROUND AND OBJECTIVES}

We were forced to abandon Site 305 near the crest of Shatsky Rise when the bit wore out at a total depth of 640 meters, of which about two-thirds was cherty. The lowest interval above acoustic basement was not penetrated. The interval is transparent on seismic reflection profiles and presumably would be easy to penetrate once any drilling had reached it. We decided therefore to select a site on the southwest flank of Shatsky Rise (Figure 1) where seismic records of other expeditions had shown that the opaque units, through which we had drilled at Site 305 , were relatively thin but the lower transparent layer remained as thick as at Site 305.

Our objectives at Site 306 were the ones unfulfilled at Site 305 , namely, to complete continuously coring through the sedimentary section and into basement. The specific objectives are listed in the preceding chapter (Site 305) and include the recovery of Lower Cretaceous and Upper to Middle? Jurassic rocks for biostratigraphic purposes, recovery of basement rocks to compare with basement of other rises, and samples for paleooceanographic and diagenetic studies. Furthermore, because the recovery of fossiliferous noncherty sediment was very poor in the Cretaceous part of Site

'Roger L. Larson, Lamont-Doherty Geological Observatory, Palisades, New York (Co-chief scientist); Ralph Moberly, Hawaii Institute of Geophysics, Honolulu, Hawaii (Co-chief scientist); David Bukry, U.S. Geological Survey, La Jolla, California; Helen P. Foreman, Oberlin College, Oberlin, Ohio; James V. Gardner, Scripps Institution of Oceanography, La Jolla, California; John B. Keene, Scripps Institution of Oceanography, La Jolla, California; Yves Lancelot, Lamont-Doherty Geological Observatory, Palisades, New York; Hanspeter Luterbacher, Esso Production Research-European, Begles, France; Monte C. Marshall, U. S. Geological Survey, Menlo Park, California; Albert Matter, Universitat Bern, Bern, Switzerland.

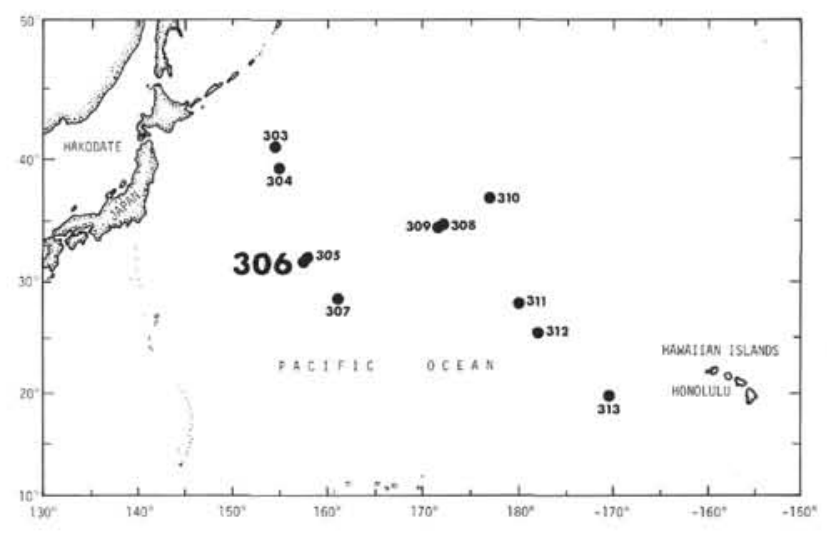

305 , we hoped that the part of the section we will have to core through again in order to reach the lower transparent layer and the basement would provide additional samples of Cretaceous fossils.

\section{OPERATIONS}

After wearing out a bit in the lower part of the section at the crest of Shatsky Rise (Site 305), we chose another site to sample the remainder of the section on the flank of the rise (Figures 2 and 3). Site 306 is $37 \mathrm{~km}$ westsouthwest of Site 305 in slightly deeper water where the upper layers of the section were greatly thinned or removed, and the lower portion was still present at its usual thickness. The site is located at the convergence of tracks from Vema-2110, Conrad-1007, and Scan-3. We approached Site 306 heading west-southwest which yielded a profile (Figure 4) showing first the uppermost semitransparent layer pinching out, then a "rough ground" area where the uppermost hard reflector outcrops, then an exposed section of semitransparent material beneath the reflector outcrop, and finally the outcrop of the second hard reflector. We chose our site between the outcrops of the two reflectors, steamed across it, reversed course, approached the site heading east-northeast and dropped the beacon at 5 knots at $1311 \mathrm{Z}$ on 3 September 1973 in 1817 uncorrected $\mathrm{fm}(=$ $3409 \mathrm{~m}$ corrected to the rig floor). At about $1400 \mathrm{Z}$ we began to run in pipe.

No sonobuoy was run at Site 306 due to the surrounding irregular topography and a lack of current.

We left this site steaming slowly to the northwest, streaming the running gear, turning and coming back across the beacon headed southeast enroute to Site 307 . This route provided a profile (Figure 4) that shows our location on a bench above very irregular topography and a steep scarp that forms the transition from Site 306 to the deep sea floor. 


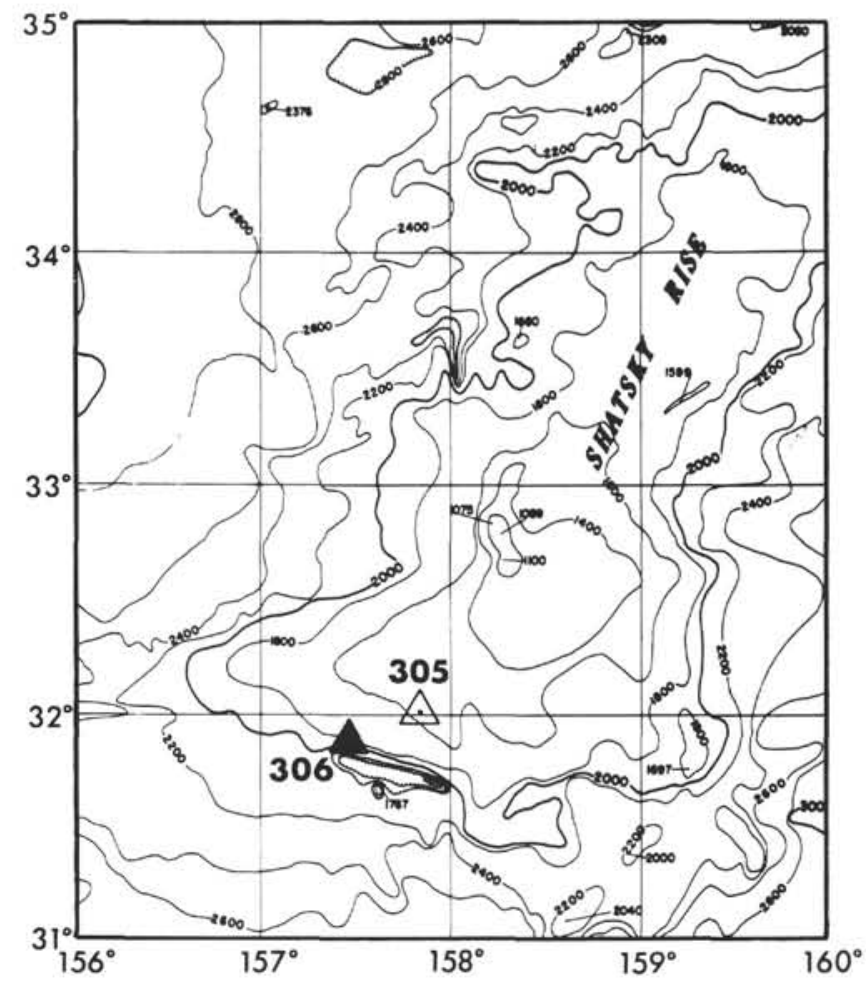

Figure 1. Bathymetry in the region of Sites 305 and 306 (after Chase et al., 1971). Contour interval $200 \mathrm{fm}$ uncorrected.

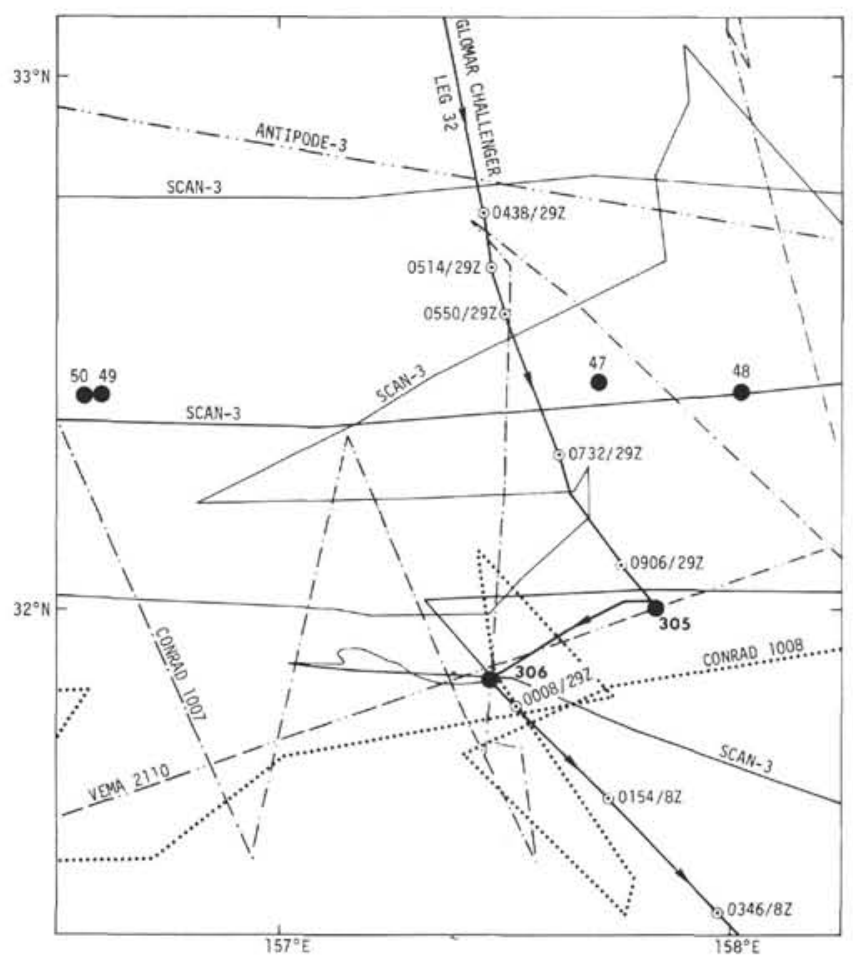

Figure 2. Track chart for Sites 305 and 306. Heavy solid track is Leg 32 Glomar Challenger; dotted track is Conrad 1008; dash-dot-dot track is Vema 2110; dash-dot track is Conrad 1007; and light solid track is Scan-3. DSDP drill sites indicated by solid circles.

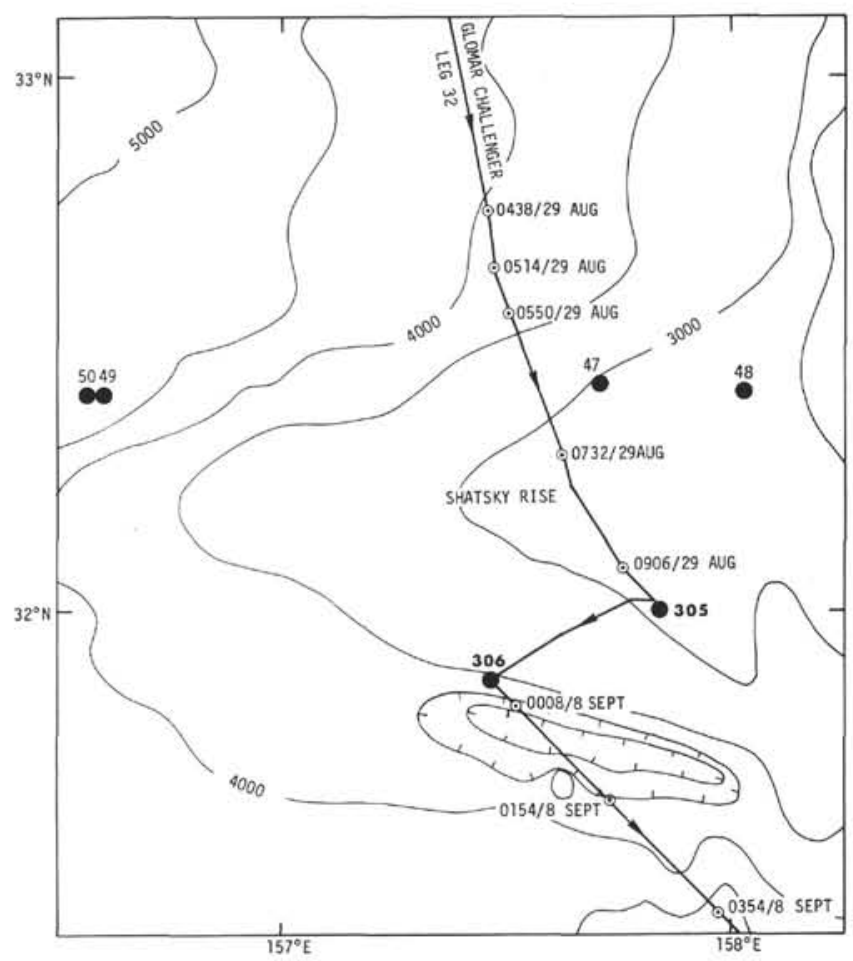

Figure 3. Bathymetry of Sites 305 and 306. Contours in corrected meters interpolated from Chase et al. (1971). Solid line marks track of Leg 32 Glomar Challenger and open circles mark navigation points with time/day-month.

A hard sea floor was encountered at 3416 meters. Rotation and circulation for $2 \mathrm{hr}$ and $25 \mathrm{~min}$ were required to cut the first core that consisted of chert and turbidite debris ranging in age from Recent to Albian. Stiff Cretaceous sediments and interbedded cherts continued to be encountered that required about $24 \mathrm{hr}$ to bury the bottom hole assembly. Throughout this period the wind speed was usually $25-30$ knots with gusts to $35-$ 40 knots during squalls that periodically buffeted the ship. A combination of constant expert attention by the drillers and precise positioning from the bridge was necessary to save the site and the bottom-hole assembly. From 28 to 207.5 meters (subbottom depth) we alternated coring one interval and drilling the next, first to bury the bottom-hole assembly as soon as possible and then to save time reaching the stratigraphic level of the bottom of Site 305 .

Recovery was poor throughout Site 306 except in Cores $1,20,21,22,40,41$, and 42 because of the ubiquitous cherts present throughout the section. An attempt was made to improve recovery by dry drilling Core 31 for 2 meters. Subsequently, a flapper-type catcher was used in place of the usual soft-formation catcher. Neither attempt improved recovery. We drilled nearly the entire hole with circulation that was necessary to keep from sticking the drill string or plugging the bit with chert cuttings. Occasionally very hard sections of chert, such as Core 35 , were encountered that required about $2 \mathrm{hr}$ to cut.

For core recovery at this site, the alternate sand line and winch, mounted above the draw-works, were used 


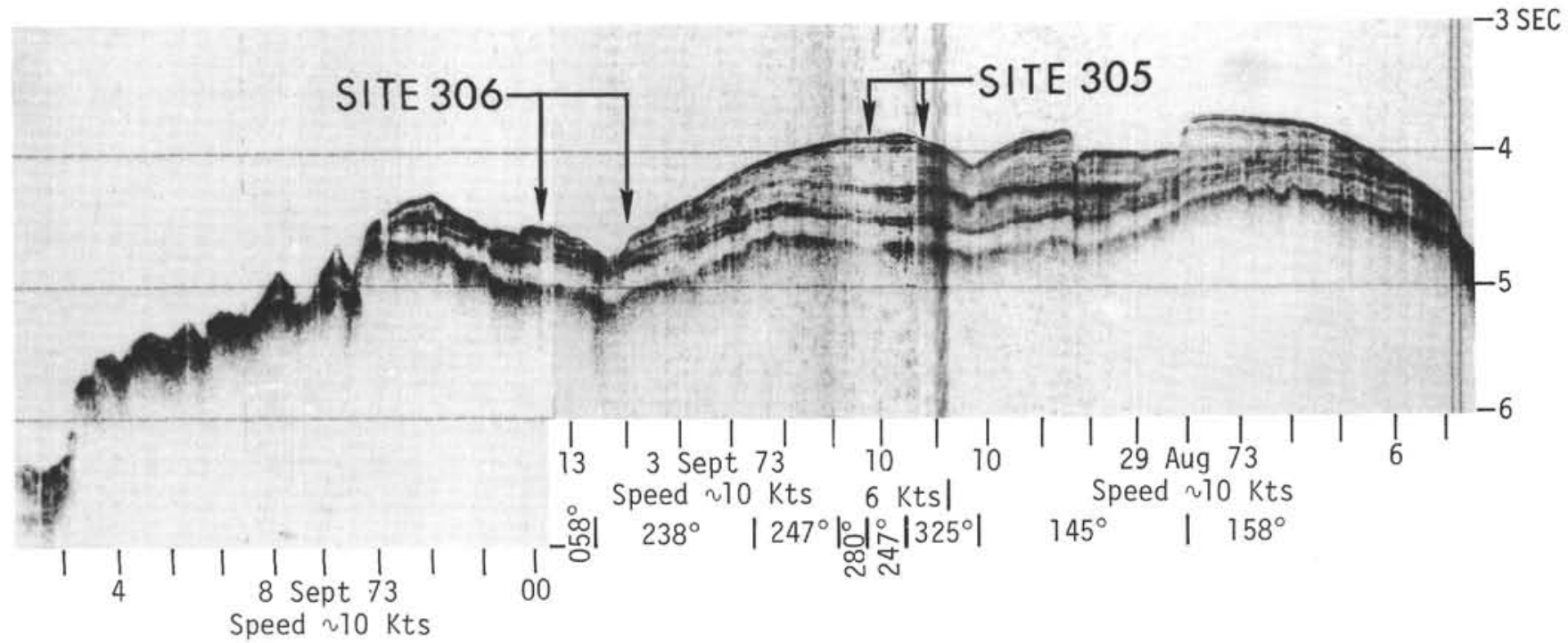

Figure 4. Seismic profiler section approaching and leaving Sites 305 and 306.

because the strands of wire in the regular sand line had unlayed. Operation of the alternate winch is not as smooth as that of the regular one, and an attempt was made to cut out the faulty section of sand line and splice it enroute to Site 307.

The drill string began to torque badly on Core 42 . During the attempt to cut a 43rd core, the drill string would not rotate when large torques were applied, and there was no penetration at all. We abandoned the site at 475 meters total depth (bottom of Core 42). The bit recovered (Figure 5) was in even worse shape than the bit at Site 305. All four cones were missing, two shanks were torn off, and the circulation vents were partially plugged with abraded metal. The bit had, however, rotated in cherty sediment about $10 \mathrm{hr}$ longer than had any other bit used by the Deep Sea Drilling Project. The coring at Site 306 is summarized in Table 1.

\section{LITHOLOGIC SUMMARY}

Drilling at Site 306 terminated in nanno chalks and cherts of Tithonian age at a depth of 475 meters. The section was alternately cored and washed at about 9 meter intervals from 28 to 207.5 meters and then continuously cored to 475 meters. The sedimentary section was incompletely sampled. Poor recovery was caused by lithified cherts alternating with less-consolidated oozes and chalks.

The relative portions of the various rock types encountered is biased in favor of the hard cherts, the softer sediments being preferentially ground up and washed away during drilling.

The smear slide composition of the sediments is shown in the smear slide summary (Table 2). No smear slides could be prepared from lithified porcellanites and from cherts, therefore their composition does not appear in the smear slide summary. The composition and textures of these rocks were examined ashore in thin sections and by X-ray diffractometry.
The sedimentary sequence at Site 306 can be subdivided into the following lithologic units:

Unit 1 -Siliceous foram-bearing nanno ooze $(0-9.5$ $\mathrm{m}$, Core 1).

Unit 2-Foram-bearing nanno ooze, chalk and chert (9.5-66 m, Cores 2 to 5).

Unit 3-Calcareous porcellanite and chert (75.5-262.5 $\mathrm{m}$, Cores 6 to 18$)$.

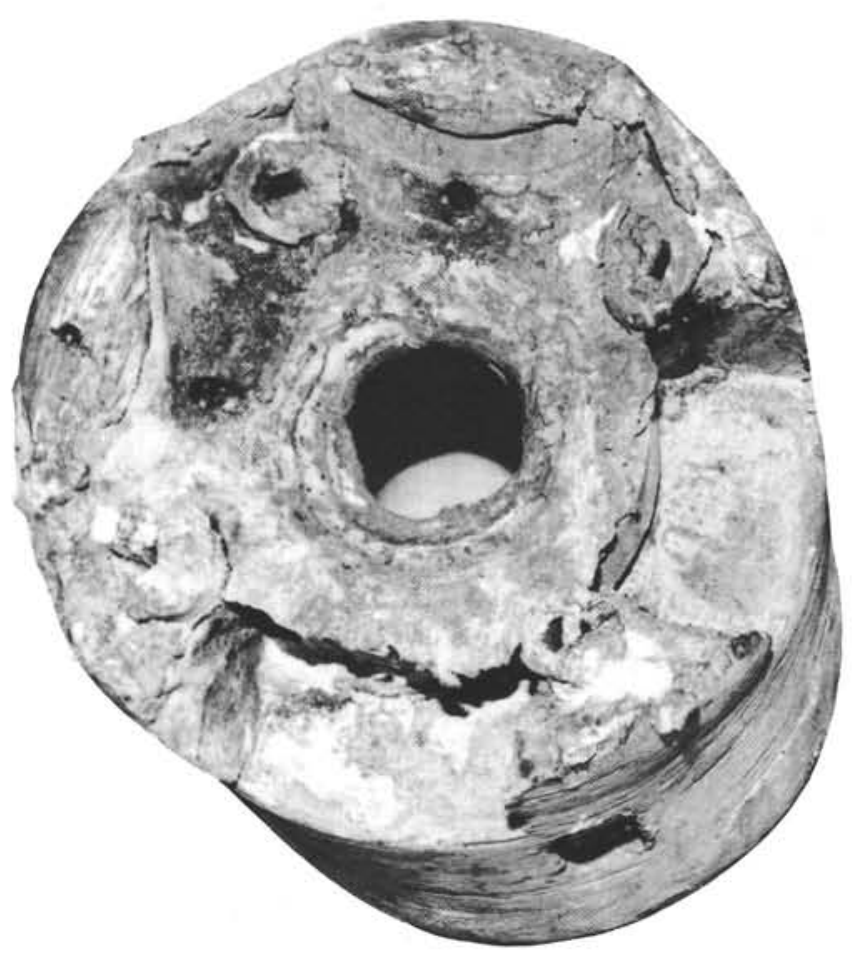

Figure 5. Drill bit recovered after termination of drilling at Site 306. Note that all four cones are missing. 
TABLE 1

Coring Summary

\begin{tabular}{|c|c|c|c|c|c|c|c|}
\hline Core & $\begin{array}{c}\text { Date } \\
\text { (Sept. 1973) }\end{array}$ & Time & $\begin{array}{l}\text { Depth From } \\
\text { Drill Floor } \\
(\mathrm{m})\end{array}$ & $\begin{array}{l}\text { Depth Below } \\
\text { Sea Floor } \\
(\mathrm{m})\end{array}$ & $\begin{array}{l}\text { Length } \\
\text { Cored } \\
\text { (m) }\end{array}$ & $\begin{array}{c}\text { Length } \\
\text { Recovered } \\
\text { (m) }\end{array}$ & $\begin{array}{c}\text { Recovery } \\
(\%)\end{array}$ \\
\hline 1 & 4 & 1050 & $3416.0-3425.5$ & $0.0-9.5$ & 9.5 & 8.9 & 94 \\
\hline 2 & 4 & 1400 & $3425.5-3435.0$ & $9.5-19.0$ & 9.5 & 0.1 & 1 \\
\hline 3 & 4 & 1615 & $3435.0-3444.0$ & $19.0-28.0$ & 9.0 & 0.2 & 2 \\
\hline 4 & 4 & 1915 & $3453.5-3463.0$ & $37.5-47.0$ & 9.5 & 0.3 & 3 \\
\hline 5 & 4 & 2100 & $3472.5-3482.0$ & $56.5-66.0$ & 9.5 & $\operatorname{tr}$ & $<1$ \\
\hline 6 & 4 & 2315 & $3491.5-3500.5$ & $75.5-84.5$ & 9.0 & 0.8 & 8 \\
\hline 7 & 5 & 0330 & $3510.0-3519.5$ & $94.0-103.5$ & 9.5 & 0.1 & 1 \\
\hline 8 & 5 & 0650 & $3529.0-3538.5$ & $113.0-122.5$ & 9.5 & 1.7 & 18 \\
\hline 9 & 5 & 0950 & $3548.0-3557.5$ & $132.0-141.5$ & 9.5 & 1.7 & 18 \\
\hline 10 & 5 & 1240 & $3567.0-3576.5$ & $151.0-160.5$ & 9.5 & 1.1 & 12 \\
\hline 11 & 5 & 1450 & $3585.5-3595.0$ & $169.5-179.0$ & 9.5 & 1.0 & 11 \\
\hline 12 & 5 & 1815 & $3604.5-3614.0$ & $188.5-198.0$ & 9.5 & 1.3 & 14 \\
\hline 13 & 5 & 2115 & $3623.5-3633.0$ & $207.5-217.0$ & 9.5 & 0.1 & 1 \\
\hline 14 & 5 & 2320 & $3633.0-3642.0$ & $217.0-226.0$ & 9.0 & 0.1 & 1 \\
\hline 15 & 6 & 0025 & $3642.0-3651.0$ & $226.0-235.0$ & 9.0 & $\operatorname{tr}$ & $<1$ \\
\hline 16 & 6 & 0150 & $3651.0-3660.0$ & $235.0-244.0$ & 9.0 & 0.1 & 1 \\
\hline 17 & 6 & 0310 & $3660.0-3669.0$ & $244.0-253.0$ & 9.0 & 0.1 & 1 \\
\hline 18 & 6 & 0420 & $3669.0-3678.5$ & $253.0-262.5$ & 9.5 & 0.1 & 1 \\
\hline 19 & 6 & 0530 & $3678.5-3687.5$ & $262.5-271.5$ & 9.0 & $\operatorname{tr}$ & $<1$ \\
\hline 20 & 6 & 0645 & $3687.5-3697.0$ & $271.5-281.0$ & 9.5 & 2.4 & 25 \\
\hline 21 & 6 & 0805 & $3697.0-3706.5$ & $281.0-290.5$ & 9.5 & 1.3 & 14 \\
\hline 22 & 6 & 0930 & $3706.5-3716.0$ & $290.5-300.0$ & 9.5 & 0.9 & 9 \\
\hline 23 & 6 & 1150 & $3716.0-3725.0$ & $300.0-309.0$ & 9.0 & 0.1 & 1 \\
\hline 24 & 6 & 1310 & $3725.0-3734.5$ & $309.0-318.5$ & 9.5 & 0.5 & 5 \\
\hline 25 & 6 & 1410 & $3734.5-3743.5$ & $318.5-327.5$ & 9.0 & 0.1 & 1 \\
\hline 26 & 6 & 1515 & $3743.5-3753.0$ & $327.5-337.0$ & 9.5 & 0.2 & 2 \\
\hline 27 & 6 & 1610 & $3753.0-3762.5$ & $337.0-346.5$ & 9.5 & 0.0 & 0 \\
\hline 28 & 6 & 1745 & $3762.5-3771.5$ & $346.5-355.5$ & 9.0 & 0.2 & 2 \\
\hline 29 & 6 & 1920 & $3771.5-3781.0$ & $355.5-365.0$ & 9.5 & 0.1 & 1 \\
\hline 30 & 6 & 2055 & $3781.0-3790.5$ & $365.0-374.5$ & 9.5 & 0.2 & 2 \\
\hline 31 & 6 & 2235 & $3790.5-3792.5$ & $374.5-376.5$ & 2.0 & 0.0 & 0 \\
\hline 32 & 7 & 0020 & $3792.5-3800.0$ & $376.5-384.0$ & 7.5 & 0.1 & 1 \\
\hline 33 & 7 & 0215 & $3800.0-3809.0$ & $384.0-393.0$ & 9.0 & $\operatorname{tr}$ & $<1$ \\
\hline 34 & 7 & 0350 & $3809.0-3818.0$ & $393.0-402.0$ & 9.0 & tr & $<1$ \\
\hline 35 & 7 & 0640 & $3818.0-3827.5$ & $402.0-411.5$ & 9.5 & 0.2 & 2 \\
\hline 36 & 7 & 0825 & $3827.5-3837.0$ & $411.5-421.0$ & 9.5 & 0.2 & 2 \\
\hline 37 & 7 & 1000 & $3837.0-3846.5$ & $421.0-430.5$ & 9.5 & 0.2 & 2 \\
\hline 38 & 7 & 1155 & $3846.5-3856.0$ & $430.5-440.0$ & 9.5 & 0.2 & 2 \\
\hline 39 & 7 & 1345 & $3856.0-3865.5$ & $440.0-449.5$ & 9.5 & 0.1 & 1 \\
\hline 40 & 7 & 1550 & $3865.5-3875.0$ & $449.5-459.0$ & 9.5 & 0.7 & 7 \\
\hline 41 & 7 & 1930 & $3875.0-3883.5$ & $459.0-467.5$ & 8.5 & 1.3 & 15 \\
\hline 42 & 7 & 2210 & $3883.5-3891.0$ & $467.5-475.0$ & 7.5 & 0.6 & 8 \\
\hline Total & & & & & 380.5 & 27.3 & 7.2 \\
\hline
\end{tabular}

Unit 4-Nanno ooze, chalk, and chert $(262.5-475 \mathrm{~m}$, Cores 19 to 42 ).

\section{Unit 1-Siliceous Foram-bearing Nanno Ooze (Core 1)}

This unit comprises only the uppermost severely disturbed core which consists of soft volcanic glass-bearing nanno-foram ooze, foram-nanno ooze, and phillipsitebearing siliceous foram-nanno ooze, ranging in color from white to various shades of orange and brown.

The siliceous layers with total carbonate content between $60 \%$ and $70 \%$ (Table 3 ) consist of a few percent phillipsite and barite, about $20 \%$ foraminifera, $40 \%$ to $60 \%$ nannofossils, and $30 \%$ to $40 \%$ siliceous fossils, dominantly Radiolaria with lesser amounts of diatoms and silicoflagellates. The terrigenous component, generally less than $15 \%$, is made up of quartz, minor feldspar, and clay minerals.

The more calcareous layers without siliceous fossils contain about $80 \%$ carbonate and consist of varying proportions of foraminifera, nannofossils, and minor amounts of light and brown volcanic glass shards.

Pumice fragments up to $4 \mathrm{~cm}$ in size, small manganese nodules, and lumps of chalk and chert were also found.

Although the core was badly disturbed by drilling, two graded beds were recognized. The paleontologic data reveal a Quaternary age for the topmost few centimeters of the core and Cenozoic to Late Cretaceous ages for the chalk lumps. It is concluded that this material was derived by erosion from a nearby scarp, visible on the seismic records. The presence of graded beds also indicates resedimentation.

\section{Unit 2-Foram-bearing Radiolarian Nanno Ooze,} Chalk, and Chert (Cores 2 through 5)

The first appearance of chalk and chert is taken as a unit boundary at Site 306, as was done at Site 305 .

Since only core-catcher samples were retrieved from Unit 2, the structural relationships of the lithologies are 
TABLE 2

Smear Slide Summary, Site 306

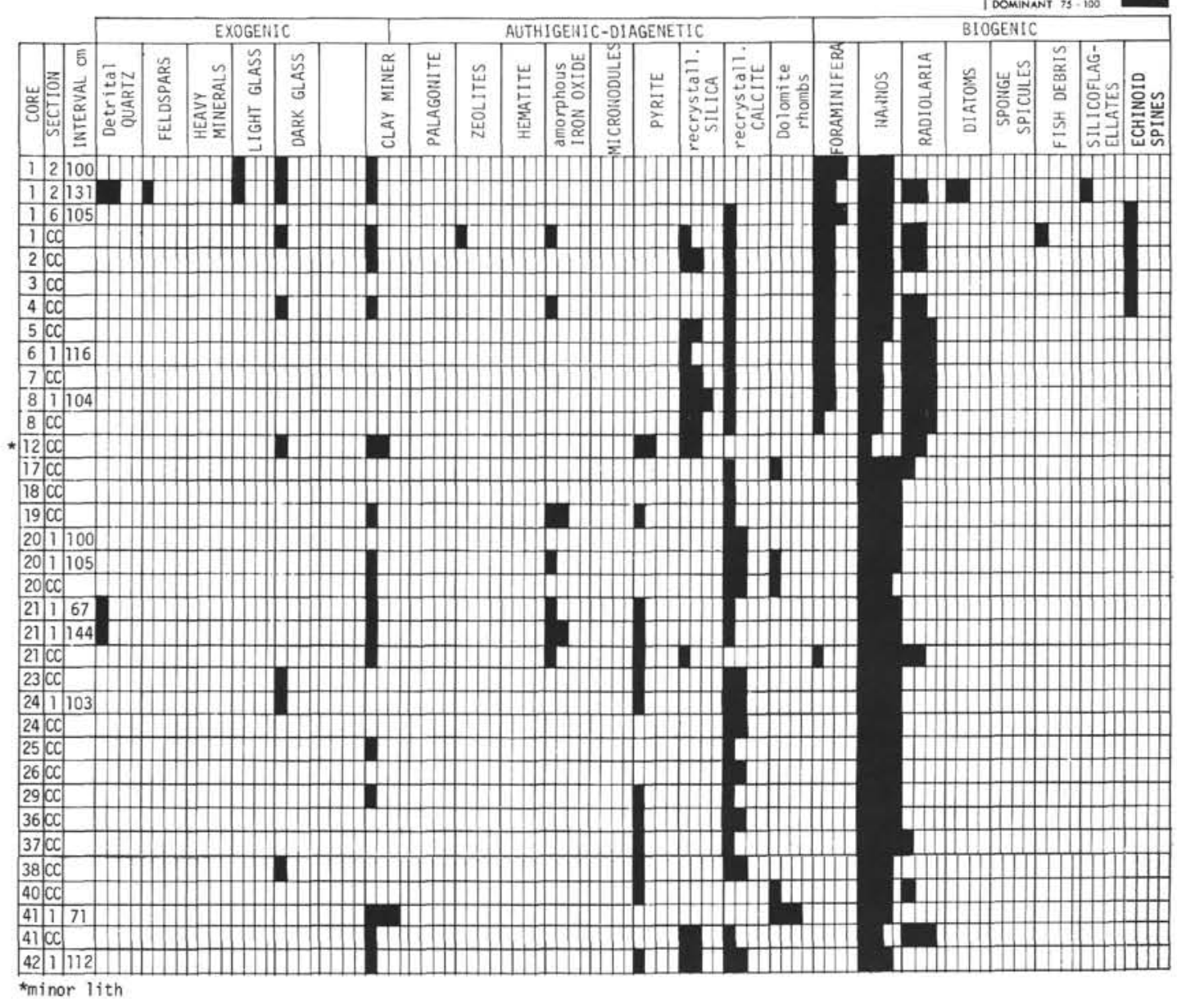


TABLE 3

Additional Carbon-Carbonate Data

\begin{tabular}{|c|c|c|}
\hline $\begin{array}{c}\text { Sample } \\
\text { (Interval } \\
\text { in } \mathrm{cm} \text { ) }\end{array}$ & $\begin{array}{l}\text { Hole Depth } \\
\text { (m) }\end{array}$ & ${ }_{(\%)}^{\mathrm{CaCO}_{3}}$ \\
\hline $1, \mathrm{CC}$ & 9.5 & 62 \\
\hline $2, \mathrm{CC}$ & 19.0 & 57 \\
\hline $5, \mathrm{CC}$ & 66.0 & 62 \\
\hline $6-1,114$ & 76.64 & 42 \\
\hline $10-1,69$ & 151.69 & 32 \\
\hline $11, C C \# 1$ & 179.0 & 24 \\
\hline $11, C C \# 2$ & 179.0 & 0 \\
\hline $12, \mathrm{CC} \# 2$ & 198.0 & 14 \\
\hline $14, \mathrm{CC} \# 2$ & 226.0 & 27 \\
\hline $21-1,62$ & 281.62 & 87 \\
\hline $21-1,142$ & 282.42 & 79 \\
\hline $22-1,106$ & 291.56 & 76 \\
\hline $24-1,140$ & 310.40 & 96 \\
\hline $25, \mathrm{CC}$ & 327.5 & 93 \\
\hline $26, \mathrm{CC}$ & 337.0 & 94 \\
\hline $29, \mathrm{CC}$ & 365.0 & 82 \\
\hline $36, \mathrm{CC}$ & 421.0 & 90 \\
\hline $37, \mathrm{CC}$ & 430.5 & 96 \\
\hline $38, \mathrm{CC}$ & 440.0 & 93 \\
\hline $40-1,95$ & 450.45 & 42 \\
\hline $40, \mathrm{CC}$ & 459.0 & 80 \\
\hline $41-1,71$ & 459.71 & 70 \\
\hline $41, \mathrm{CC}$ & 467.5 & 77 \\
\hline
\end{tabular}

unknown. The following sediment types were observed: white, faintly laminated foram-bearing radiolarian nanno ooze, chalk, and chert.

The white ooze and chalk are made up of $10 \%$ to $20 \%$ foraminifera, $10 \%$ to $30 \%$ Radiolaria, $35 \%$ to $60 \%$ nannofossils, minor amounts of recrystallized carbonate and recrystallized silica particles, and rare phillipsite crystals, echinoid spines, and clay minerals (Table 2).

The chert, occurring as irregularly shaped masses and thin layers of small lateral extension, is vitreous, conchoidally fractured, and commonly contains blebs and stringers of partly silicified chalk. The boundary between chert and chalk appears sharp; however, a lesssilicified transition zone a few millimeters thick is frequently observed. Equant quartz and chalcedony are the dominant silica types in the chert, but the matrix in the transitional zone consists mainly of disordered cristobalite and calcitic nannofossils. The same observation was made earlier by Lancelot (1973).

Chert fragments of various colors, but dominantly ofi different shades of brown and gray, were observed. Mottling with lighter tones of the dom nant color is common.

Lithologically, Unit 2 at Site 306 corresponds to the lower part of Unit 3 at Site 305. However, based on paleontologic data, these units are not exactly time equivalent.

\section{Unit 3-Calcareous Porcellanite and Chert (Cores 6 through 18)}

Unit 3 consists almost entirely of lithified, porous, more or less calcareous porcellanite, and chert. Due to fair recovery in the upper part of this unit, the structural relationships of the porcellanite and chert could be examined.
Chert is found as irregularly shaped to anastomosing nodules of various sizes ranging from $1 \mathrm{~mm}$ to more than the core diameter, and as blebs and small stringers in the porcellanite. The dominant colors of the chert are various shades of brown and black to greenish-gray. Mottling with lighter shades is common. White, partly silicified chalk occurs as inclusions and as lining of vugs of various sizes up to $2 \mathrm{~cm}$ in diameter.

The only form of silica found in the true, vitreous cherts is quartz. It occurs as equant microcrystalline grains about 1 to $2 \mu \mathrm{m}$ across with interlocking boundaries and undulose extinction. It appears therefore that much of the microcrystalline quartz matrix is chalcedony. Larger quartz grains, definitely fibrous chalcedony, are seen in former radiolarian molds. However, most of the Radiolaria are barely visible as "ghosts" in the microcrystalline matrix. Inclusions of calcite particles are always found in small amounts. The color of the brown chert is caused by numerous ferroan-oxide particles.

Various types of more or less calcareous porcellanites were found. They grade from white, faintly laminated calcareous porcellanites, which are still close to a radiolarian nanno limestone, to distinctly laminated dark to light gray types which contain abundant clay minerals. The carbonate content varies from about $45 \%$ in the white porcellanites to zero in the medium to dark gray ones. Radiolaria are common to abundant, foraminifera are rare.

All of the X-rayed porcellanites showed quartz and opal-CT (Jones and Segnit, 1971). Most of the quartz is present as fibrous chalcedony filling the radiolarian molds, whereas most of the opal-CT is found in the silica matrix replacing the nannofossils. This matrix is a microcrystalline aggregate of disordered cristobalite (opal-CT) and quartz. Acid treatment described earlier by Heath and Moberly (1971) reveals a spongy framework in the carbonate-bearing porcellanites formed by the silica matrix and the radiolarians.

Often the entire surface ornamentation of Radiolaria is retained although quartz may fill the interior of the test (compare Heath and Moberly, 1971, fig. 13). Between this state and the condition where only clear chalcedony fibers fill the Radiolaria, all transitional phases of decreasing amounts of cristobalite "inclusions" in chaldedony are observed.

In Core 13 a thin layer of black carbonaceous pelagic shale was found.

Lithologically, Unit 3 at Site 306 strongly resembles Unit 4 at Site 305 . However, porcellanites occur more commonly at Site 306. According to biostratigraphic data, the top of these units is diachronous. However, since the lithologic boundaries are gradational and are based on poorly recovered sections, the diachronous contact might be fortuitous.

\section{Unit 4-Nanno Ooze, Chalk, and Chert (Cores 19 through 42)}

Unit 4 is made up dominantly of nanno chalk with radiolarian chert nodules as interpreted from corecatcher samples. The minor amounts of soft nanno ooze could be nanno chalk homogenized by drilling.

The chalk is light gray to olive-gray with wavy lamination, commonly disrupted by moderate bioturba- 
tion. The chalk is composed mainly of nannofossils and recrystallized carbonate particles of nannofossil origin and minor amounts of foraminifera, dolomite rhombs, pyrite, and clay minerals. Radiolaria are abundant in Cores 40 to 42 .

Thin dark green layers in the chalk of Cores 41 and 42 are rich in celadonite and dolomite and contain some colored volcanic glass shards.

Chert is dominantly dark gray to grayish-black with mottling in light gray. Some cherts are dominantly brown with mottling and lamination in olive-black and greenish-gray. This type of chert, although showing pronounced conchoidal fracturing, lacks a bright vitreous luster and appears more like a porcellanite. It is characterized by anastomosing silicification by quartz (no cristoballite was discovered) which results in darker (carbonate poor) and lighter (carbonate rich) areas and layers that may consist of up to $80 \%$ largely biogenous carbonate. These carbonate-rich parts display the dull luster and higher porosity of porcellanites.

The irregular distribution of calcite and quartz is also responsible for the mottled, cauliflower-like structure of many of these cherts.

The cherts also contain curved fractures now filled with chalcedony and numerous vugs commonly filled with white chalk.

\section{GEOCHEMICAL MEASUREMENTS}

Due to poor core recovery and lithified sediments, only one interstitial water sample was taken from this site. The sample was from 6 meters below the sea floor. The $p \mathrm{H}$, alkalinity, and salinity for the sample are given in Table 4.

Table 5 gives the result of an analysis for calcium carbonate in a sample from Core 11 (170 m subbottom). The sample, a calcareous porcellanite, contained $25 \%$ $\mathrm{CaCO}_{3}$.

\section{PHYSICAL PROPERTIES}

\section{Wet Bulk Density and Porosity of Soft Sediments}

Since little, if any, undisturbed sediment was recovered at this site, wet bulk density measurements using the GRAPE were confined to Core 1, Sections 2 and 6 and Core 20, Section 2. The density of the mixed, foram nanno ooze (apparently slope-wash detritus) of Core 1 ranges from 1.6 to $1.7 \mathrm{~g} / \mathrm{cc}$. The density of the nanno ooze of Core 20 , which is probably a paste of chalk ground up by drilling, varies between 1.9 and 2.1 $\mathrm{g} / \mathrm{cc}$. A single syringe sample was taken, from Core 1, Section 2, and its density, $1.59 \mathrm{~g} / \mathrm{cc}$, agrees quite well with the GRAPE value $(1.55 \mathrm{~g} / \mathrm{cc})$. Using the syringe
TABLE 5

$\% \mathrm{CaCO}_{3}$ - "Carbonate Bomb" Method Shipboard Measurement

\begin{tabular}{|c|c|c|c|c|c|}
\hline Hole & Core & Section & Weight (g) & Pressure & $\begin{array}{c}\mathrm{CaCO}_{3} \\
(\%)\end{array}$ \\
\hline & 11 & $1(\# 14)$ & 0.99 & 0.45 & $25.0 \%$ \\
\hline Note: & $\mathrm{aCO}_{3}$ & andards: & $\begin{array}{l}0.94 \mathrm{~g} 99 \% \mathrm{Ca} \\
(\mathrm{kp} / \mathrm{cm}) \\
0.17 \mathrm{~g} 99 \% \mathrm{Ca} \\
(\mathrm{kp} / \mathrm{cm})\end{array}$ & $\begin{array}{l}\mathrm{O}_{3}=1.48 \\
\mathrm{O}_{3}=0.33\end{array}$ & $\begin{array}{l}\text { ressure } \\
\text { ressure }\end{array}$ \\
\hline
\end{tabular}

data and assuming that the wet bulk density variation is due to changes in porosity, the porosity in the foram nanno ooze of Core 1 is about $65 \%$, whereas the porosity in the nanno ooze of Core 20 is about $47 \%$.

\section{Velocity Measurements}

The compressional wave velocity, $V p$, of the various rock types recovered at this site was measured on a Hamilton frame. The $V p$ of the nanno chalk ranges from 1.7 to $3.0 \mathrm{~km} / \mathrm{sec}$. The $V p$ of the calcareous porcellanites ranges from 2.4 to $3.3 \mathrm{~km} / \mathrm{sec}$, whereas that of chert is 4.8 to $5.1 \mathrm{~km} / \mathrm{sec}$. These $V p$ values are quite similar to those measured at the previous sites of this leg. The velocities of both the siliceous and calcareous rocks increase with lithification. Beginning with a velocity of 1.5 $\mathrm{km} / \mathrm{sec}$ in the oozes, $V p$ increases to 2 to $3 \mathrm{~km} / \mathrm{sec}$ in the chalks, limestones, and porcellanites, and then jumps to $5 \mathrm{~km} / \mathrm{sec}$ in chert.

\section{CORRELATION OF SEISMIC REFLECTION PROFILES WITH DRILLING RESULTS}

The correlation between the "acoustic stratigraphy" and the stratigraphic section recovered from Site 306 is based mainly on the seismic profile recorded between Sites 305 and 306 (Figure 4). This record shows that Site 306 was "spudded in" below the first subbottom reflector recognized at Site 305 and which crops out on the sloping sea floor a few kilometers northeast of Site 306.

The correlation between the two sites is rather well established despite the poor recovery of sediment in the lower part of the section.

At Site 306 the reflector corresponding to the second reflector observed at Site 305 consists of a thick $(0.12$ sec) reflective zone and appears to be made of at least two distinct reflectors. The upper one at the top of the reflective zone lies at $0.11 \mathrm{sec}$ and the second one at about $0.18 \mathrm{sec}$ below the sea floor. This latter clearly correlates with the second reflector observed at $0.58 \mathrm{sec}$ at Site 305. It corresponds to the same lithological

TABLE 4

Summary of Shipboard Geochemical Data

\begin{tabular}{lcccccc}
\hline $\begin{array}{l}\text { Sample } \\
\text { (Interval } \\
\text { in cm) }\end{array}$ & $\begin{array}{c}\text { Depth Below } \\
\text { Sea Floor } \\
(\mathrm{m})\end{array}$ & $\begin{array}{c}\text { Punch- } \\
\text { in }\end{array}$ & $\begin{array}{c}\text { Flow- } \\
\text { through }\end{array}$ & $\begin{array}{c}\text { Alkalinity } \\
(\mathrm{meq} / \mathrm{kg})\end{array}$ & $\begin{array}{c}\text { Salinity } \\
(\%)\end{array}$ & $\begin{array}{c}\text { Remarks } \\
(\text { Combination } \\
\text { Electrode } p \mathrm{H})\end{array}$ \\
\hline $\begin{array}{l}\text { Refer to Site } \\
\text { 1-4,144-150 }\end{array}$ & $\begin{array}{c}\text { for Surface Seawater } \\
6\end{array}$ & 7.59 & 7.78 & 2.53 & 35.2 & 7.67 \\
\hline
\end{tabular}


change as at Site 305 , namely the top of the porcellanite, chert, and pelagic shale section.

Although the upper section is very rich in chert and appeared as hard to drill as the corresponding interval at Site 305 , the interval velocity is slightly lower (2.2 $\mathrm{km} / \mathrm{sec}$ ) at this site. This probably results from a lesser degree of compaction of the sediment due to shallower burial.

Basement has not been reached, therefore it is impossible to determine the interval velocity for the lowermost part of the sedimentary section. If we assume a range of velocities from 2.8 to 3.1 for this interval, the acoustic basement which is observed at $0.42 \mathrm{sec}$ below the sea floor might be at subbottom depths ranging from 540 to 570 meters. The lowermost core obtained at this site might therefore come from layers situated at 65 to 95 meters above the basement.

A summary of these correlations is given in Figure 6.

\section{BIOSTRATIGRAPHIC SUMMARY}

Most of 475-meter section penetrated at Site 306 is of Early Cretaceous age, with the exception of Core 1 (mixed assemblages of late Albian to Holocene age) (see Table 6). Cores 41 and 42 are considered early Berriasian.

The foraminifera of Cores 2 and 3 correspond fairly well to those of Cores 44 and 45 at Site 305.

Ages are assigned on the basis of coccoliths which occur throughout the entire section. Because of poor recovery, smear slides for coccoliths prepared from thin calcareous crusts scraped from the chert represent often the only possibility to obtain an age determination.

The attribution of the base of the section to the early Berriasian is based on coccoliths.

Planktonic foraminifera which could be attributed to definite zones were observed only in the uppermost 50 meters. The scattered and generally poor foraminiferal assemblages found below 50 meters are of little strati- graphic value and allow only very broad age assignments.

Radiolaria belonging to the Dictyomitra somphedia Zone are found in Cores 2 to 4, the Acaeniotyle umbilicata Zone in Cores 5 to 12, the Eucyrtis tenuis Zone in Cores 14 to 19, and the Sethocapsa trachyostraca Zone in Core 21. In Cores 13 to 20 the Radiolaria are generally poorly represented and commonly indeterminate, from 22 to 39 they are entirely absent. In contrast, the Radiolaria in Cores 40 to 42 are common to few, and moderate to well preserved and may be assigned to the Sphaerostylus lanecola Zone.

\section{Foraminifera}

Core 1 contains a mixture of late Albian to Recent foraminifera.

Cores 2 and 3 are attributed to the late Albian (or basal Cenomanian) (Rotalipora apenninica, $R$. evoluta).

The presence of Ticinella primula in Core 4 places this core in the early or middle Albian. The microfaunas of Cores 6 and 7 are too poorly preserved in order to assure the presence of representatives of the genus Ticinella. No planktonic foraminifera were found in place below Core 7.

The microfaunas from Cores 8 and 9 are very poor and uncharacteristic. No washed residues could be obtained from Cores 10 and 11 .

Core 12 contains the first specimens of Dorothia zedlerae. The interval corresponding to Cores 12 through 21 is attributed to the "interval between first occurrence of Dorothia zedlerae and first occurrence of Dorothia hauteriviana" (= Barremian to early Aptian). Only chert chips or caved microfaunas were recovered from Cores 13 to 18 . Cores 19 and 21 contain only poor and uncharacteristic microfaunas. In Core 20, representatives of the genus Spirillina are relatively common.

The first specimens of Dorothia hauteriviana are observed in Core 22, whereas the last representatives of

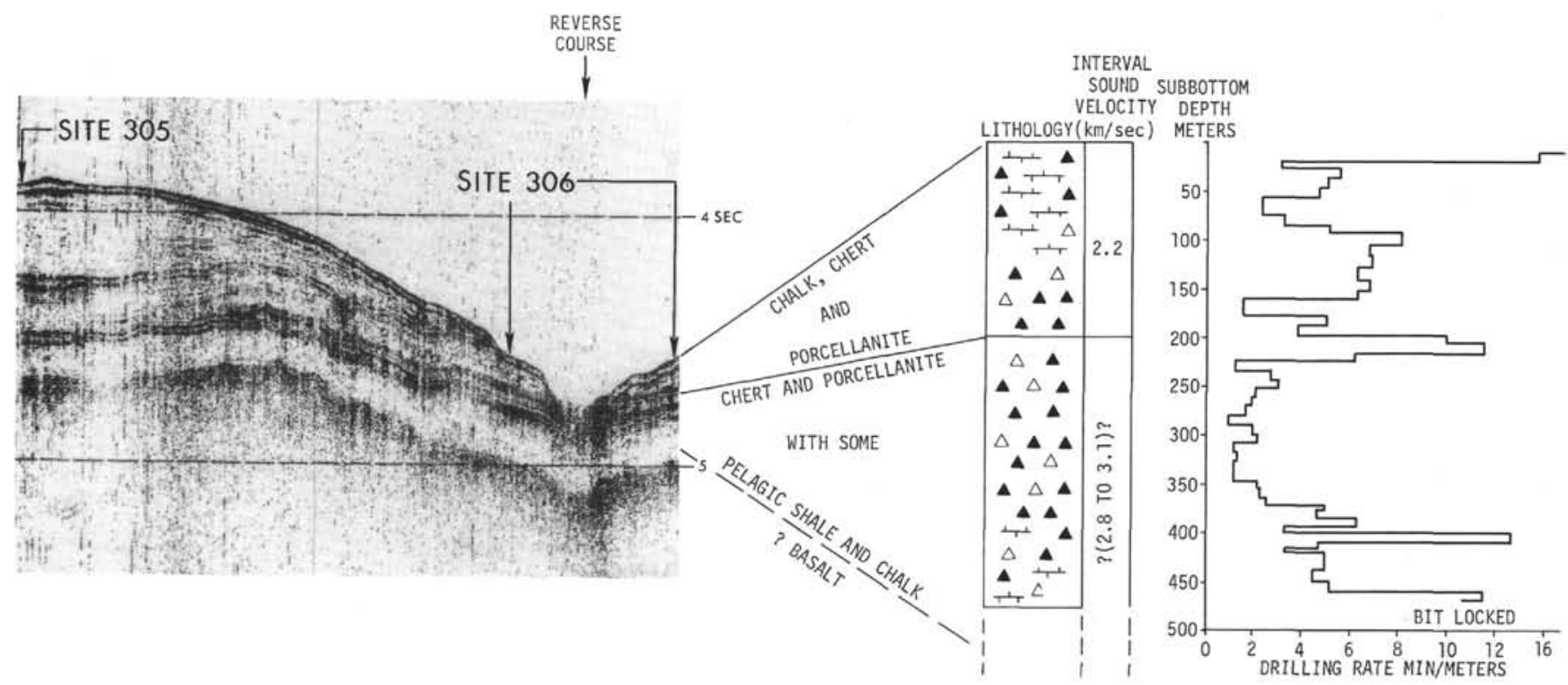

Figure 6. Correlation of seismic reflection profile with drilling results at Site 306. 
TABLE 6

Distribution, Age, and Frequency of Investigated Microfossils

\begin{tabular}{|c|c|c|c|c|c|c|c|c|c|}
\hline \multirow{2}{*}{ ن } & \multirow[b]{2}{*}{ Depth $(\mathrm{m})$} & \multirow{2}{*}{ 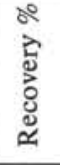 } & \multicolumn{3}{|c|}{ Foraminifera } & \multirow{2}{*}{\multicolumn{2}{|c|}{$\begin{array}{c}\text { Calcareous } \\
\text { Nannoplankton }\end{array}$}} & \multirow{2}{*}{\multicolumn{2}{|c|}{ Radiolaria }} \\
\hline & & & $\frac{\pi}{2 \pi}$ & 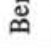 & & & & & \\
\hline 1 & $0.0-9.5$ & 94 & $\bullet$ & + & $\begin{array}{l}\text { Mixed Quaternary/ } \\
\text { late Albian }\end{array}$ & $\bullet$ & Quaternary & + & Late Pleistocene \\
\hline 2 & $9.5-19.0$ & 1 & $*$ & + & Late Albian & 0 & $\begin{array}{l}\text { Early Cenomanian/ } \\
\text { late Albian }\end{array}$ & * & - \\
\hline 3 & $19.0-28.0$ & 2 & $*$ & + & Late Albian & $\bullet$ & $\begin{array}{l}\text { Early Cenomanian/ } \\
\text { late Albian }\end{array}$ & * & - \\
\hline 4 & $37.5-47.0$ & 3 & $*$ & + & Albian & o & Late Albian & $*$ & - \\
\hline 5 & $56.5-66.0$ & $<1$ & + & + & - & o & Late Albian & 0 & \\
\hline 6 & $75.5-84.5$ & 8 & + & + & Albian (?) & o & $\begin{array}{l}\text { Early Albian/ } \\
\text { late Aptian }\end{array}$ & o & - \\
\hline 7 & $94.0-103.5$ & 1 & + & + & Albian (?) & $\bullet$ & $\begin{array}{l}\text { Early Albian/ } \\
\text { late Aptian }\end{array}$ & o & - \\
\hline 8 & $113.0-122.5$ & 18 & - & + & - & $\bullet$ & $\begin{array}{l}\text { Early Albian/ } \\
\text { late Aptian }\end{array}$ & o & - \\
\hline 9 & $132.0-141.5$ & 18 & - & + & - & $\bullet$ & $\begin{array}{l}\text { Early Aptian/ } \\
\text { Barremian }\end{array}$ & o & - \\
\hline 10 & $151.0-160.5$ & 12 & - & - & - & $\bullet$ & $\begin{array}{l}\text { Early Aptian/ } \\
\text { Barremian }\end{array}$ & o & - \\
\hline 11 & $169.5-179.0$ & 11 & - & - & - & o & $\begin{array}{l}\text { Early Aptian/ } \\
\text { Barremian }\end{array}$ & o & - \\
\hline 12 & $188.5-198.0$ & 14 & - & + & $\begin{array}{l}\text { (Aptian/ } \\
\text { Barremian) }\end{array}$ & $\bullet$ & $\begin{array}{l}\text { Early Aptian/ } \\
\text { Barremian }\end{array}$ & o & - \\
\hline 13 & $207.5-217.0$ & 1 & - & - & - & + & $\begin{array}{l}\text { Early Aptian/ } \\
\text { Barremian }\end{array}$ & o & - \\
\hline 14 & $217.0-226.0$ & 1 & - & - & - & - & - & 0 & $\begin{array}{l}\text { Barremian to } \\
\text { Hauterivian/ } \\
\text { Valanginan }\end{array}$ \\
\hline 15 & $226.0-235.0$ & $<1$ & - & - & - & - & - & - & - \\
\hline 16 & $235.0-244.0$ & 1 & - & - & - & - & - & * & - \\
\hline 17 & $244.0-253.0$ & 1 & - & - & - & $\bullet$ & $\begin{array}{l}\text { Hauterivian/ } \\
\text { Valanginian } \\
\end{array}$ & $*$ & - \\
\hline 18 & $253.0-262.5$ & 1 & - & - & - & $\bullet$ & $\begin{array}{l}\text { Hauterivian/ } \\
\text { Valanginian } \\
\end{array}$ & $*$ & - \\
\hline 19 & $262.5-271.5$ & $<1$ & - & $*$ & $\begin{array}{l}\text { (Aptian/) } \\
\text { Barremian }\end{array}$ & $\bullet$ & $\begin{array}{l}\text { Hauterivian/ } \\
\text { Valanginian }\end{array}$ & $*$ & - \\
\hline 20 & $271.5-281.0$ & 25 & - & * & $\begin{array}{l}\text { (Aptian/) } \\
\text { Barremian } \\
\end{array}$ & - & $\begin{array}{l}\text { Hauterivian/ } \\
\text { Valanginian }\end{array}$ & + & - \\
\hline 21 & $281.0-290.5$ & 14 & - & + & $\begin{array}{l}\text { (Aptian/) } \\
\text { Barremian }\end{array}$ & $\bullet$ & $\begin{array}{l}\text { Hauterivian } \\
\text { Valanginian }\end{array}$ & $*$ & - \\
\hline 22 & $290.5-300.0$ & 9 & - & * & $\begin{array}{l}\text { Barremian/ } \\
\text { Hauterivian }\end{array}$ & • & $\begin{array}{l}\text { Hauterivian/ } \\
\text { Valanginian }\end{array}$ & + & - \\
\hline 23 & $300.0-309.0$ & 1 & - & - & - & $\bullet$ & $\begin{array}{l}\text { Hauterivian/ } \\
\text { Valanginian } \\
\end{array}$ & - & - \\
\hline 24 & $309.0-318.5$ & 5 & - & $*$ & $\begin{array}{l}\text { Barremian/ } \\
\text { Hauterivian }\end{array}$ & $\bullet$ & $\begin{array}{l}\text { Hauterivian/ } \\
\text { Valanginian }\end{array}$ & + & - \\
\hline 25 & $318.5-327.5$ & 1 & - & * & $\begin{array}{l}\text { Barremian/ } \\
\text { Hauterivian }\end{array}$ & $\bullet$ & $\begin{array}{l}\text { Hauterivian/ } \\
\text { Valanginian }\end{array}$ & + & - \\
\hline 26 & $327.5-337.0$ & 2 & - & + & $\begin{array}{l}\text { Barremian/ } \\
\text { Hauterivian } \\
\end{array}$ & $\bullet$ & $\begin{array}{l}\text { Hauterivian/ } \\
\text { Valanginian }\end{array}$ & - & - \\
\hline 27 & $337.0-346.5$ & 0 & - & - & - & - & - & - & - \\
\hline 28 & $346.5-355.5$ & 2 & - & - & - & o & $\begin{array}{l}\text { Hauterivian/ } \\
\text { Valanginian }\end{array}$ & - & - \\
\hline 29 & $355.5-365.0$ & 1 & - & + & Early Cretaceous & $\bullet$ & $\begin{array}{l}\text { Hauterivian/ } \\
\text { Valanginian }\end{array}$ & - & - \\
\hline 30 & $365.0-374.5$ & 2 & - & - & - & $\bullet$ & $\begin{array}{l}\text { Hauterivian/ } \\
\text { Valanginian }\end{array}$ & + & - \\
\hline 31 & $374.5-376.5$ & 0 & - & - & - & - & - & - & - \\
\hline 32 & $376.5-384.0$ & 1 & - & - & - & $\bullet$ & $\begin{array}{l}\text { Valanginian/ } \\
\text { Berriasian }\end{array}$ & + & - \\
\hline
\end{tabular}


TABLE 6 - Continued

\begin{tabular}{|c|c|c|c|c|c|c|c|c|c|}
\hline \multirow[b]{2}{*}{ ن } & \multirow[b]{2}{*}{ Depth (m) } & \multirow{2}{*}{ 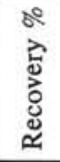 } & \multicolumn{3}{|c|}{ Foraminifera } & \multirow{2}{*}{\multicolumn{2}{|c|}{$\begin{array}{c}\text { Calcareous } \\
\text { Nannoplankton }\end{array}$}} & \multirow{2}{*}{\multicolumn{2}{|c|}{ Radiolaria }} \\
\hline & & & 音 & 苛 & & & & & \\
\hline 33 & $384.0-393.0$ & $<1$ & - & - & - & - & - & + & - \\
\hline 34 & $393.0-402.0$ & $<1$ & - & - & - & - & $\begin{array}{l}\text { Valanginian/ } \\
\text { Berriasian }\end{array}$ & + & - \\
\hline 35 & $402.0-411.5$ & 2 & - & - & - & o & $\begin{array}{l}\text { Valanginian/ } \\
\text { Berriasian }\end{array}$ & + & - \\
\hline 36 & $411.5-421.0$ & 2 & - & - & - & $\bullet$ & $\begin{array}{l}\text { Valanginian/ } \\
\text { Berriasian }\end{array}$ & + & - \\
\hline 37 & $421.0-430.5$ & 2 & - & + & Early Cretaceous & $\bullet$ & $\begin{array}{l}\text { Valanginian/ } \\
\text { Berriasian }\end{array}$ & + & - \\
\hline 38 & $430.5-440.0$ & 2 & - & * & Early Cretaceous & + & $\begin{array}{l}\text { Valanginian/ } \\
\text { Berriasian }\end{array}$ & - & - \\
\hline 39 & $440.0-449.5$ & 1 & - & - & - & - & - & + & - \\
\hline 40 & $449.5-459.0$ & 7 & - & + & Early Cretaceous & - & $\begin{array}{l}\text { Valanginian/ } \\
\text { Berriasian }\end{array}$ & o & - \\
\hline 41 & $459.0-467.5$ & 15 & - & + & Early Cretaceous & $\bullet$ & Berriasian & o & - \\
\hline 42 & $467.5-475.0$ & 8 & - & + & Early Cretaceous & $\bullet$ & Early Berriasian & o & - \\
\hline
\end{tabular}

Note: - abundant; o common; * frequent; + rare; - absent.

the same species occur in Core 27. A Barremian to Hauterivian age is attributed to this "interval with Dorothia hauteriviana." No washed residue was obtained from Core 23.

The occurrence of foraminifera below Core 26 is very patchy. The rare microfaunas are always very poor and badly preserved (Cores $29,37,38$, and 40 to 42 ). Radiolaria dominate most of the washed residues. The few foraminifera (almost exclusively lagenids) allow no age determination.

\section{Coccoliths}

Coccolith assemblages ranging in age from earliest Cretaceous to Quaternary (Gephyrocapsa oceanica Zone) occur in the 475-meter section (Cores 1 to 42 ) at Site 306.

Most of the cored section is Early Cretaceous in age and apparently represents continuous deposition. Chert layers are numerous and sediment recovery was negligible.

Core $1(1-10 \mathrm{~m})$ contains a relatively uncontaminated foraminifer-coccolith ooze of Quaternary age at the top, but the rest of the core is a mixture of species representative of most Late Cretaceous and Cenozoic zones. Fragments of chalk in the lower part of the core contain poorly preserved Albian to Turonian coccoliths.

The Lithraphidites alatus Zone, in Cores 2 to 3 (10-28 $\mathrm{m})$, and the Eiffellithus turriseiffeli Zone, in Cores 4 to 5 $(38-66 \mathrm{~m})$, are both associated with Albian foraminifer assemblages (Cores 2 to 4 ).

Cores 6 to $8(76-123 \mathrm{~m})$ contain poorly preserved assemblages of the Aptian to Albian Parhabdolithus angustus Zone. The latest appearance of Watznaueria oblonga, here, duplicates its occurrence at Site 305 and indicates a correlation for Cores 306-6 and 305-57. Cores 6 to 8 at Site 306 correspond to Cores 55 to 57 at Site 305 .

\section{Radiolaria}

This site was drilled to continue the sequence of continuous coring at Site 305 . All the cores recovered are Mesozoic, except the first which is a mixture of sediments of Neogene and Cretaceous age.

Radiolaria are few and poorly preserved in Cores 2 to 4 , common, moderately to poorly preserved in Cores 5 to 14 and few and poorly preserved in Cores 16 to 19 . Radiolarian abundance and preservation are very rare and very poor from Cores 20 through 39 , with the exception of Core 21 where they are few and moderate. In Core 40 they are common and moderate; Core 41 , abundant and moderate; and Core 42, few and moderate.

Samples of the hard flint-like chert were prepared from the core catchers of Cores 28, 30, and 32 through 35 . As at Site 305 , they contained only very rare, very poor, unidentifiable Radiolaria. Generally only recrystallized fragments were recovered.

Cores 2 to $4(9.5-47 \mathrm{~m})$ belong to the Dictyomitra somphedia Zone. Cores 5 through 12 at a depth of 47 to 160.5 meters Acaeniotyle umbilicata Zone contain a fauna which with further study may prove to be related to some of the forms described by Aliev (1965) from the late Early Cretaceous of Azerbaidzhan. Cores 14 to 19 (217-271 m) belong to the Eucyrtis tenuis Zone, and Core $21(281-290 \mathrm{~m})$ to the Sethocapsa trachyostraca Zone. The Radiolaria in Cores 20 and 22 to 39 are either missing or are too poor to give an age assignment. Cores 40 to 42 are below the oldest core (Site 196, Core 4) of Leg 20, which could be dated on the basis of nannofossils. It was considered to be Valanginian-early Hauterivian in age. The fauna in Cores 40 and 42 is very similar to the next-older core recovered (Core 196-5). It had no co-occurring calcareous fossils and on the basis of the Radiolaria was considered to be Neocomian?Late Jurassic in age. This fauna is now considered to be Valanginian-Berriasian on the basis of the associated 


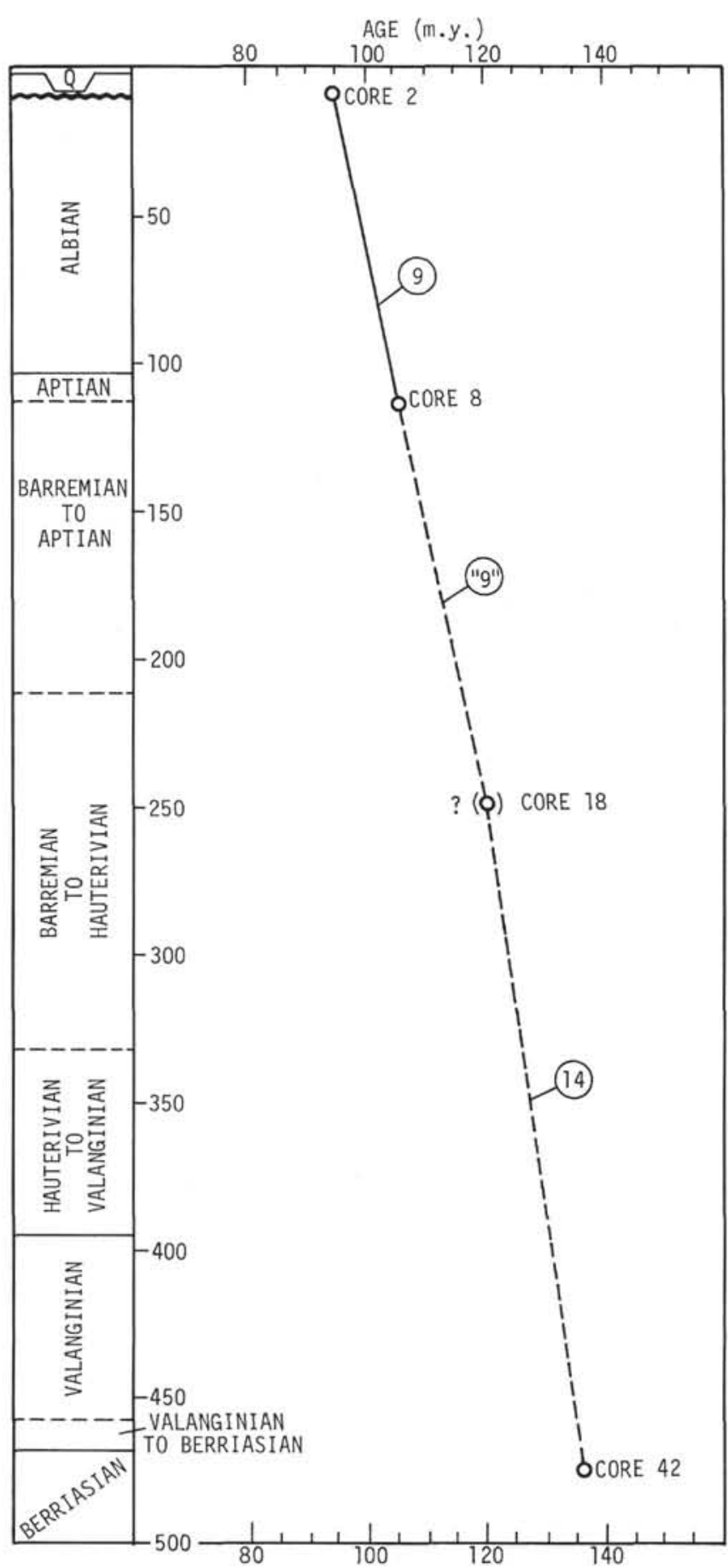

Figure 7. Accumulation rate curve calculated for Site 306. Circled numbers give accumulation rate in $\mathrm{m} / \mathrm{m} . \mathrm{y}$. for each segment.

nannofossils in Cores 40 to 42 and belongs to the Sphaerostylus lanceola Zone.

\section{SEDIMENTATION RATES}

The Berriasian to Albian section in Cores 1 to 42 (10$475 \mathrm{~m}$ ) accumulated at an average rate of $11 \mathrm{~m} / \mathrm{m} . \mathrm{y}$. As stage boundaries are only approximately located because of poor assemblages or limited recovery, sedimentation rates for smaller intervals are less reliable (Figure 7).

A comparison of the interval from the top of Albian to the top of the Hauterivian at Sites 305 and 306 shows sedimentation average rates of about $10 \mathrm{~m} / \mathrm{m} . \mathrm{y}$. (305, Cores 42 to $67 ; 306$, Cores 1 to 13). Shorter intervals show more variation. The lack of well-established data points in the Early Cretaceous results in only approximate sedimentation rates.

\section{SUMMARY AND CONCLUSIONS}

The principal result of drilling at Site 306 was the penetration of nearly a half kilometer of cherts and carbonate rocks, mainly of Early Cretaceous age. Even though the button-toothed cone bit with sealed journal bearings was able to drill in these hard rocks for a record length of time, we were not able to complete our primary objective of coring the complete sedimentary section and into basement.

It had not been expected that the lower transparent layer of the reflection profiles would turn out to be so cherty. Much of it was impure, with clay and carbonate admixtures, typical of many porcellanites, but nevertheless resisted drilling.

Like Site 305 , a sufficient amount of fossil material was recovered at Site 306 that the progress of the hole could be followed, and a correlation with Site 305 could be made. Also, like Site 305, there was not sufficient material for wide distribution of samples. In several instances nearly all the meager scrappings of chalk from crusts and vugs in the chert were used for smear slides and a search for fossils. Coccoliths were most useful for dating the rocks.

The nature and age of basement remain unknown. As estimated from the reflection record, the 475-meter total depth of the hole probably was about 80 meters above basement. The increase in volcanogenic components in the lowest few cores suggests some proximity to basement, by analogy with the base of the sedimentary section on the Ontong-Java and Magellan plateaus. Figure 8 is a summary of Site 306 results.

\section{REFERENCES}

Aliev, Kh. Sh., 1965. Radiolarians of the Lower Cretaceous deposits of northeastern Azerbaidzhan and their stratigraphic significance: Izd. Akad. Nauk. Az. SSR, Baku.

Chase, T. E., Menard, H. W., and Mammerickx, J., 1971, Topography of the North Pacific: Institute of Marine Resources, University of California, San Diego.

Heath, G. R. and Moberly, R., 1971. Cherts from the western Pacific. In Winterer, E. L., Riedel, W. R., et al., Initial Reports of the Deep Sea Drilling Project, Volume 7: Washington (U. S. Government Printing Office), p. 9911007.

Jones, J. B. and Segnit, E. R., 1971. The nature of opal. I. Nomenclature and constituent phases: J. Geol. Soc. Australia, v. 18, p. 57-68.

Lancelot, Y., 1973. Chert and silica diagenesis in sediments from the Central Pacific. In Winterer, E. L., Ewing, J. I., et al., Initial Reports of the Deep Sea Drilling Project, Volume 17: Washington (U. S. Government Printing Office), p. $377-405$. 


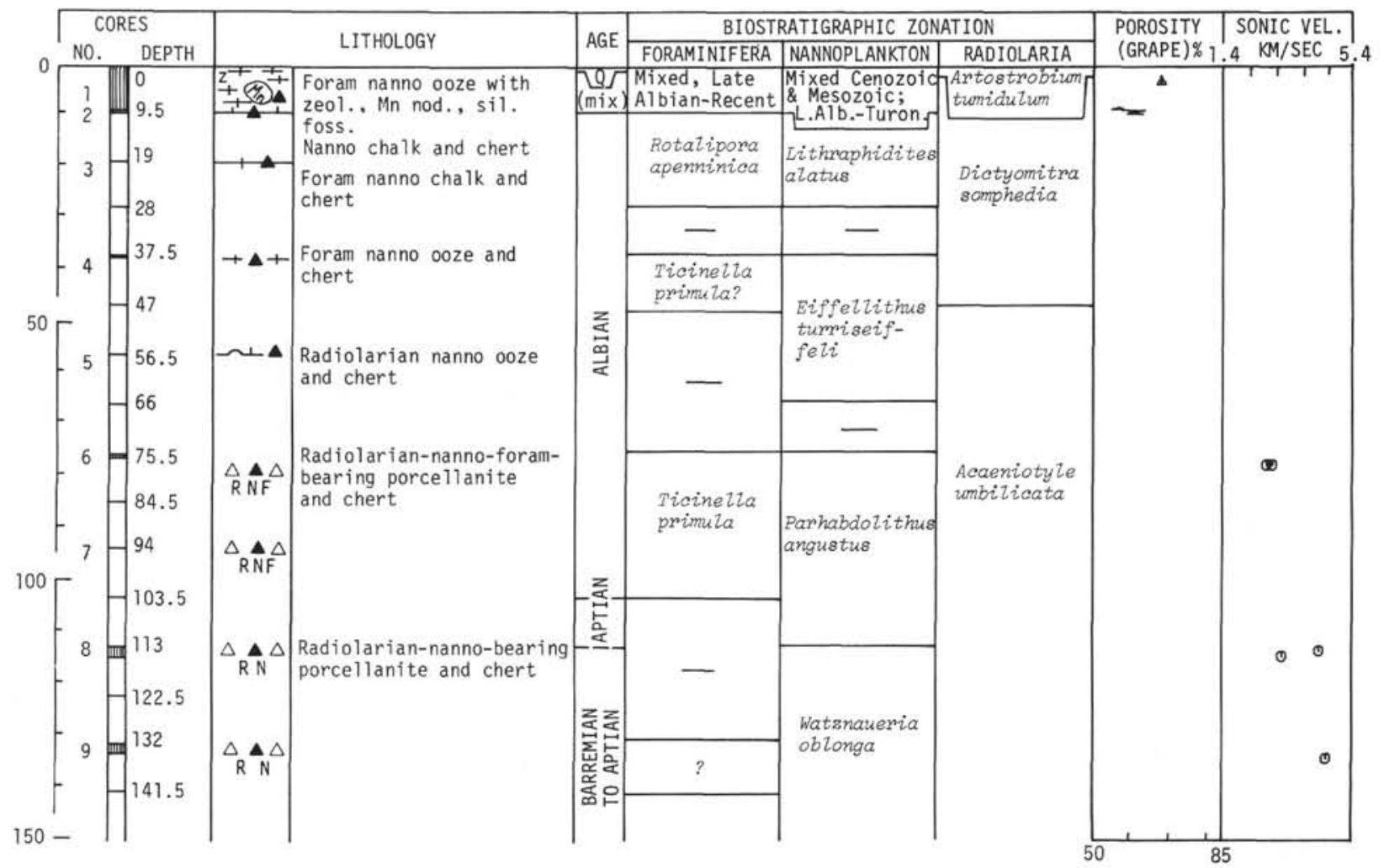

Figure 8. Summary of coring, lithology, biostratigraphy, and physical properties at Site 306.

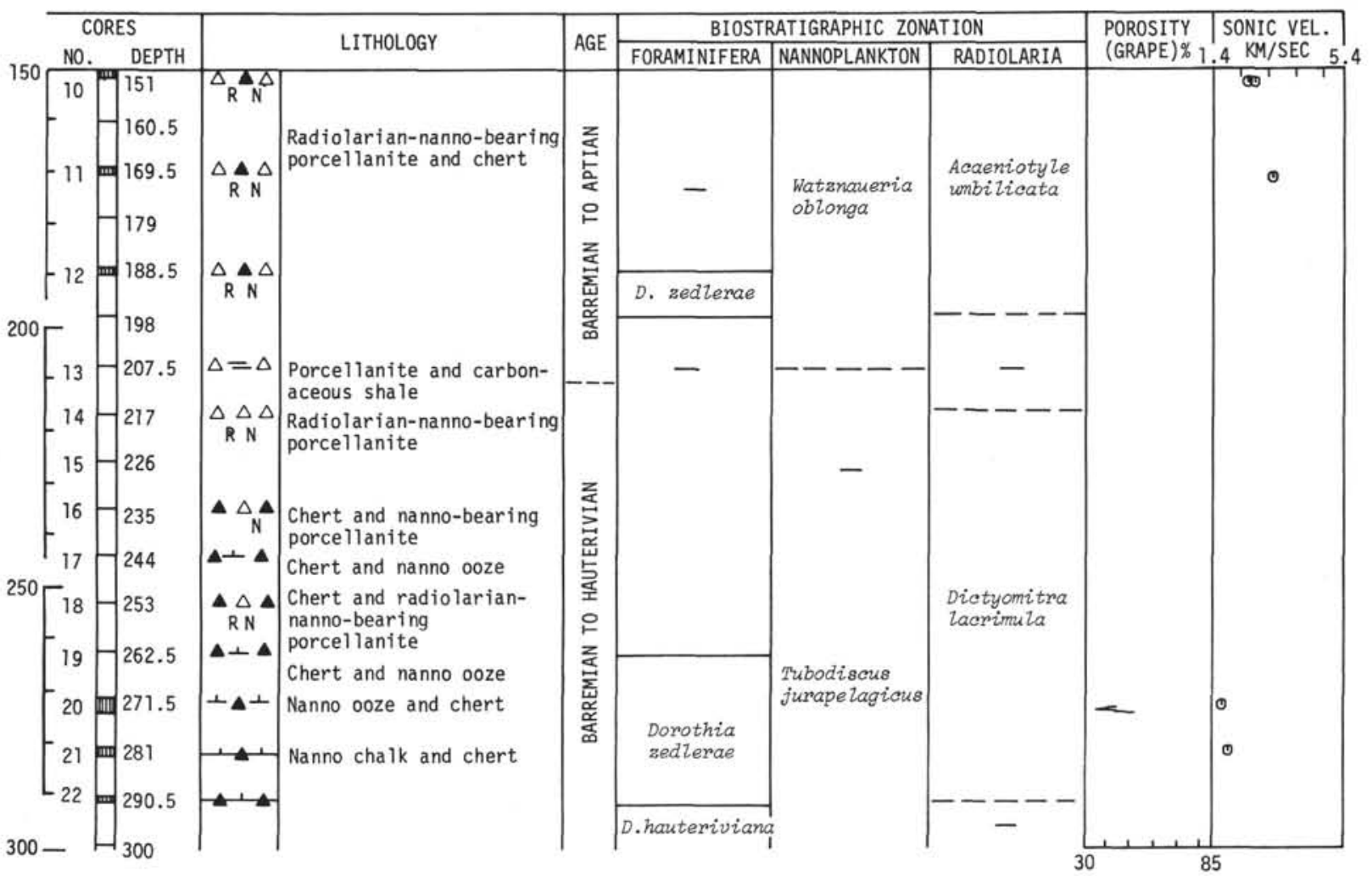

Figure 8. (Continued). 


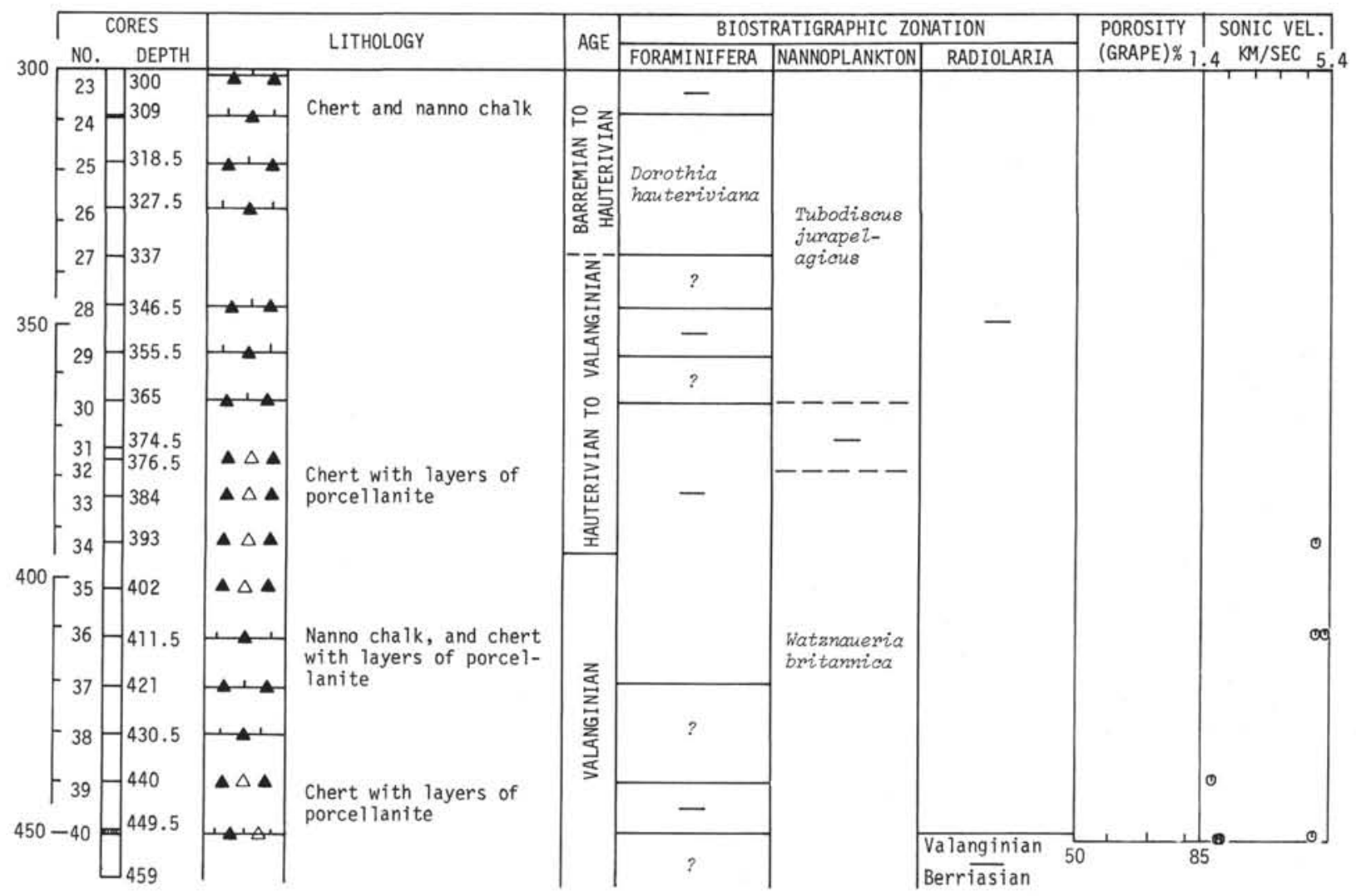

Figure 8. (Continued).

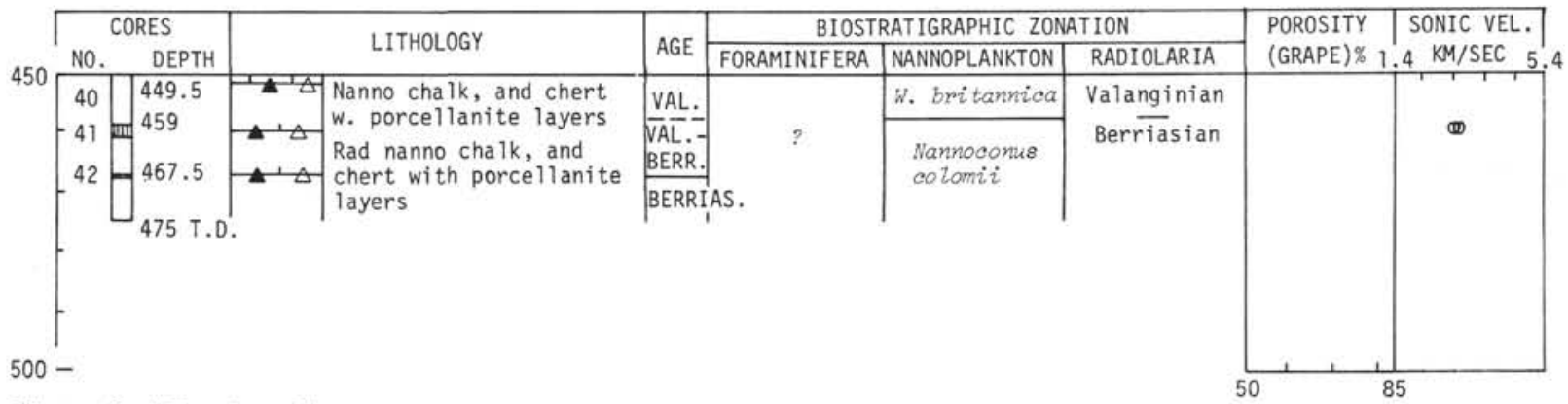

Figure 8. (Continued). 


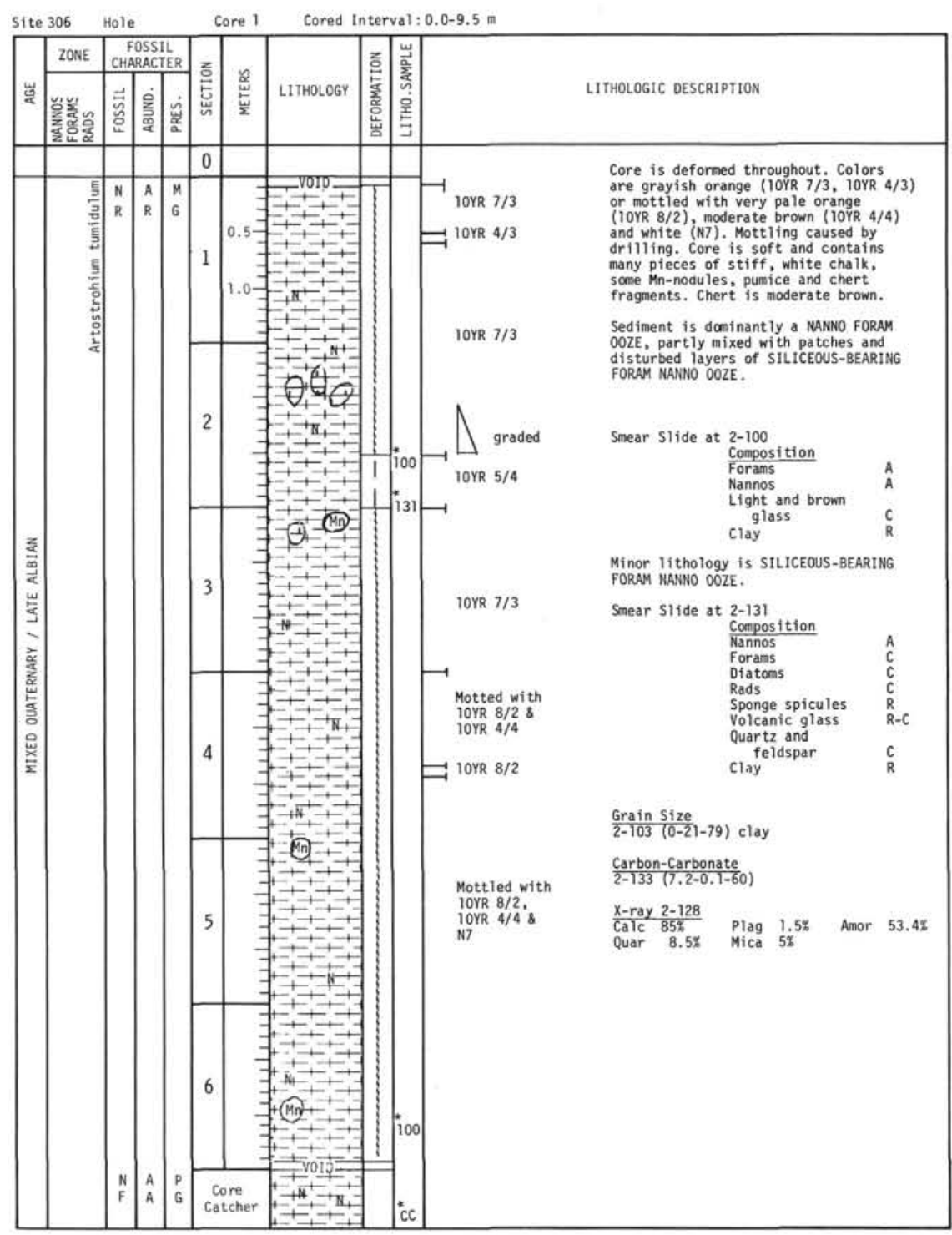

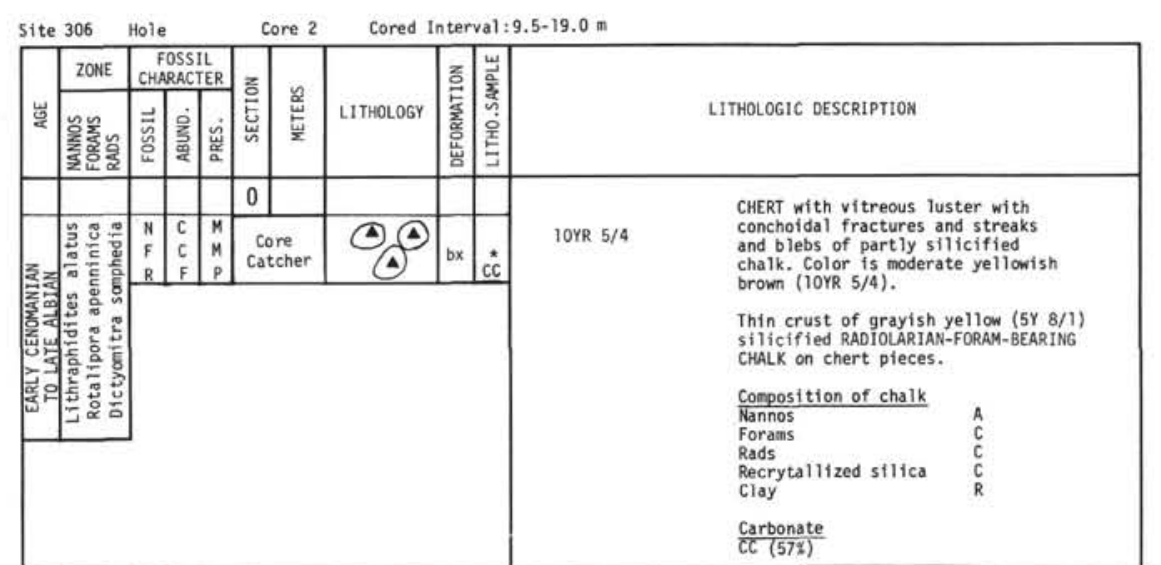

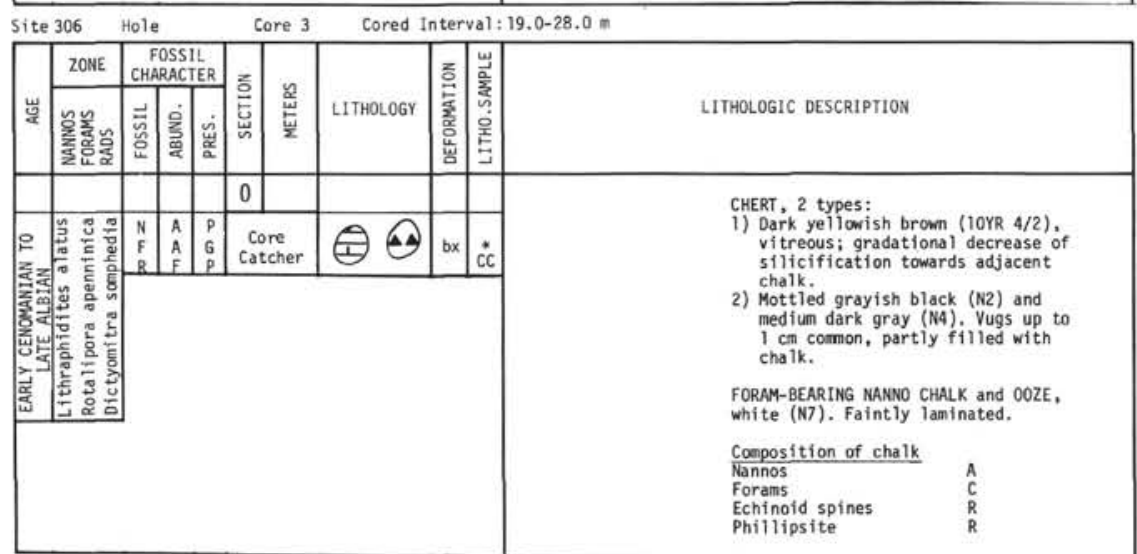

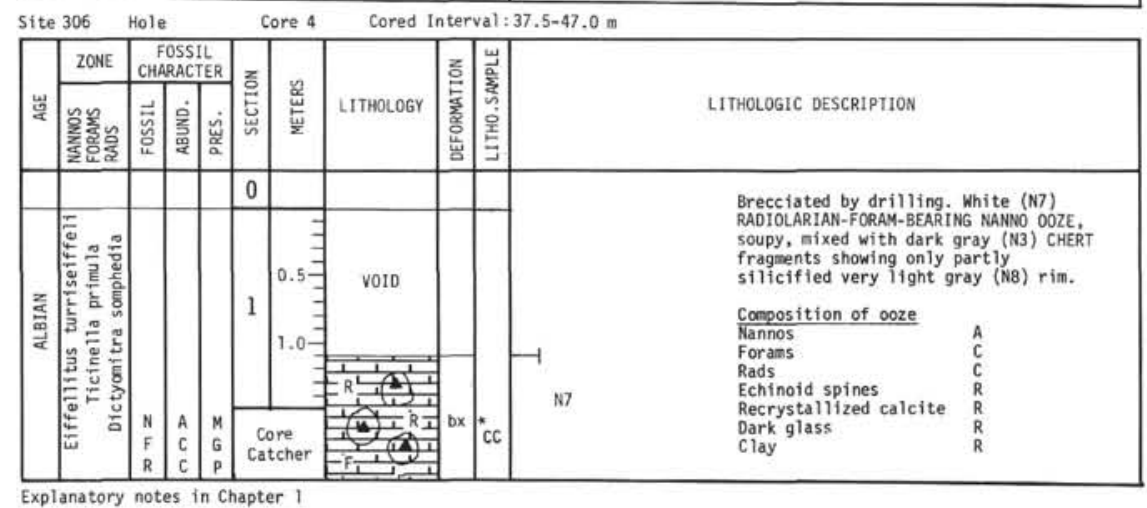




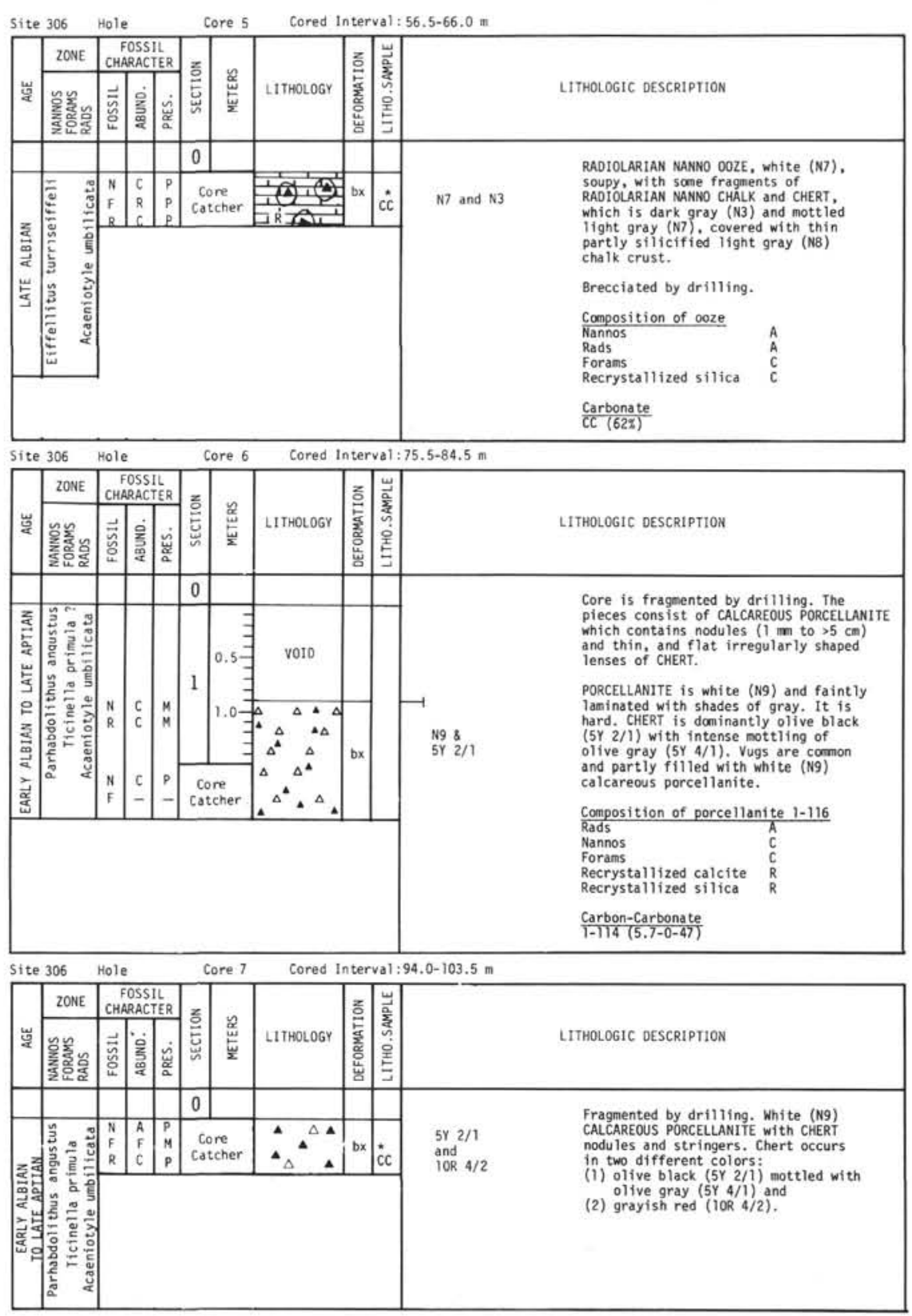

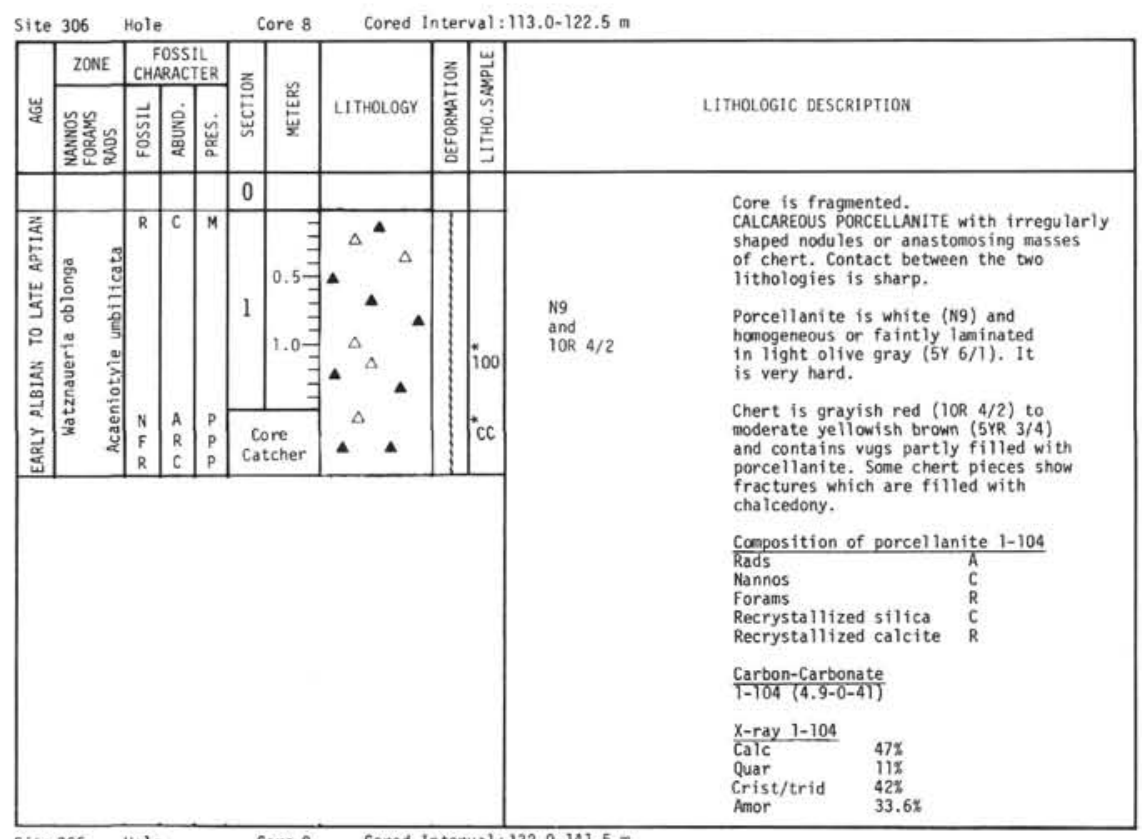

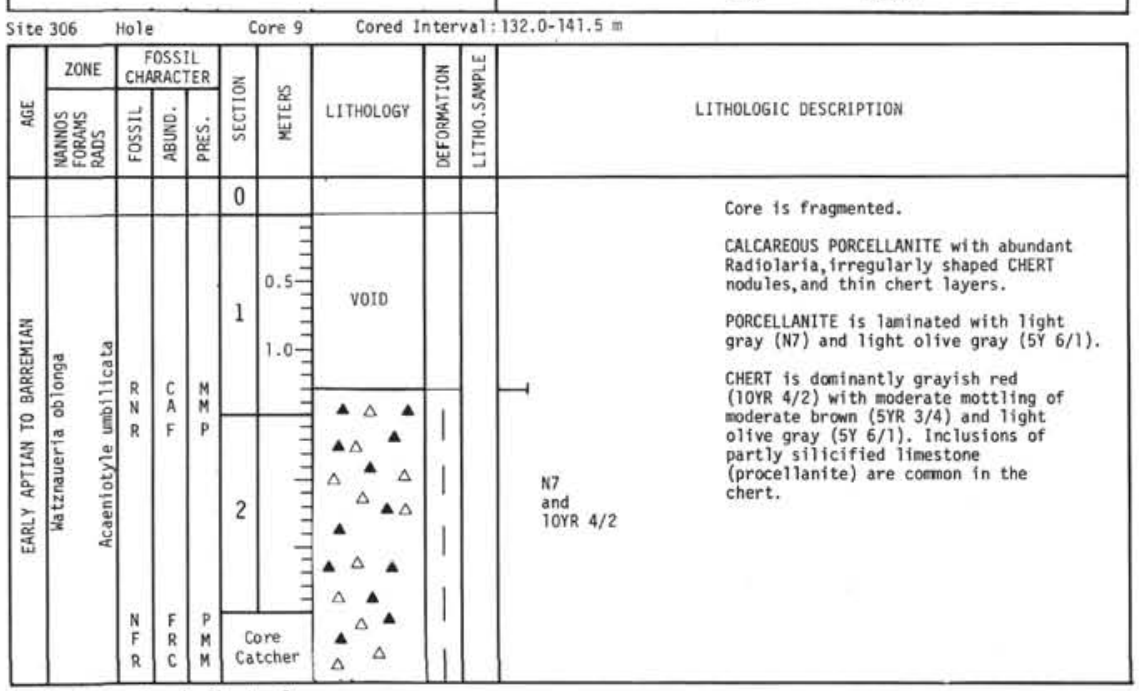

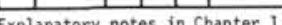




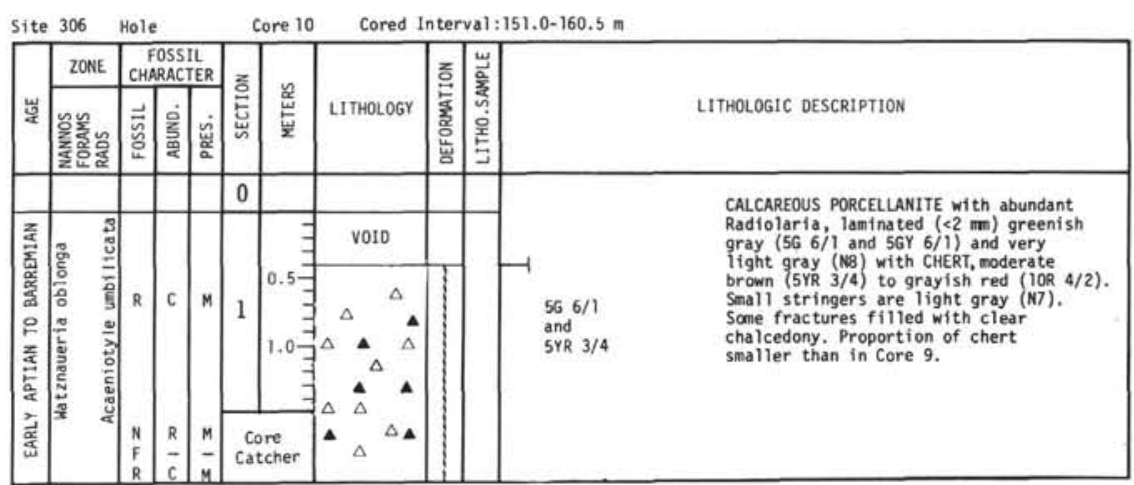

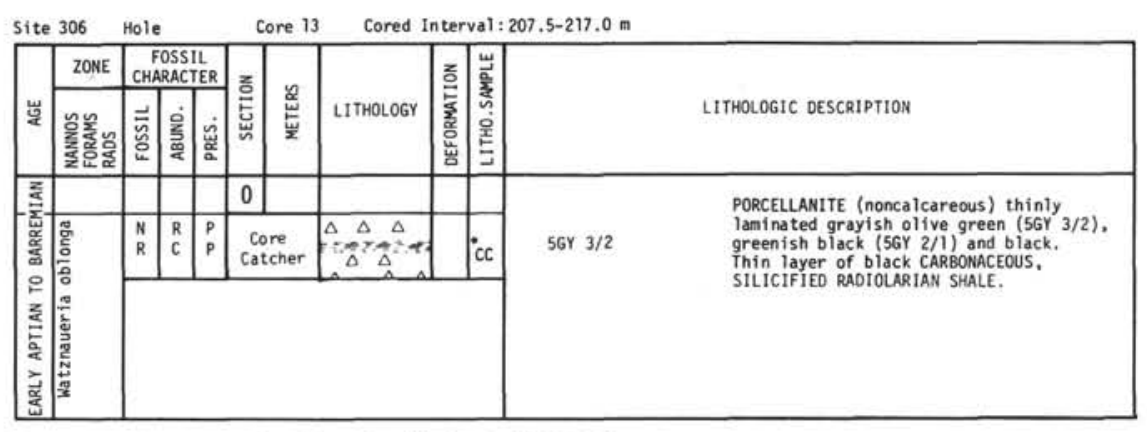

\begin{tabular}{|l|l|l|l|l|l|l|l|}
\hline Site 306 & Hole \\
\hline
\end{tabular}

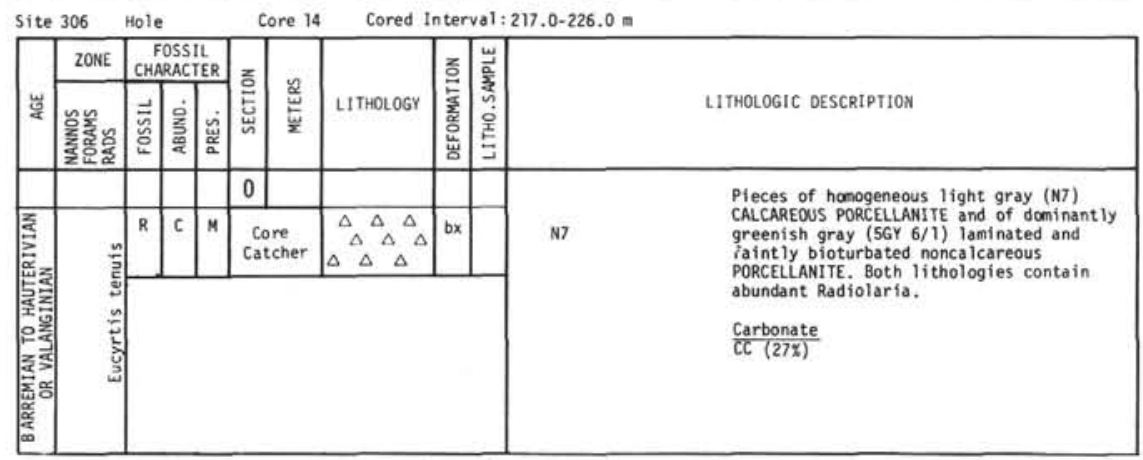

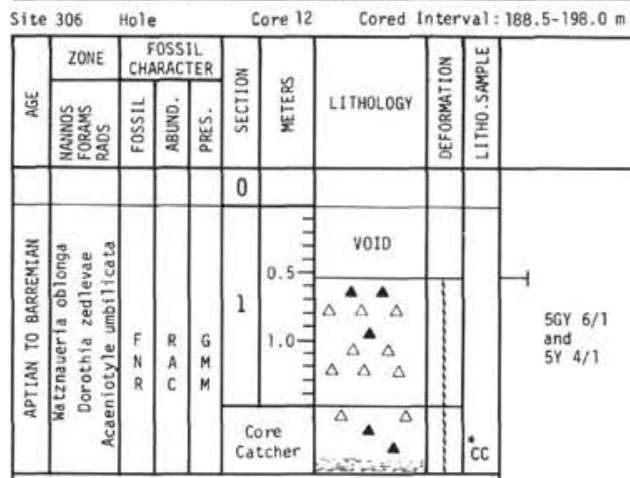

LITHOLOGIC DESCRIPTION

\section{Core is fragmented.}

CALCAREOUS PORCELLANITE with some
CHERT NodU les.

PORCELLANITE is greenish gray
(5GY $6 / 11)$ and light gray (N7)

with numerorus train bytr laminated

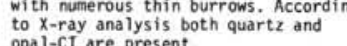

CHERT is mottled with olive gray
$(5 Y 4 / 1)$ and greenish gray $(566 / 1)$.

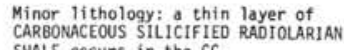
sater site at

\begin{tabular}{|c|c|c|c|c|c|c|c|c|}
\hline Site & & Hole & & Core 15 & Cored I & iterval & $: 226.0-235.0 \mathrm{~m}$ & \\
\hline & 20NE & $\begin{array}{c}\text { FOSSI } \\
\text { CHARACT }\end{array}$ & & & & z) & & \\
\hline 宸 & 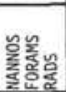 & 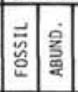 & & 总 & LITHOLOGY & 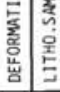 & . & LITHOCOGIC DESCRIPTION \\
\hline & & & & 0 & & & & Sall amount of scrapings retrieved, \\
\hline & & & & $\begin{array}{l}\text { Core } \\
\text { Catcher }\end{array}$ & & & & appears to be porcel lanite. \\
\hline
\end{tabular}

Smear s1ide at

$$
\begin{aligned}
& \text { Composition } \\
& \text { Rads } \\
& \text { Forams } \\
& \text { Recrystallized } \\
& \text { silica } \\
& \text { Pyrite } \\
& \text { Clay } \\
& \text { Dark glass }
\end{aligned}
$$

Carbonate (porcellanite) 

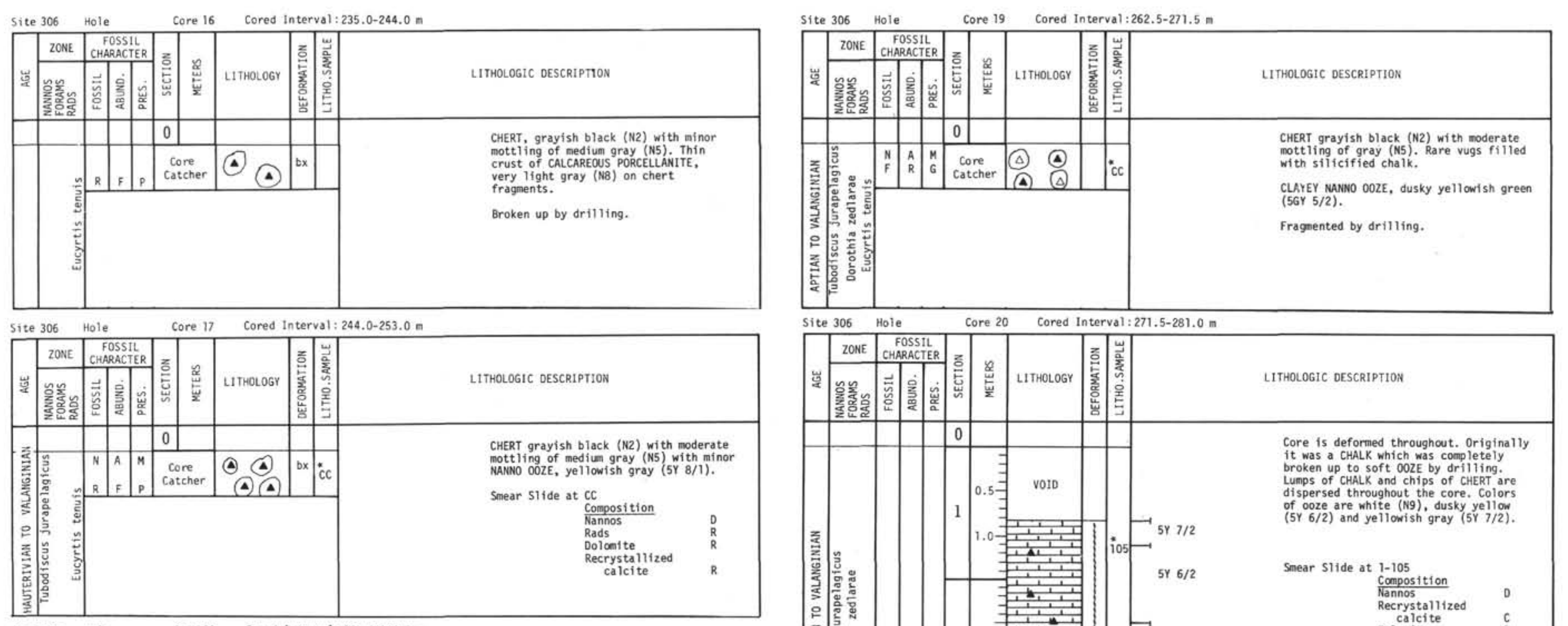

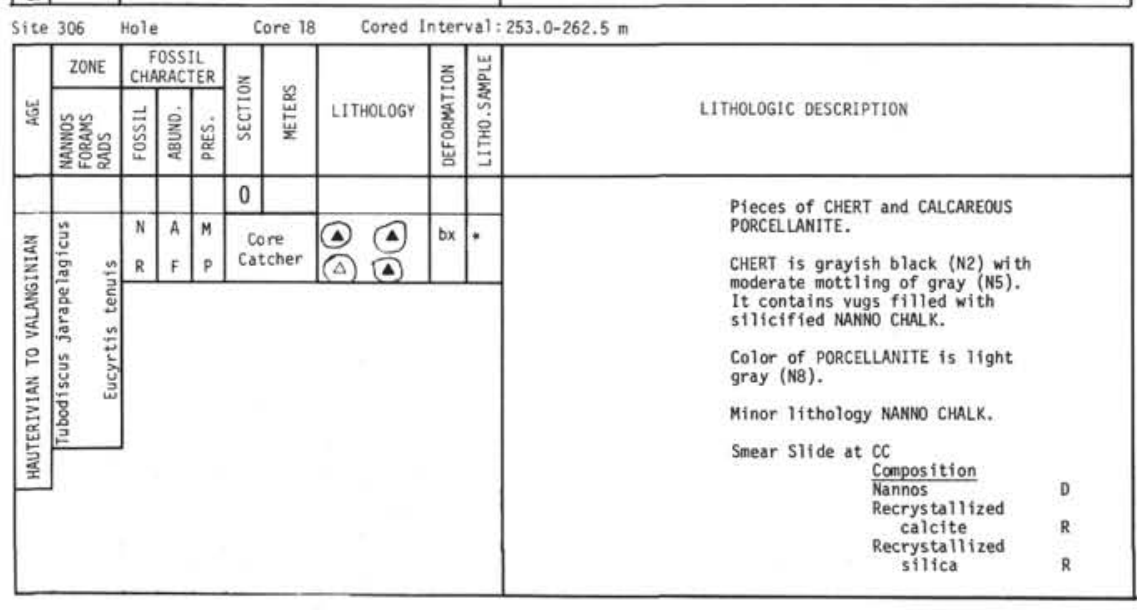

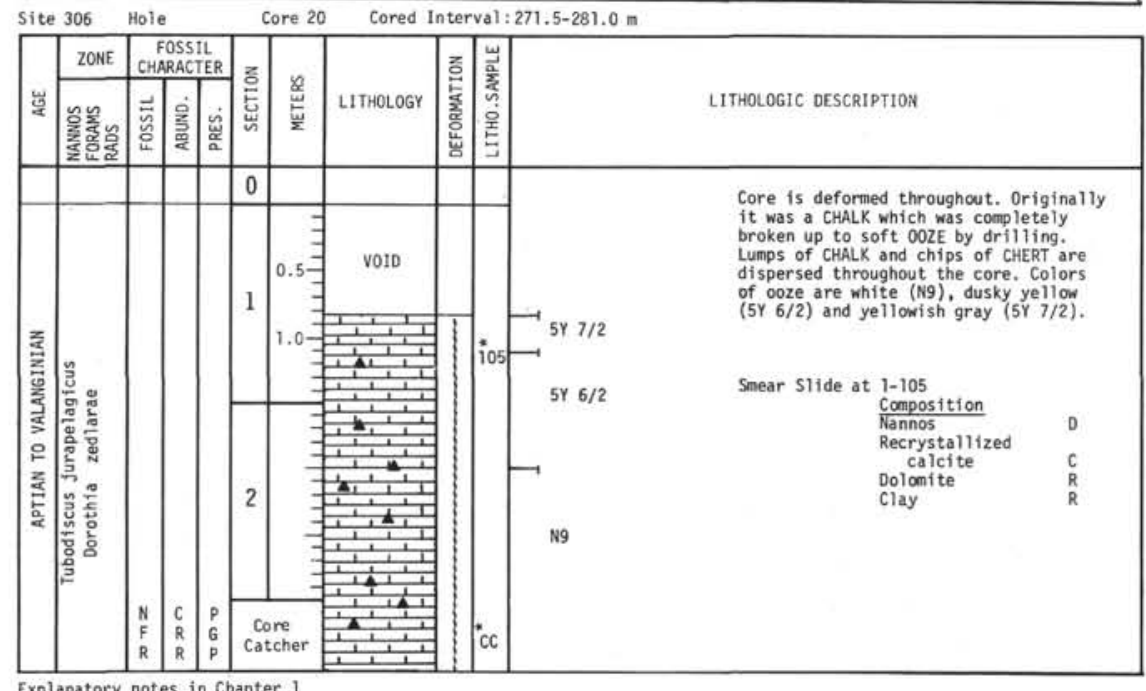




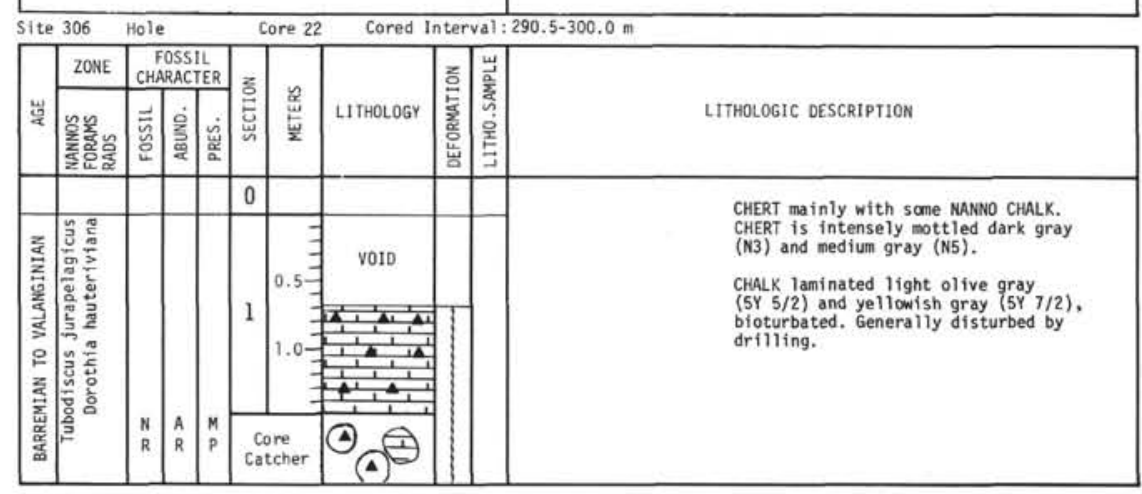

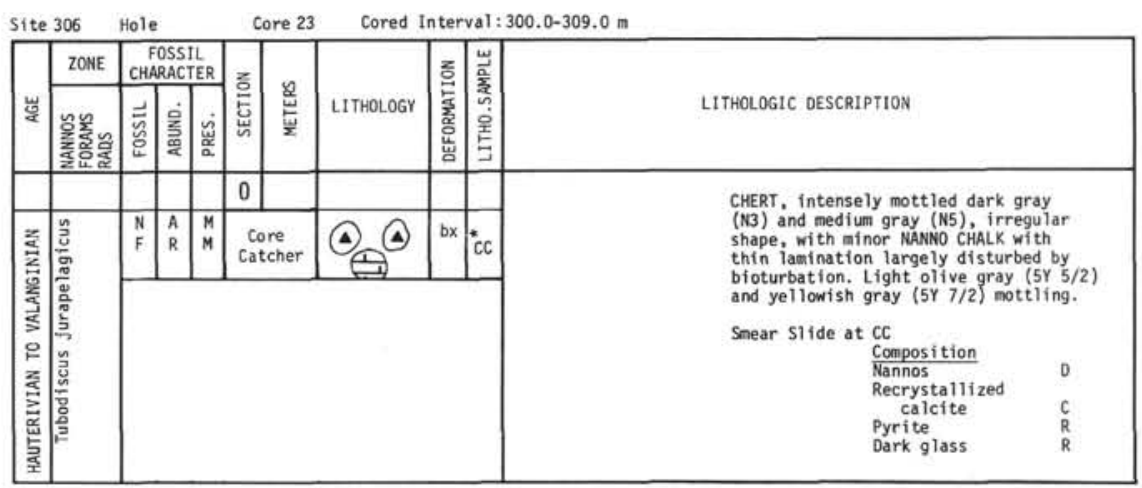

Site 306 Hole Core 24 Cored Interval: 309.0-218.5

\begin{tabular}{|c|c|c|c|c|c|c|c|c|}
\hline 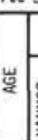 & 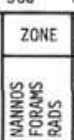 & 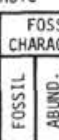 & & & $\begin{array}{l}\frac{y}{3} \\
\frac{3}{2}\end{array}$ & LITHOLOGY & 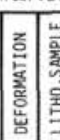 & LITHOLOGIC DESCRIPTION \\
\hline & & & & 0 & & & & Core brecciated by drilling. \\
\hline & 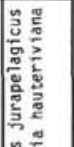 & & & 1 & & voto & & 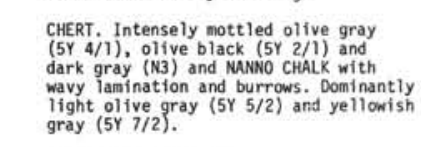 \\
\hline , & 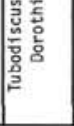 & \begin{tabular}{|l|l}
$N$ & $A$ \\
$F$ & $C$
\end{tabular} & $\begin{array}{l}\hat{c} \\
c\end{array}$ & & \begin{tabular}{|l|} 
ore \\
tcher
\end{tabular} & (4) (4) & $\mathrm{bx} ; \mathrm{cc}$ & 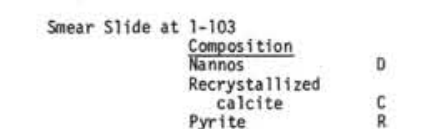 \\
\hline
\end{tabular}

$\frac{\text { Carbon-carbonate }}{1-102(11.5-0.2-2-95)}$

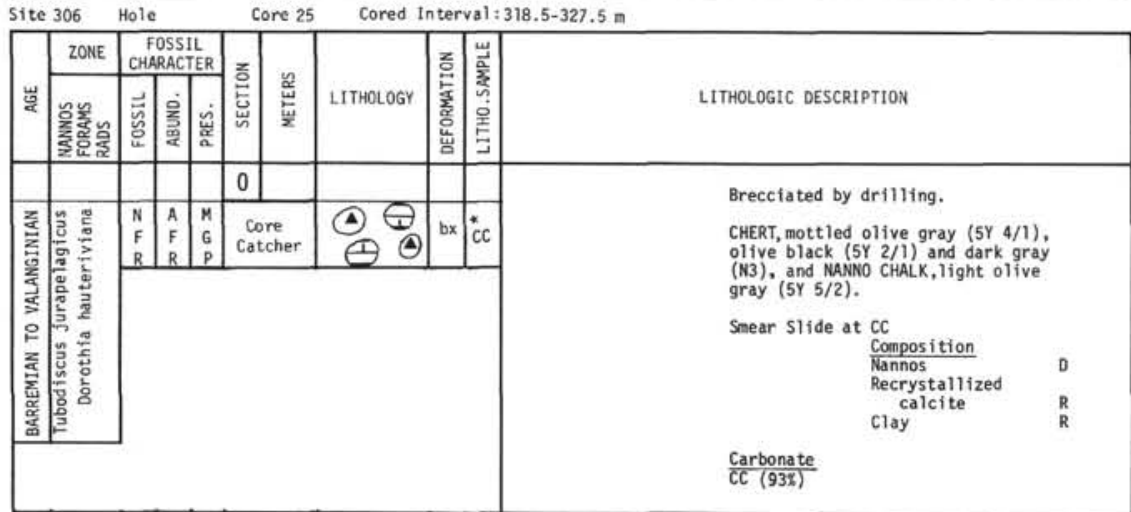

Explanatory notes in Chapter 1 


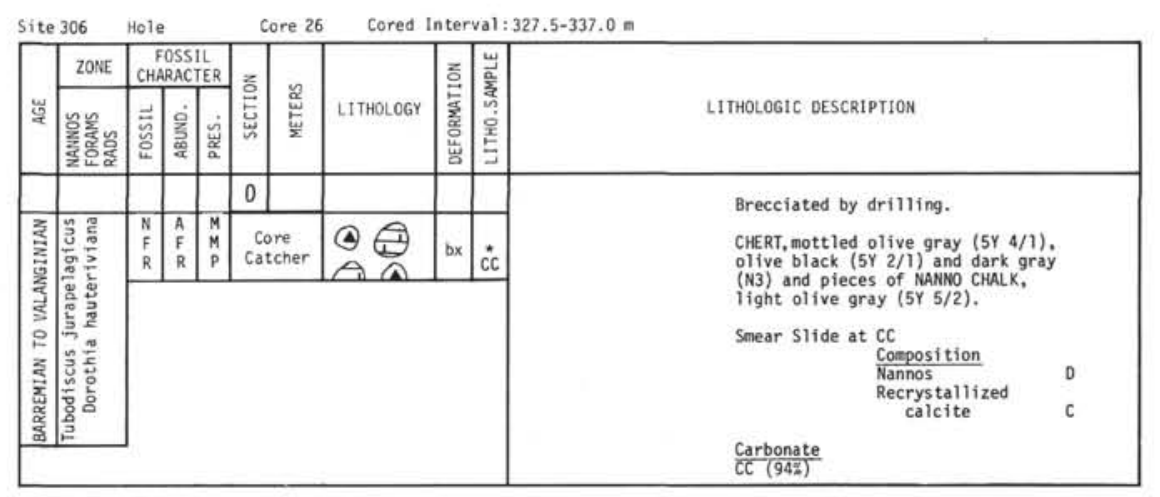

Site 306, Core 27, 337.0-346m: NO RECOVERY

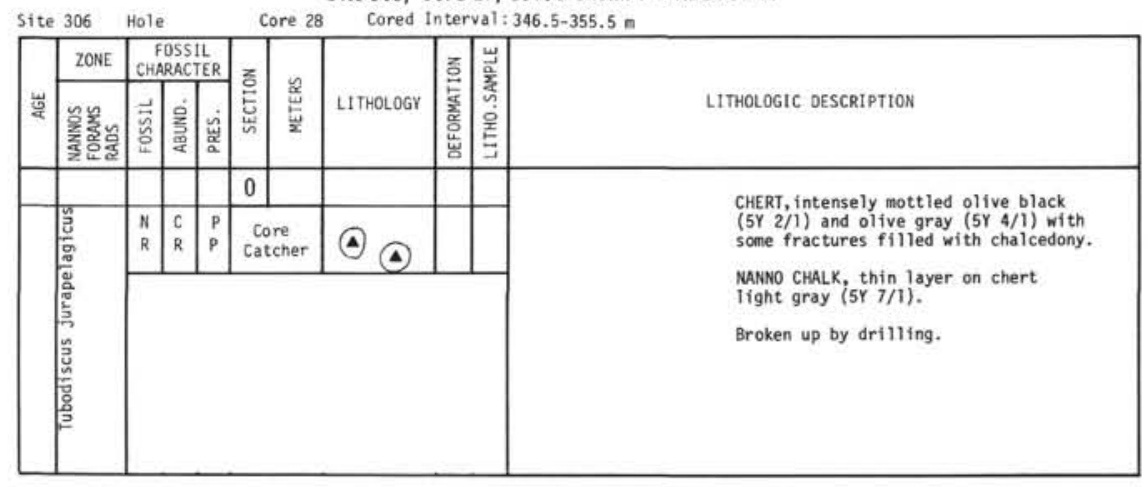
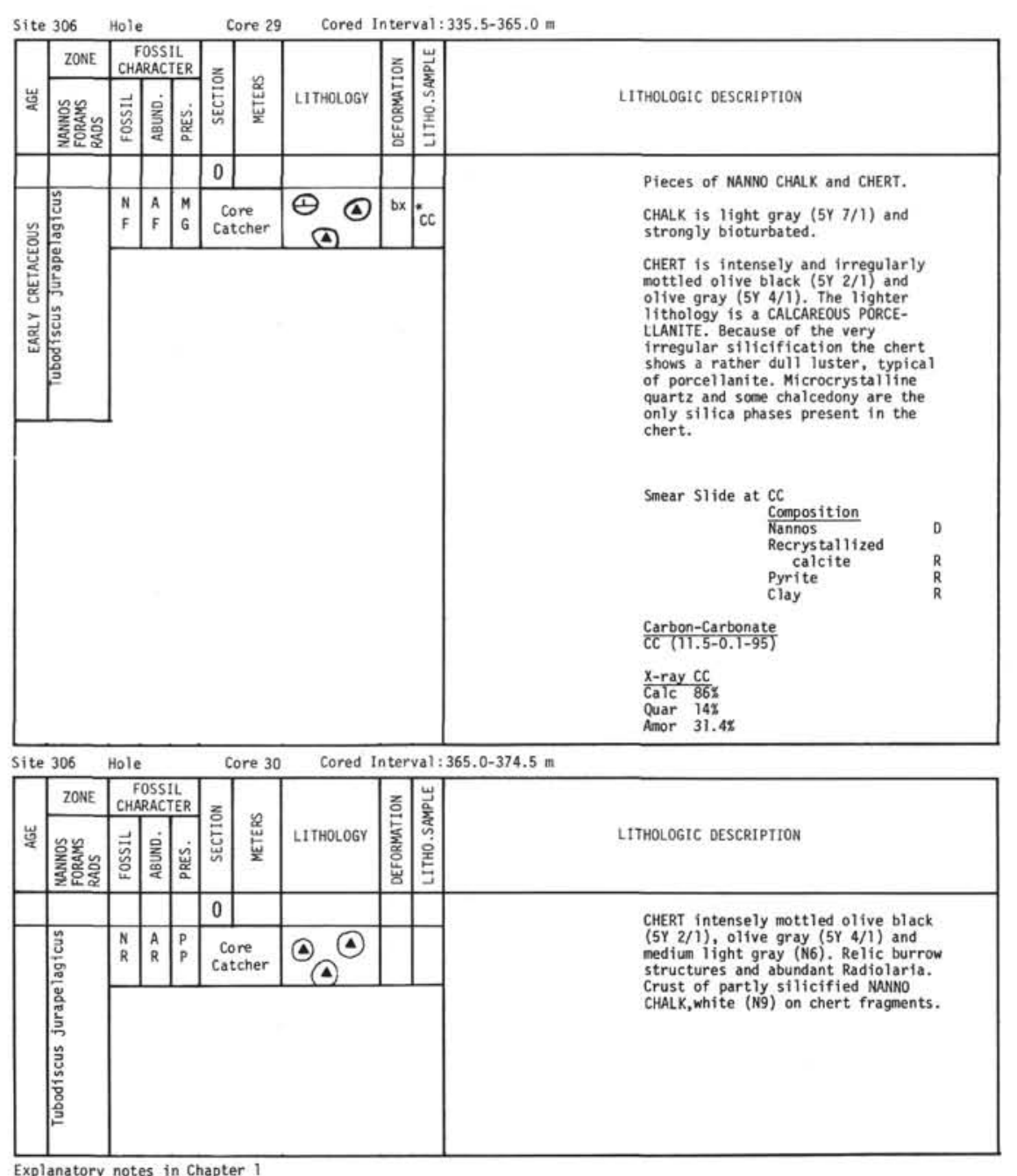

Site 306, Core 31, 374.5-376m: NO RECOVERY 

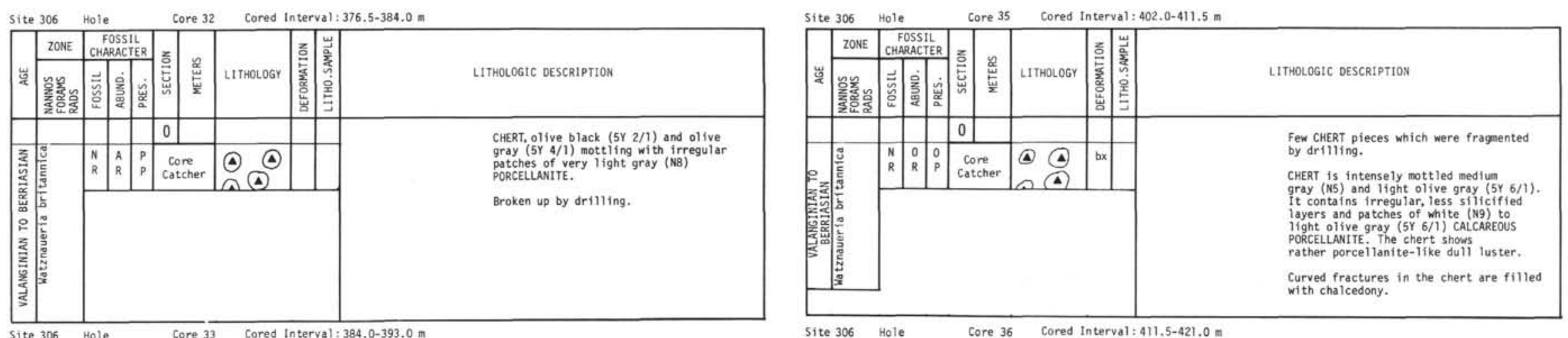

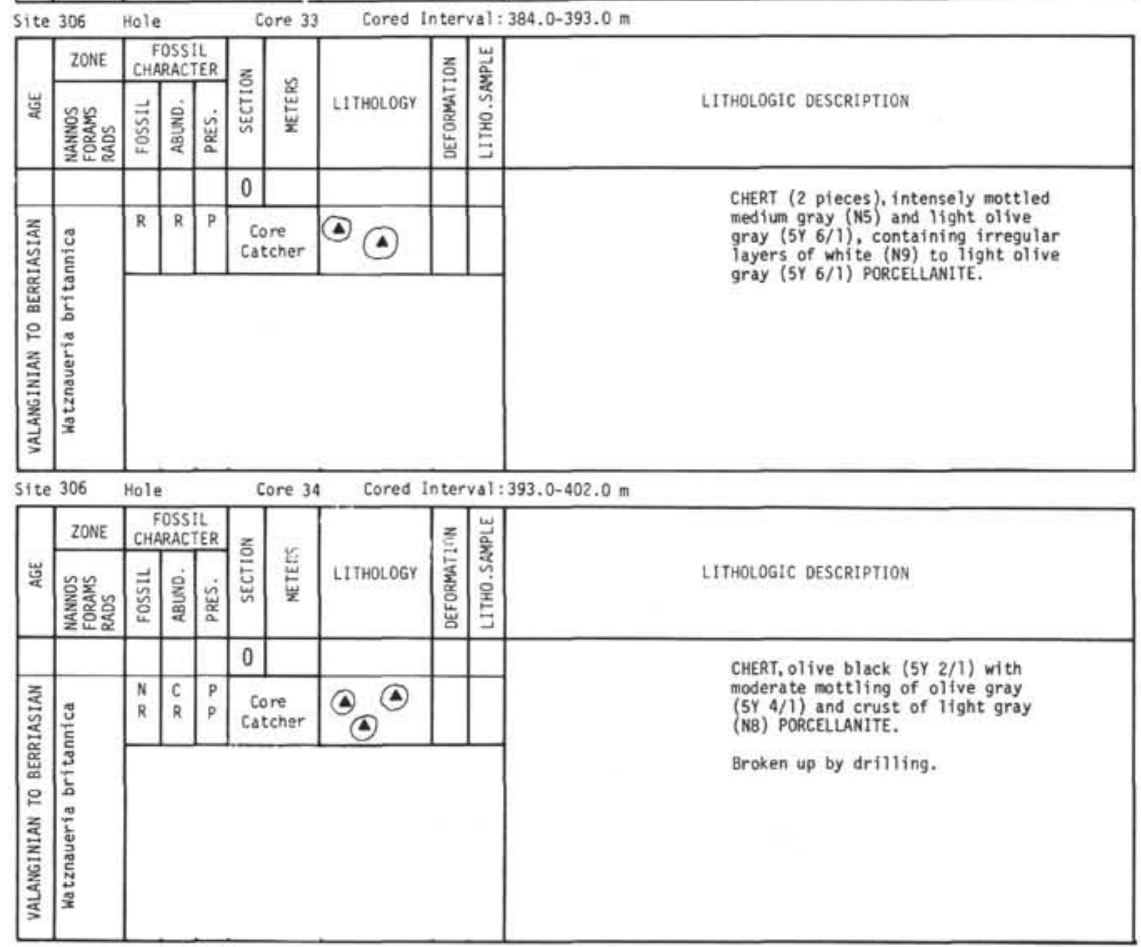

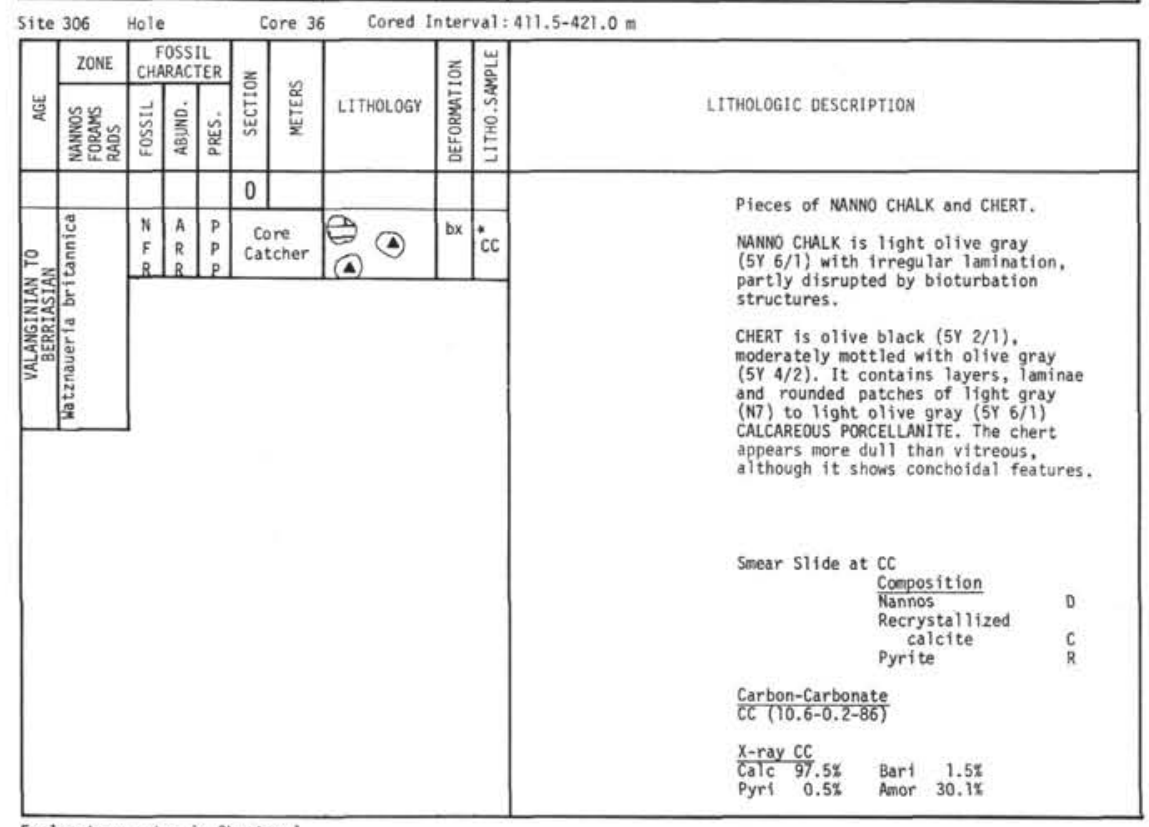




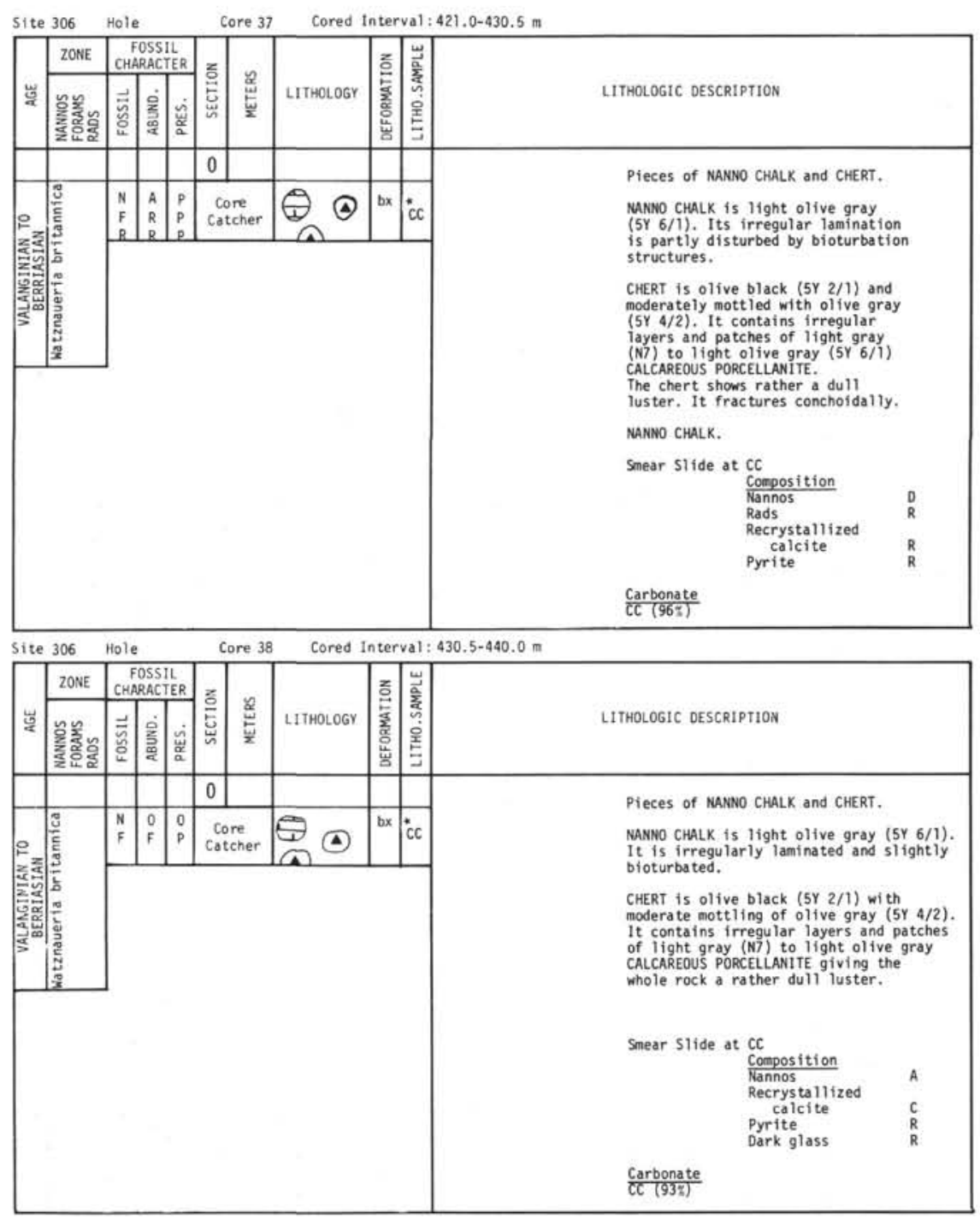

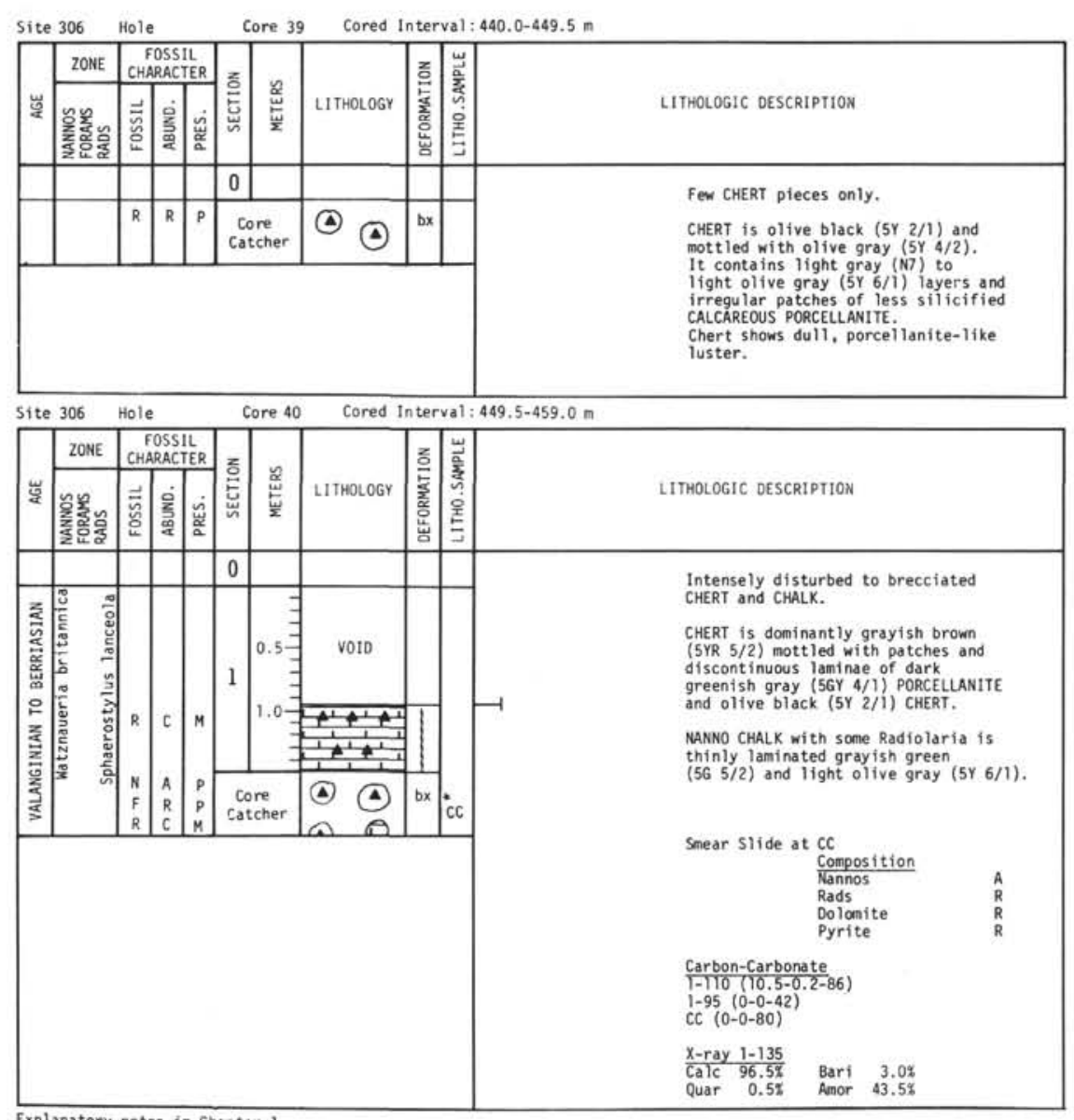

Explanatory notes in Chapter 1 


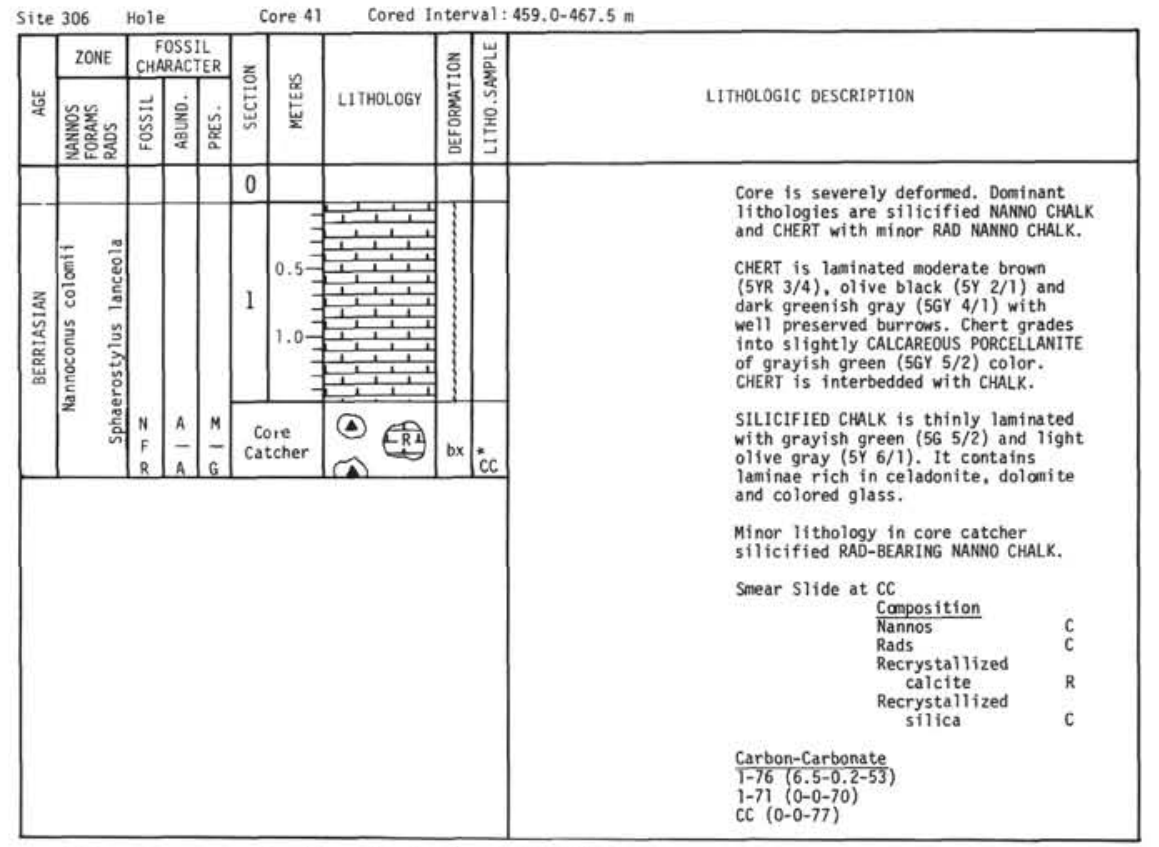

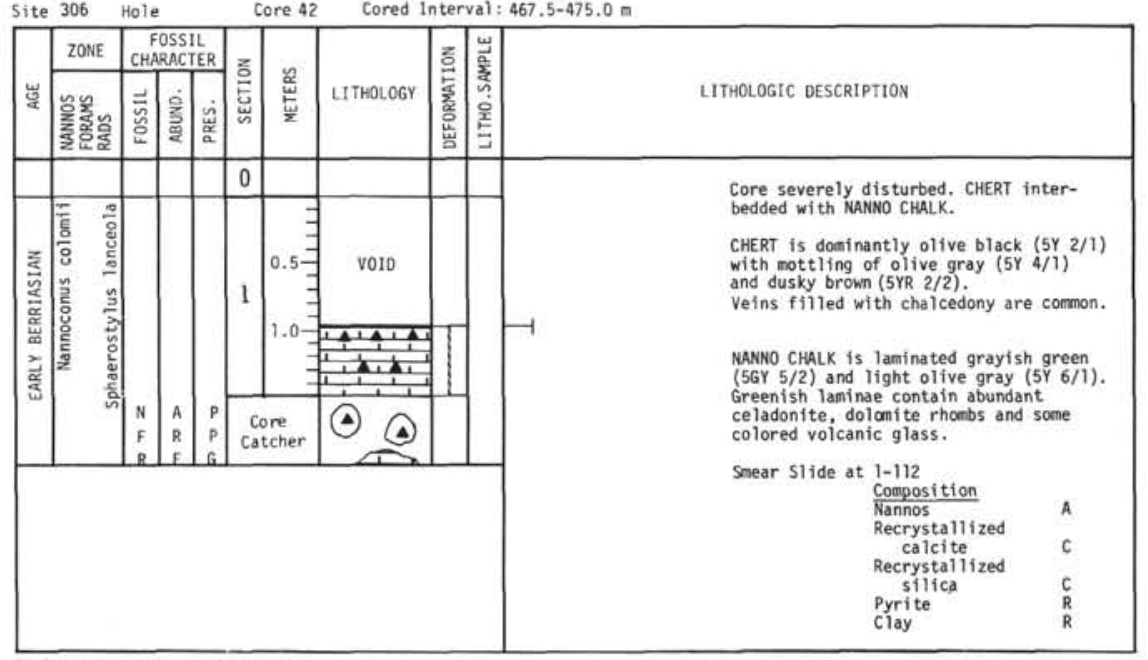

Explanatory notes in Chapter 1 
CORE 306-1

- $=$ GRAPE WET-BULK DENSITY, g/cC

๑ Syringe porosity, \%

COMPRESSIONAL SOUND VELOCITY

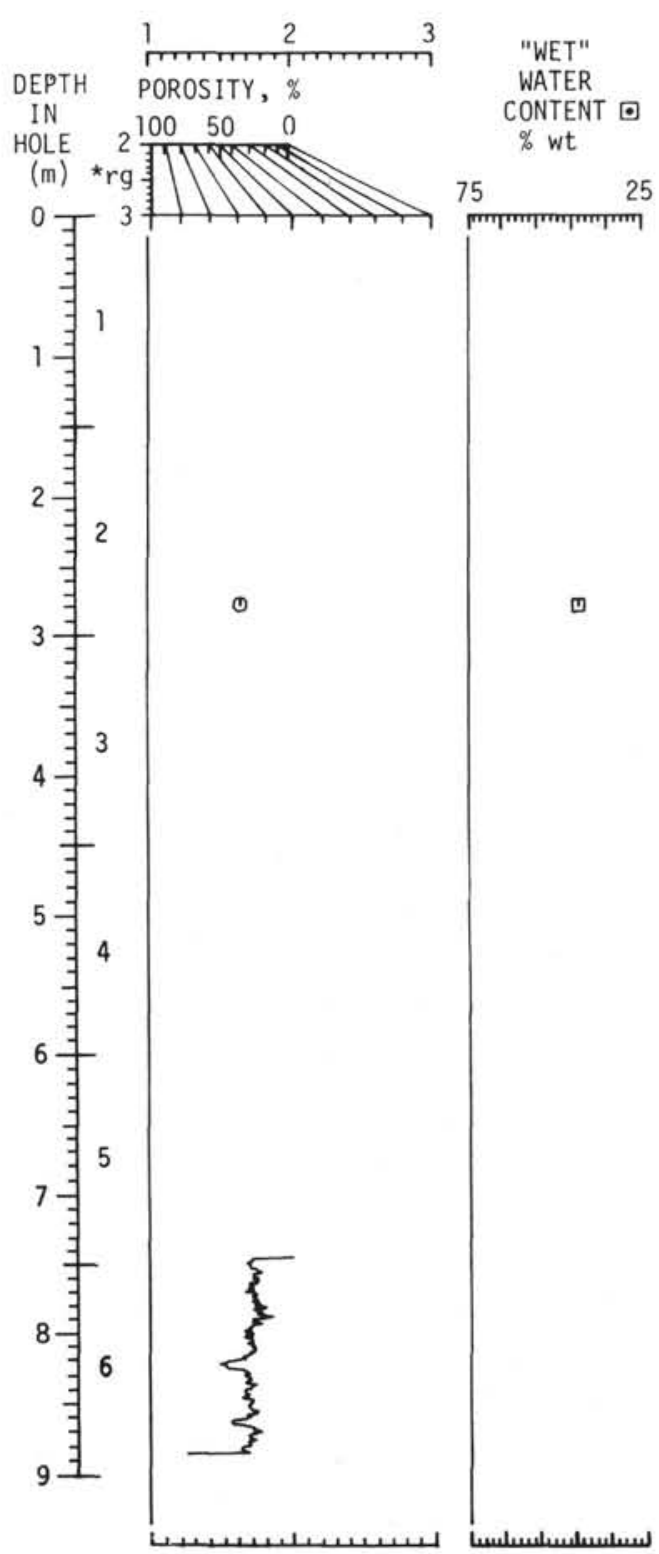

= Perpendicular To Bedding Bedding

$\begin{array}{llll}2 & 3 & 4 & 5\end{array}$

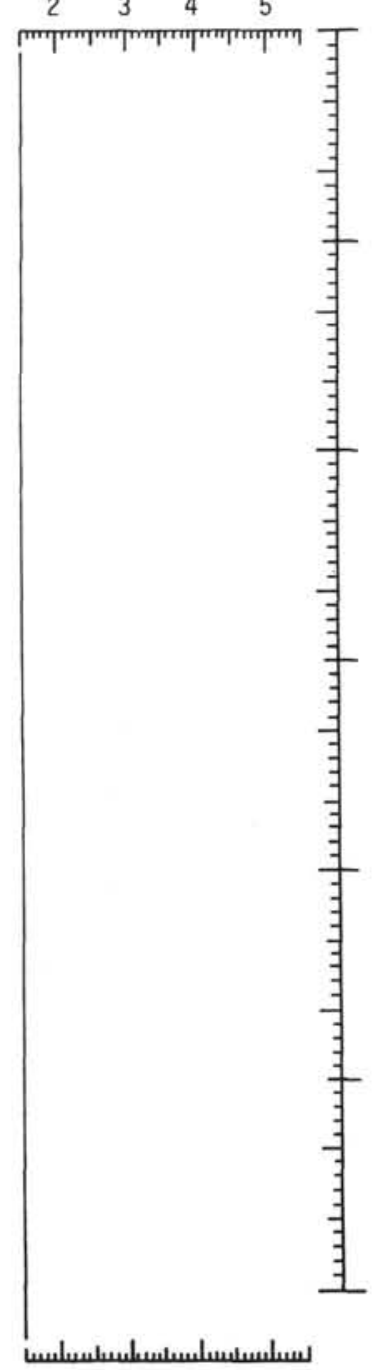

CORE 306-6

- $=$ GRAPE WET - BULK DENSITY, $\mathrm{g} / \mathrm{cc}$

๑ Syringe porosity, \% COMPRESSIONAL SOUND VELOCITY

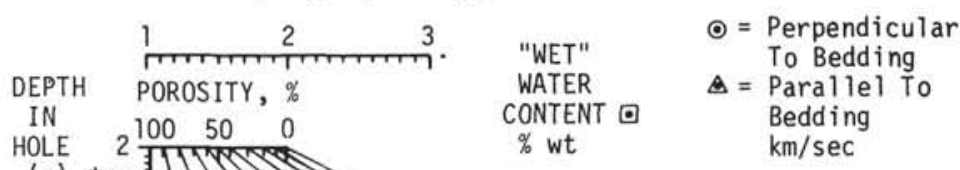

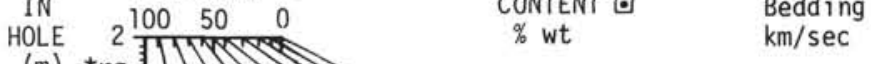

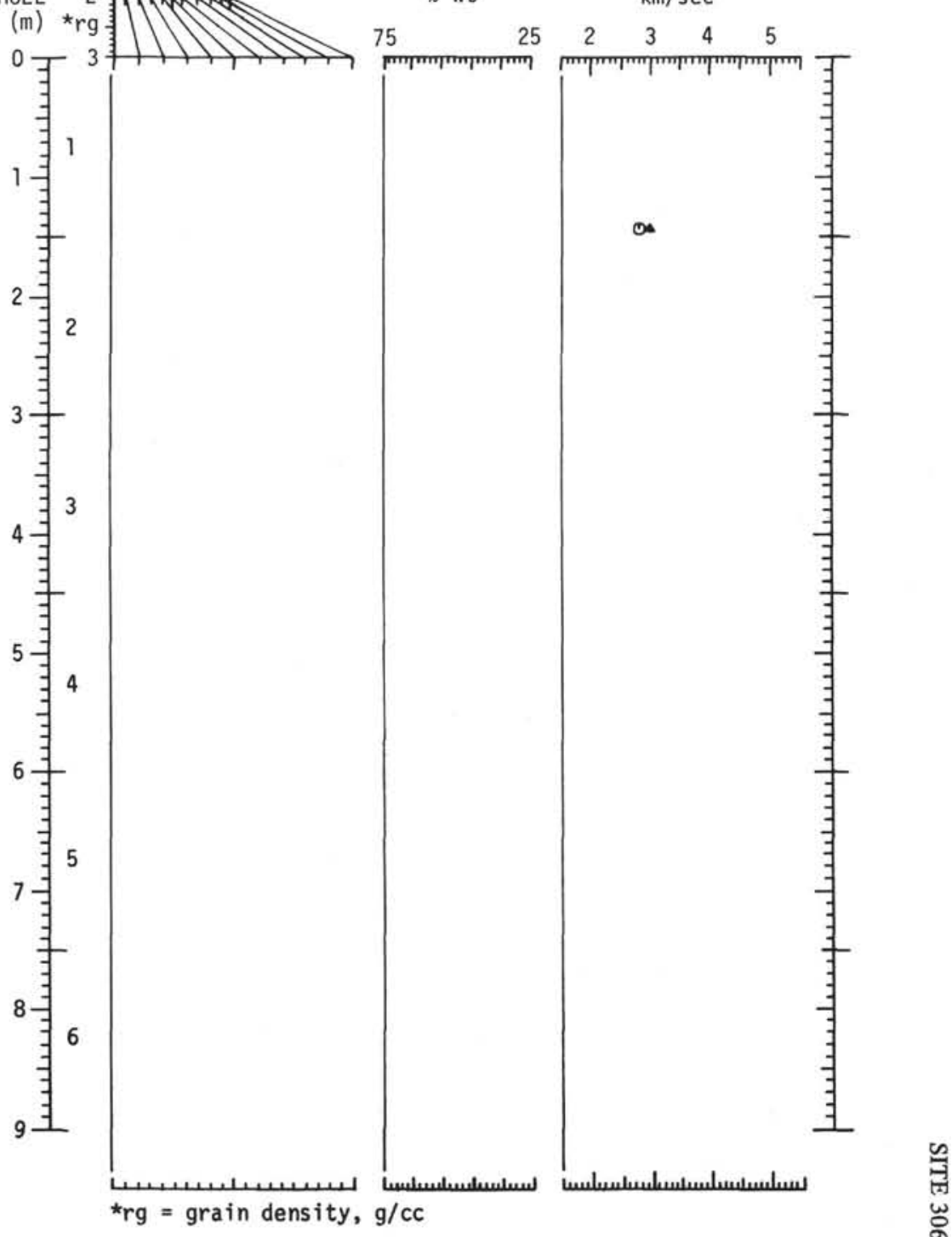


- $=$ GRAPE WET-BULK DENSITY, g/CC

- Syringe porosity, \% COMPRESSIONAL SOUND VELOCITY

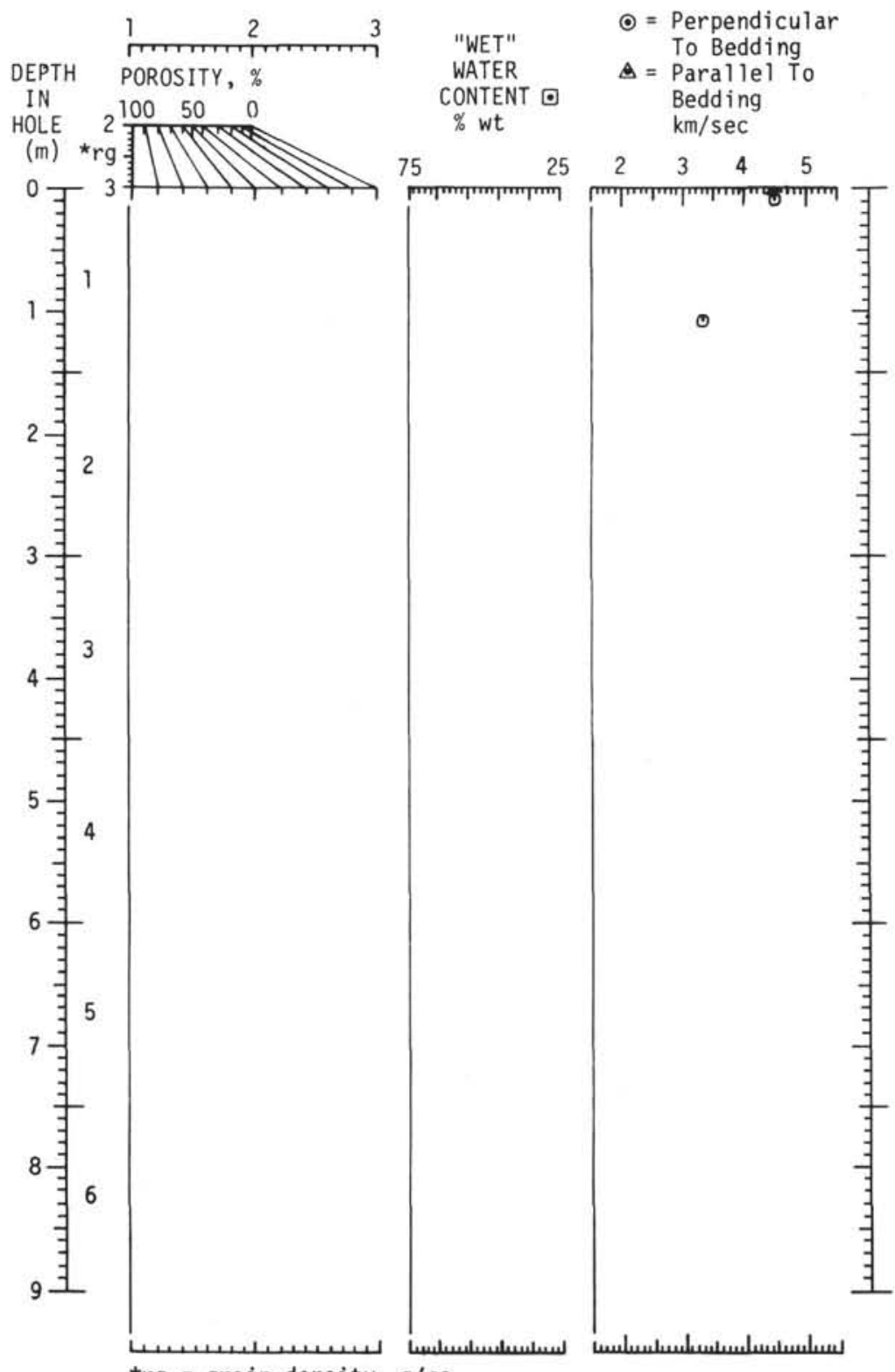

${ }^{*} \mathrm{rg}=$ grain density, $g / c c$
- $=$ GRAPE WET-BULK DENSITY, g/cc

- Syringe porosity, \% COMPRESSIONAL SOUND VELOCITY

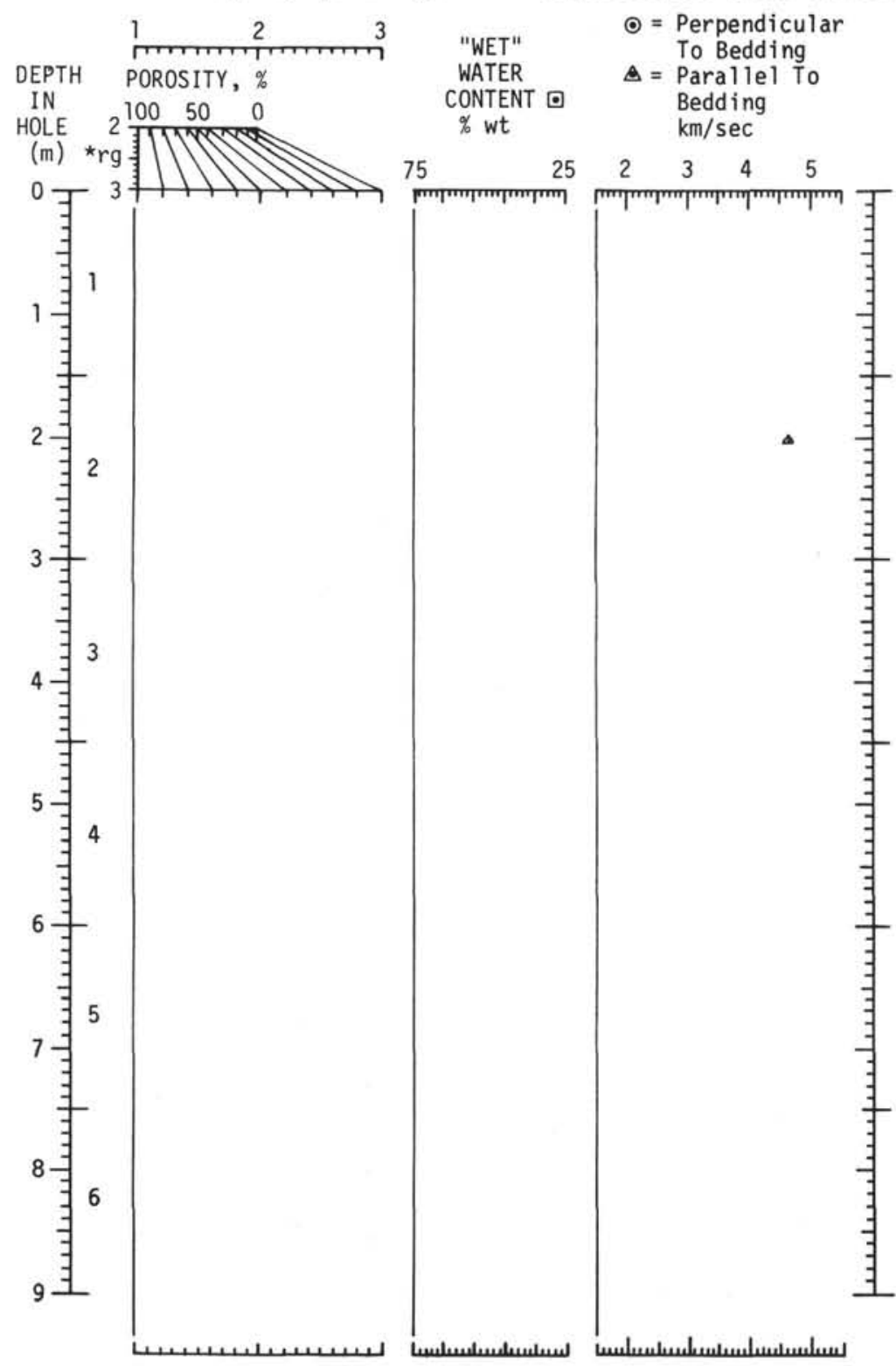

${ }^{*}$ rg $=$ grain density, $\mathrm{g} / \mathrm{cc}$ 
CORE 306-10

- $=$ GRAPE WET-BULK DENSITY, $g / c C$

○ Syringe porosity, \% COMPRESSIONAL SOUND VELOCITY

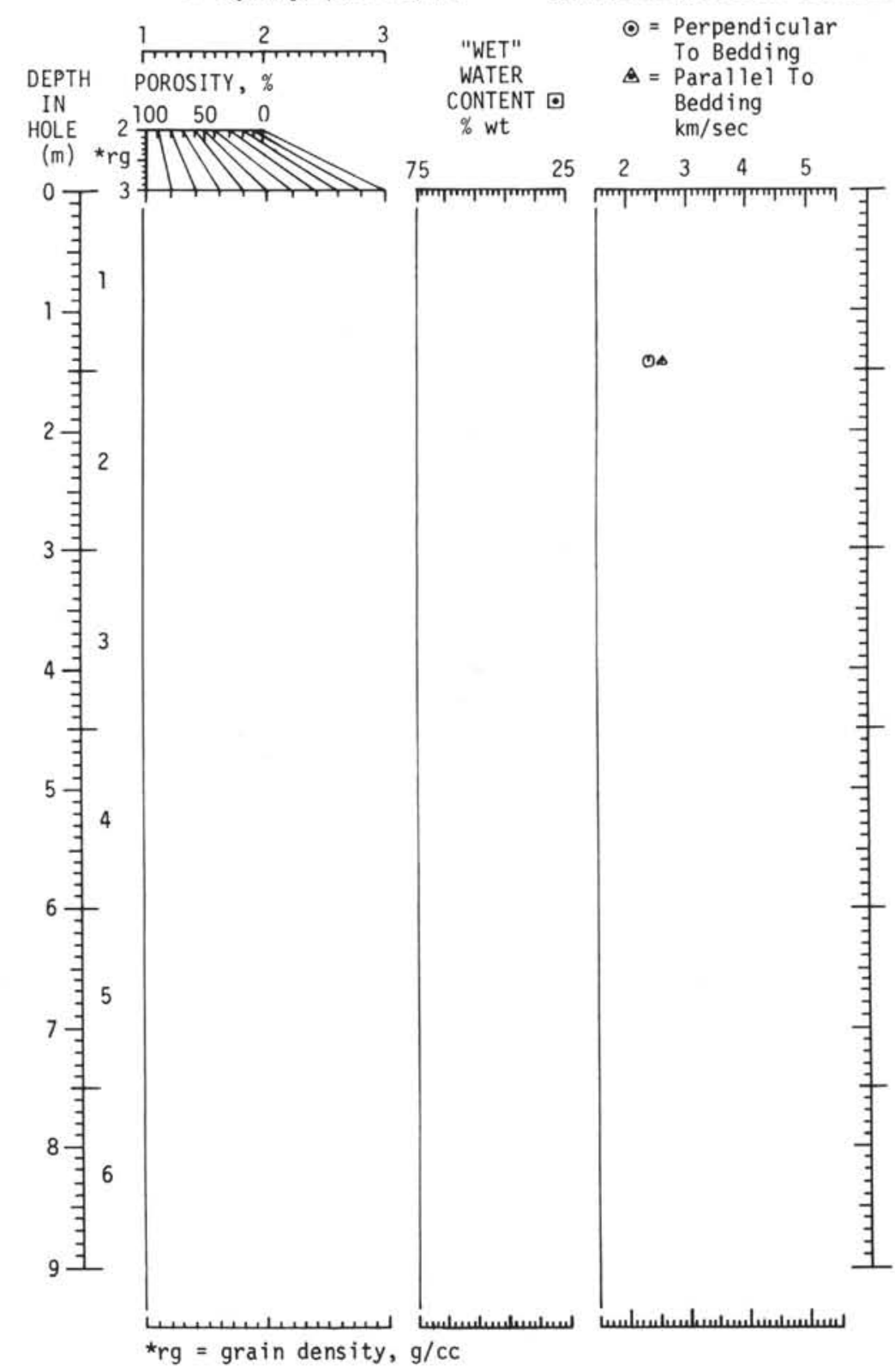

CORE 306-11

- $=$ GRAPE WET-BULK DENSITY, g/cc

- Syringe porosity, $\%$ COMPRESSIONAL SOUND VELOCITY

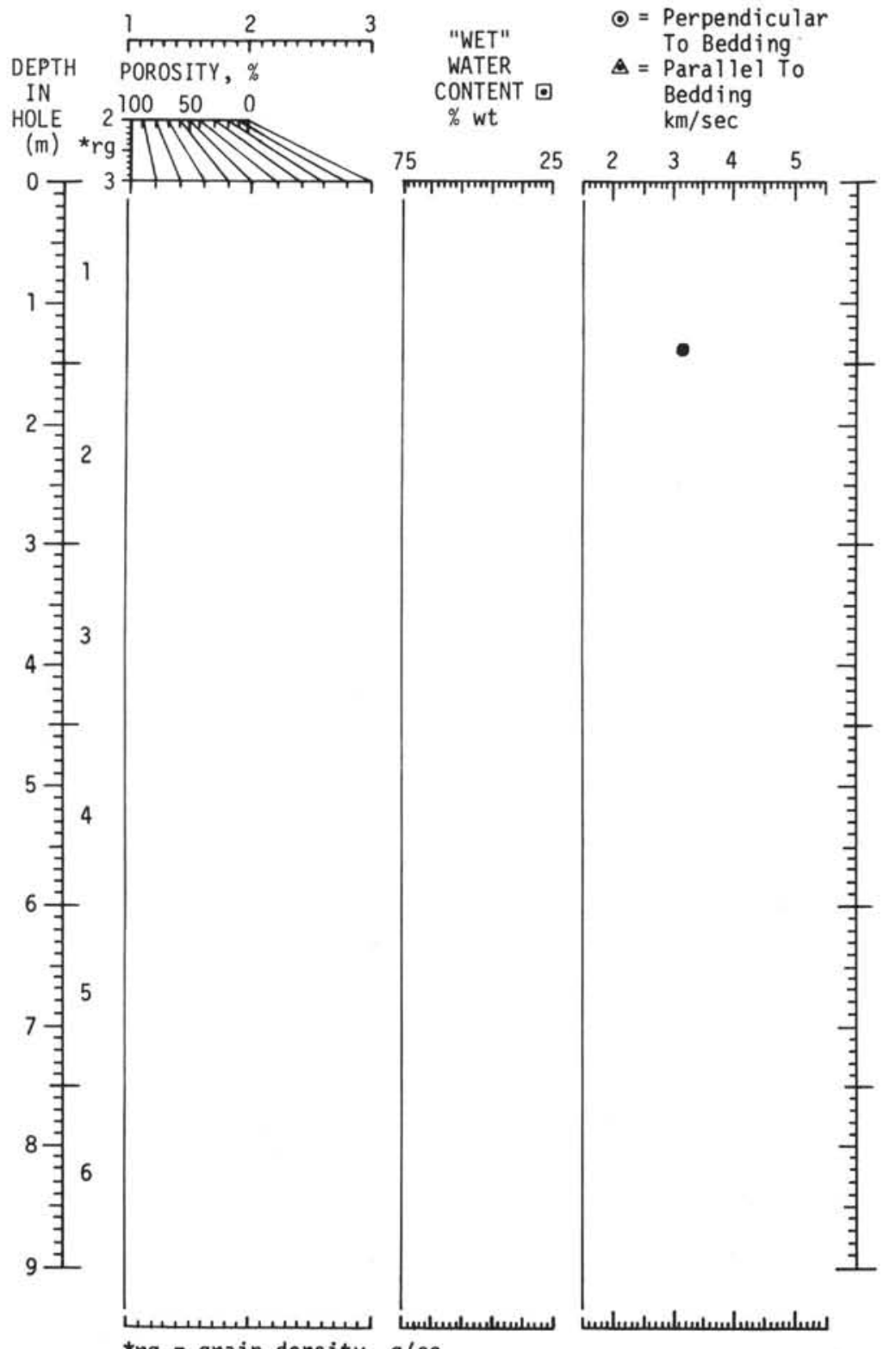


๑ Syringe porosity, \% COMPRESSIONAL SOUND VELOCITY

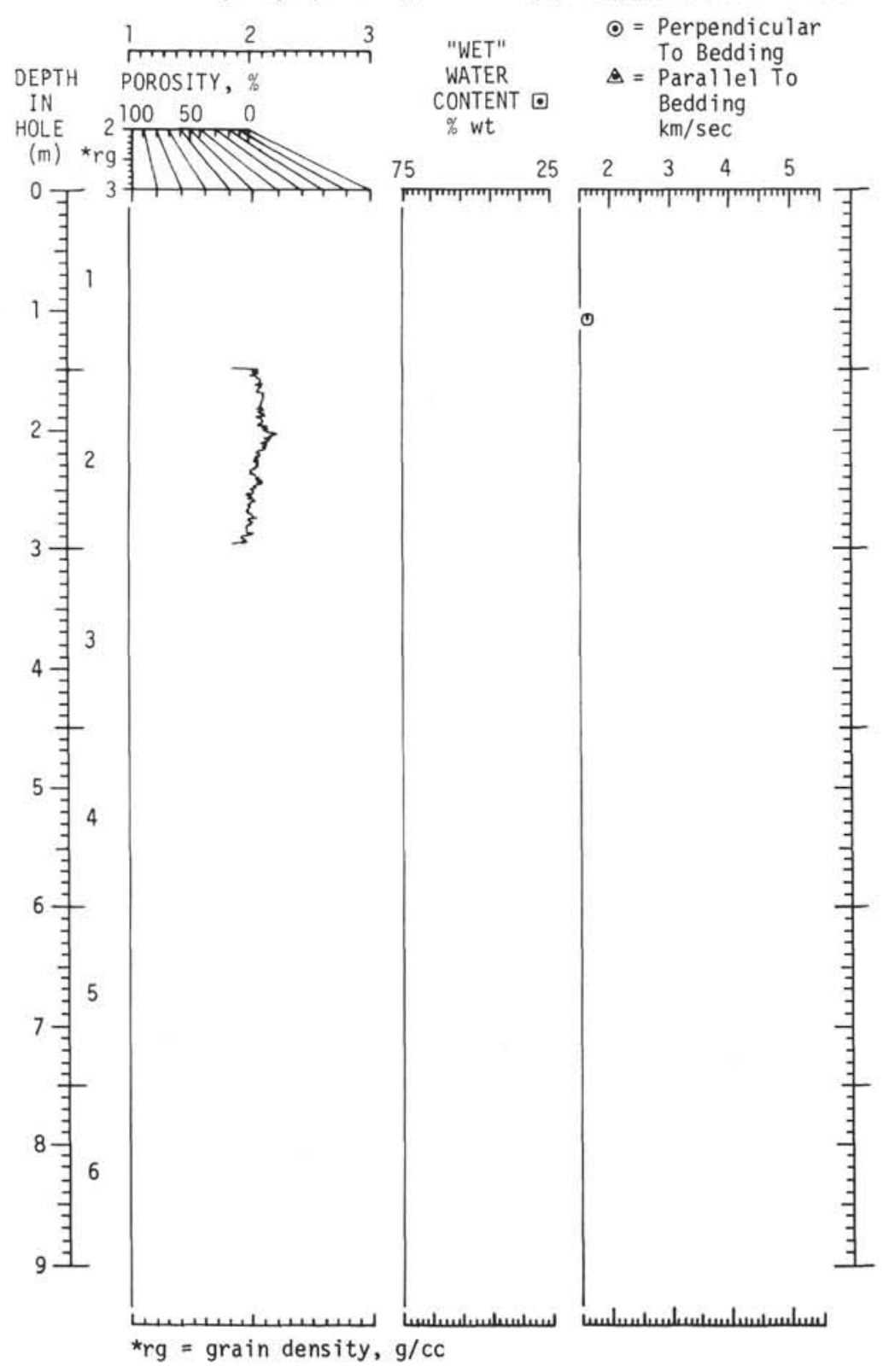

$=$ GRAPE WET-BULK DENSITY, $g / c C$

○ Syringe porosity, \%

COMPRESSIONAL SOUND VELOCITY

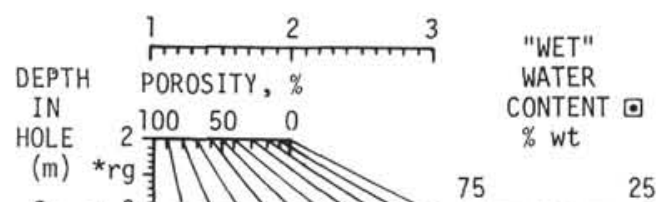

$\odot=$ Perpendicular To Bedding

$A=$ Parallel To Bedding

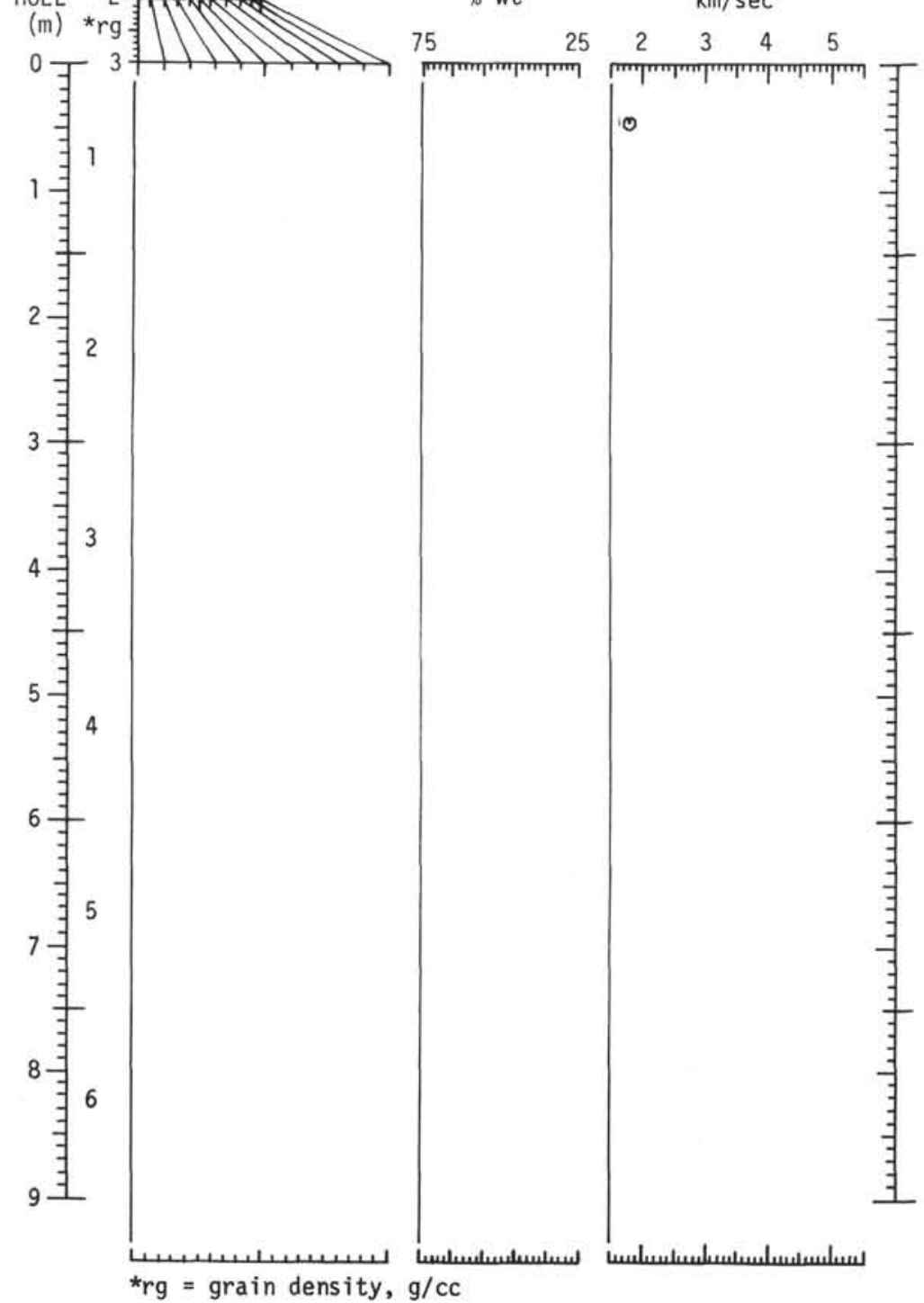


CORE 306-33

- = GRAPE WET-BULK DENSITY, $g / c c$

- Syringe porosity, \% COMPRESSIONAL SOUND VELOCITY

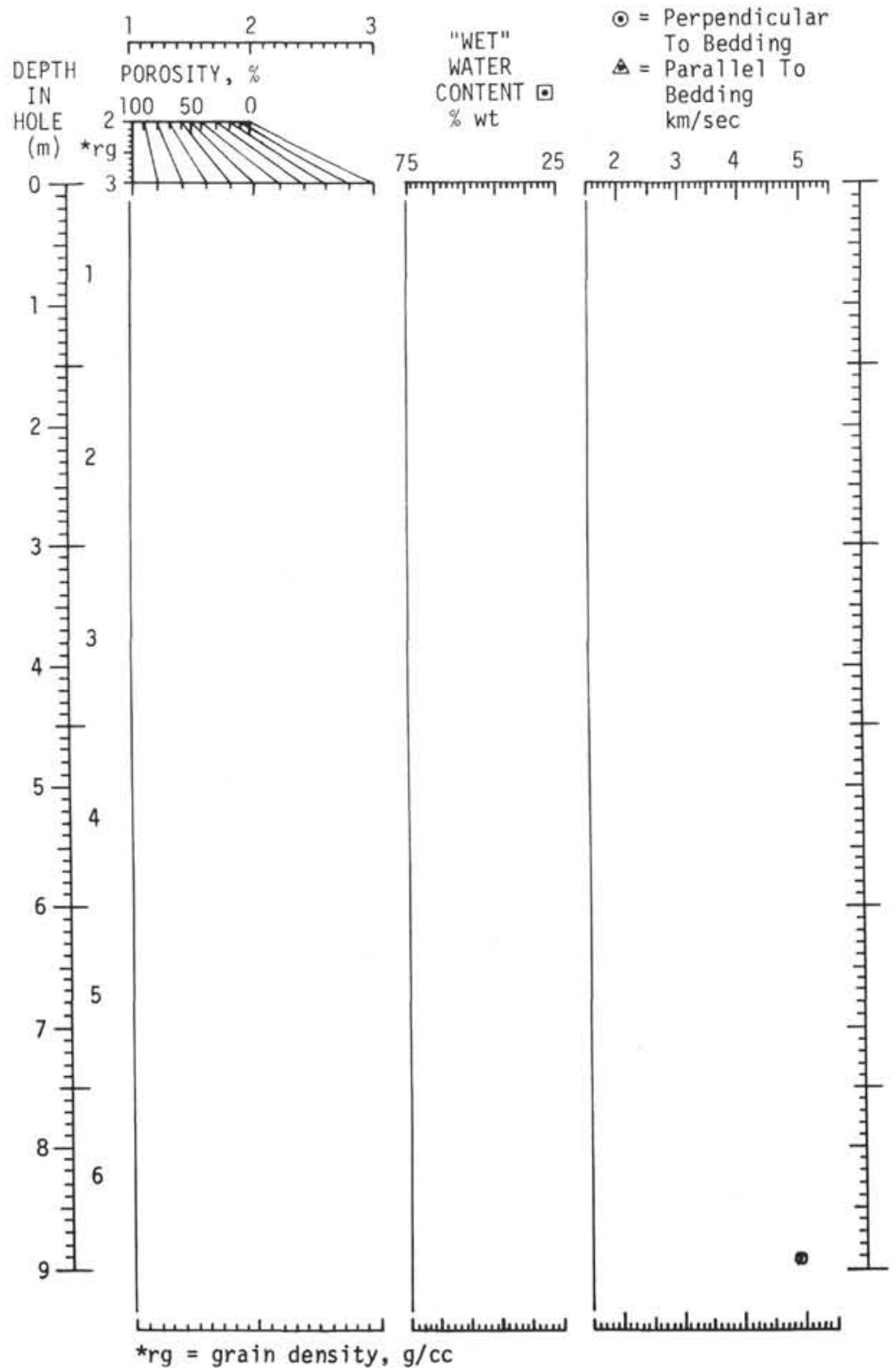

CORE 306-35

- $=$ GRAPE WET-BULK DENSITY, $\mathrm{g} / \mathrm{cc}$

○ Syringe porosity, \%

COMPRESSIONAL SOUND VELOCITY

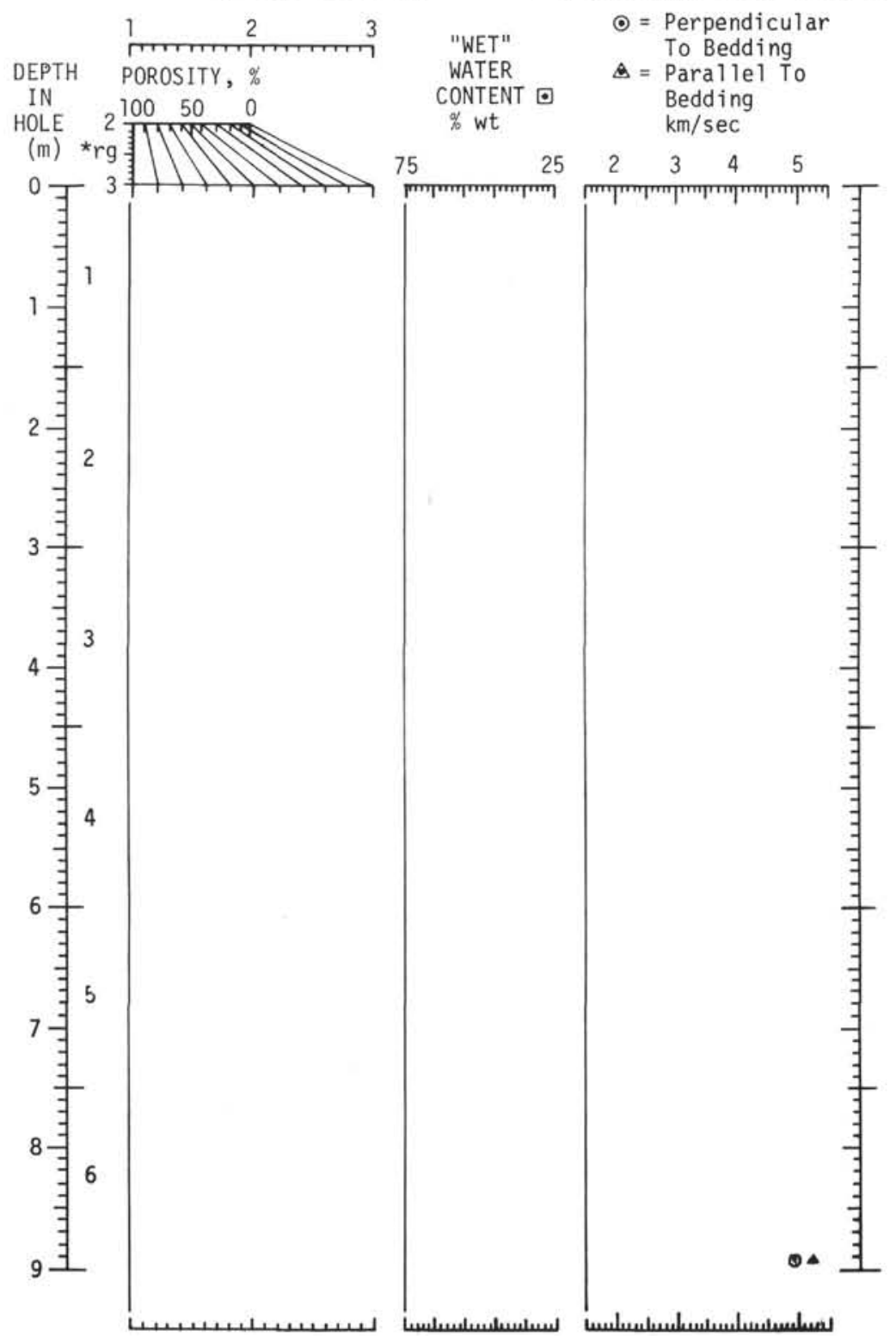

${ }^{*}$ rg $=$ grain density, g/cc 
- Syringe porosity, \% COMPRESSIONAL SOUND VELOCITY

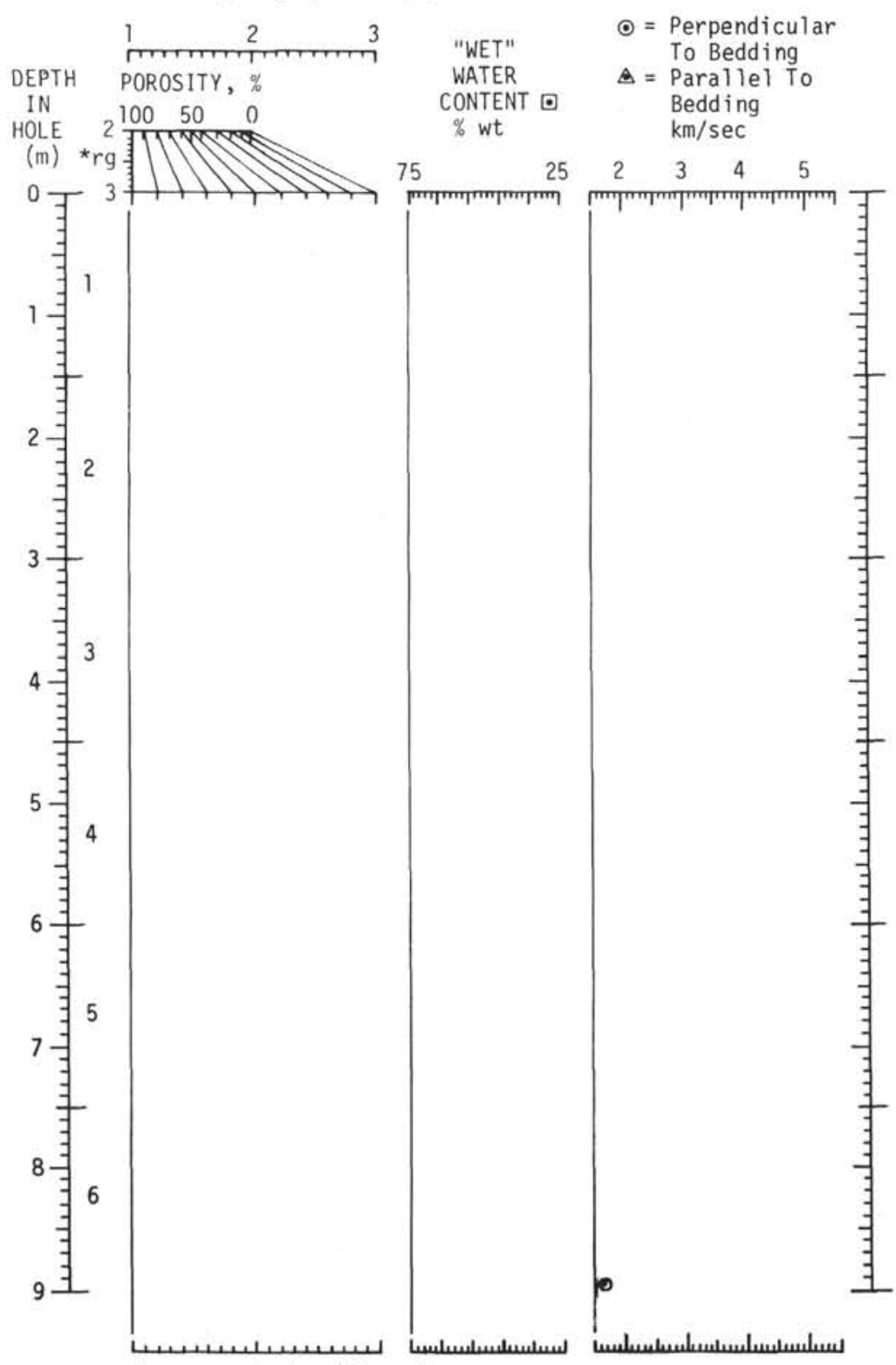

- Syringe porosity, \% COMPRESSIONAL SOUND VELOCITY

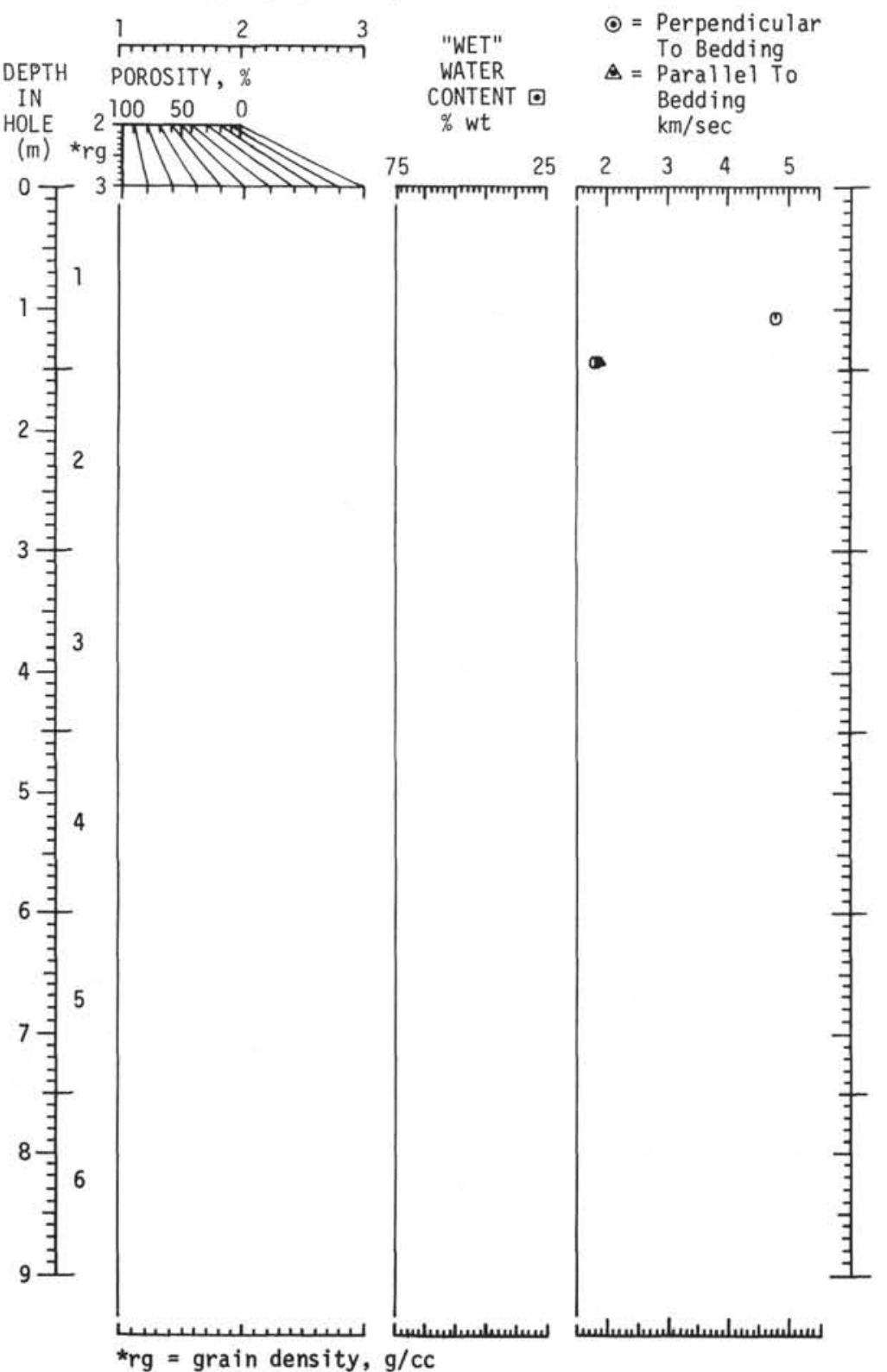


CORE $306-41$

- = GRAPE WET-BULK DENSITY, g/cC

๑ Syringe porosity, \% COMPRESSIONAL SOUND VELOCITY

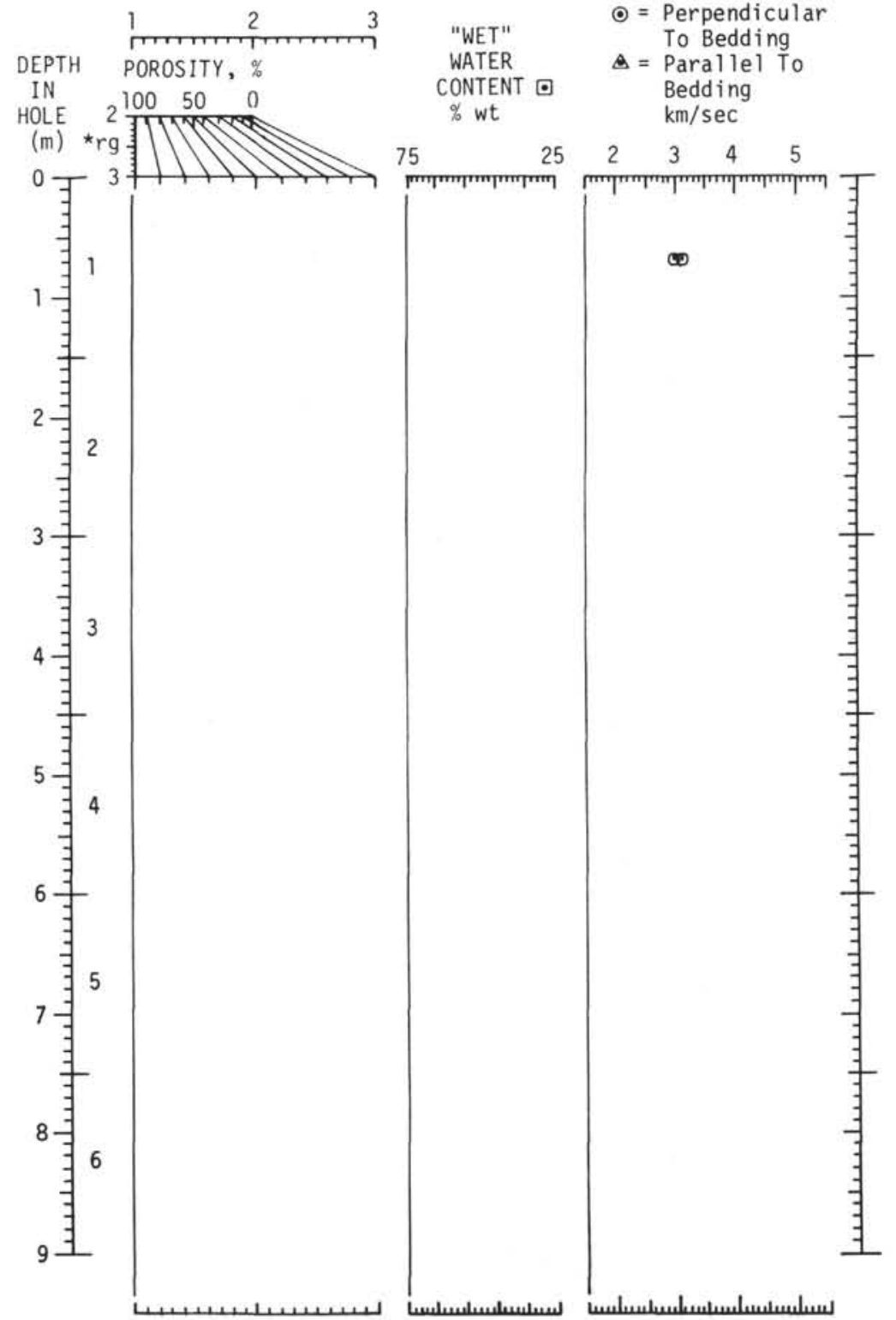




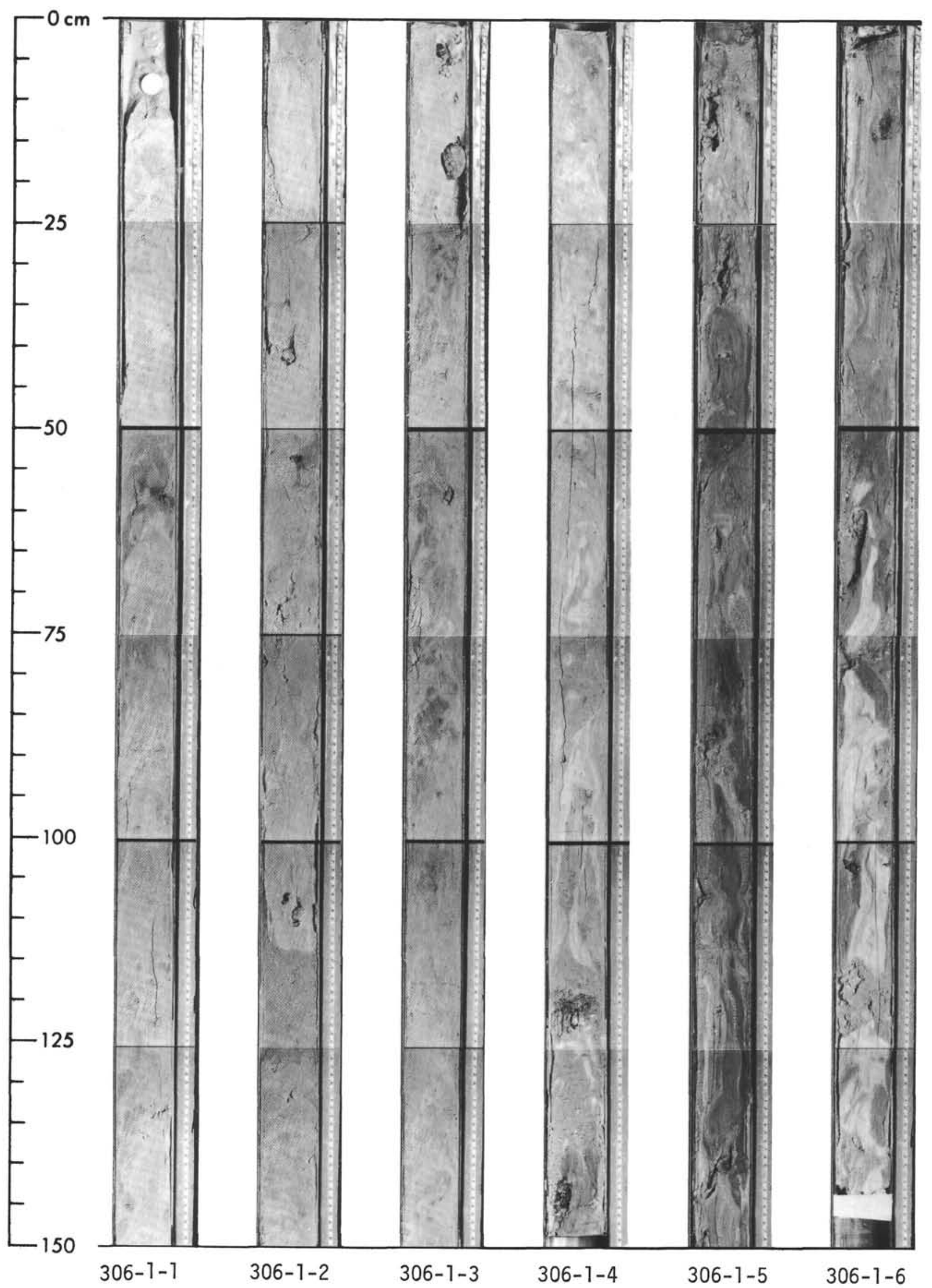




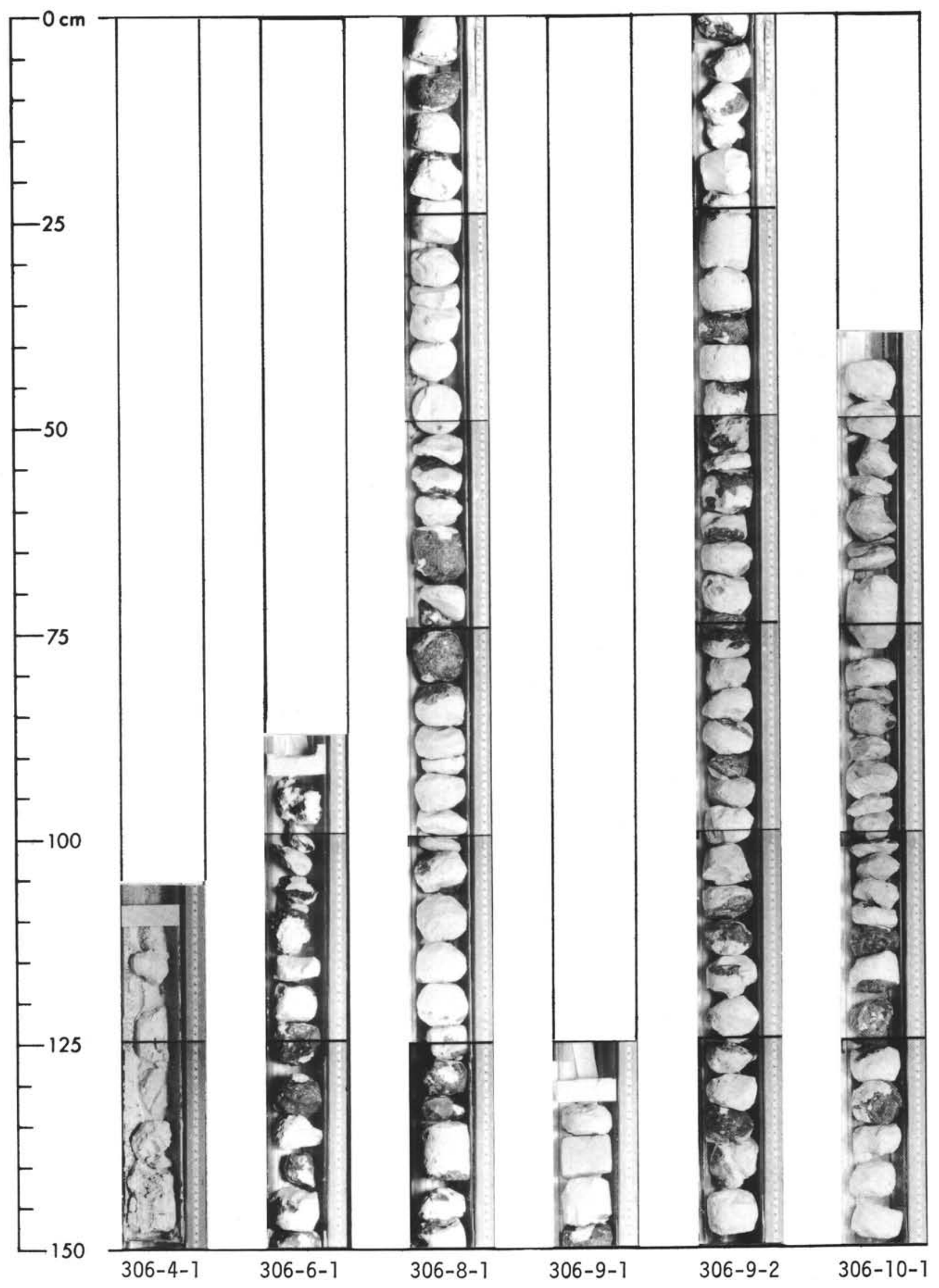




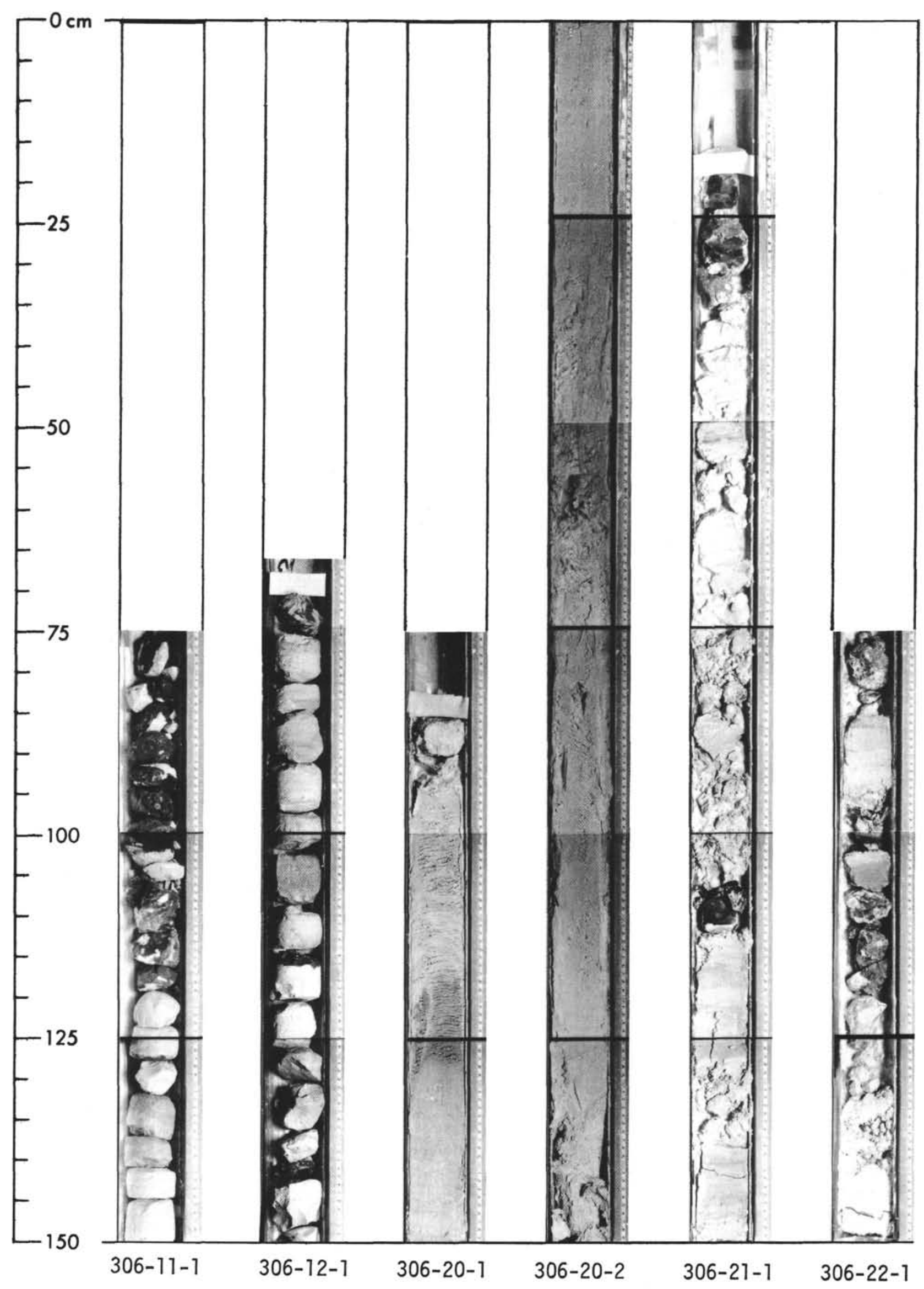




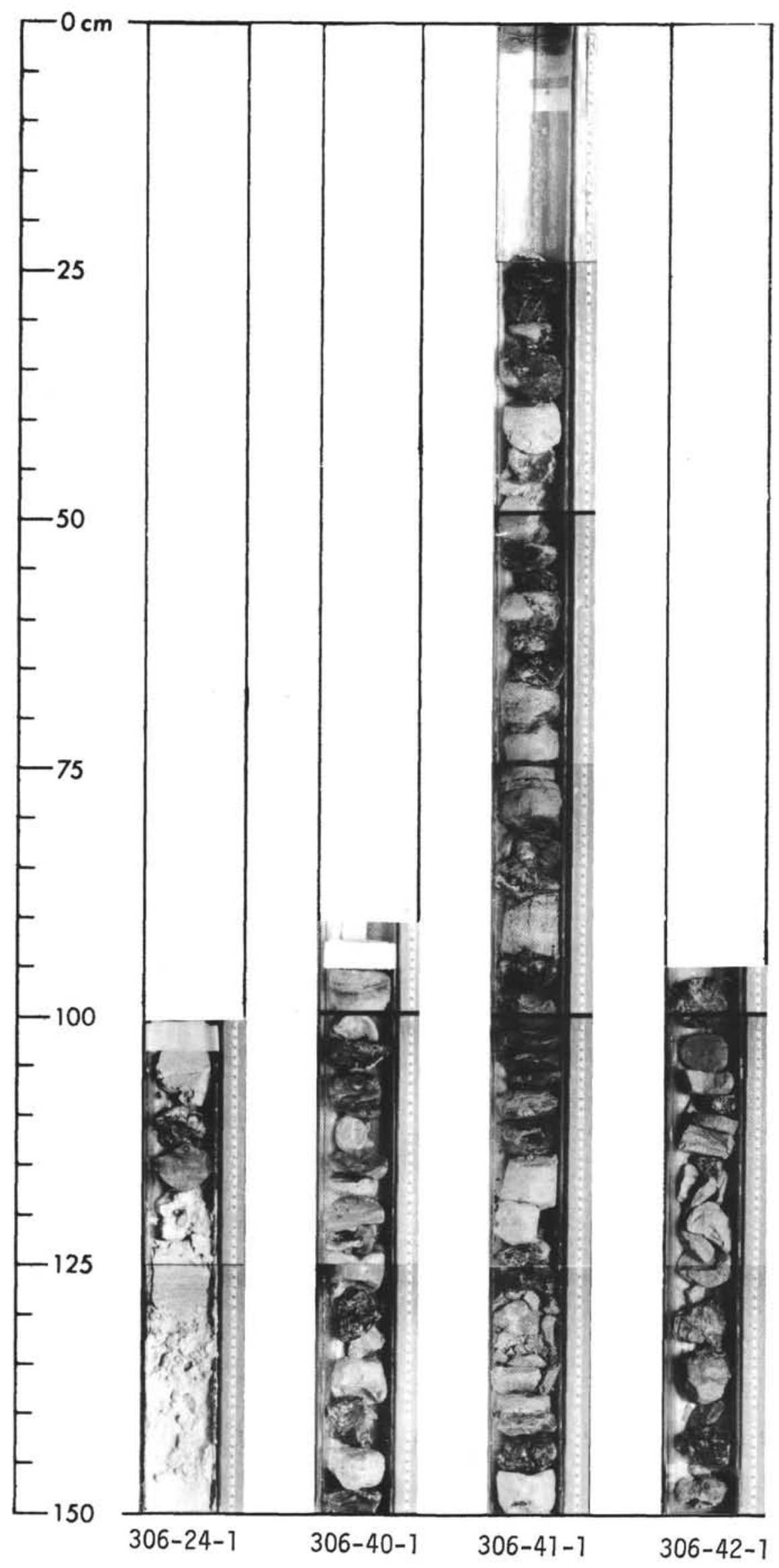

